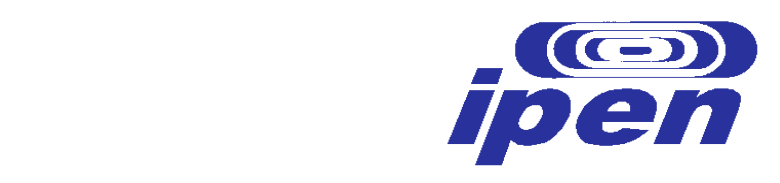

INSTITUTO DE PESQUISAS ENERGÉTICAS E NUCLEARES

Autarquia associada à Universidade de São Paulo

\title{
ESTUDO DE MATERIAIS ALTERNATIVOS PARA APLICAÇÃO EM SISTEMAS DE PRÓTESES ODONTOLÓGICAS COM CONEXÕES MAGNÉTICAS
}

ROGÉRIO ALBUQUERQUE MARQUES

Dissertação apresentada como parte dos requisitos para obtenção do Grau de Mestre em Ciências na Área de Tecnologia Nuclear - Materiais.

Orientador: Dr. Adonis Marcelo Saliba-Silva

São Paulo 


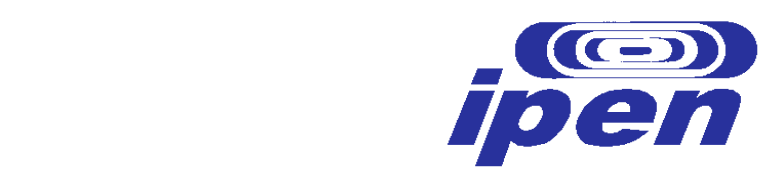

INSTITUTO DE PESQUISAS ENERGÉTICAS E NUCLEARES

Autarquia associada à Universidade de São Paulo

ESTUDO DE MATERIAIS ALTERNATIVOS PARA APLICAÇÃO EM SISTEMAS DE PRÓTESES ODONTOLÓGICAS COM CONEXÕES MAGNÉTICAS

ROGÉRIO ALBUQUERQUE MARQUES

Dissertação apresentada como parte dos requisitos para obtenção do Grau de Mestre em Ciências na Área de Tecnologia Nuclear - Materiais.

Orientador: Dr. Adonis Marcelo Saliba-Silva

São Paulo 
"A coisa mais indispensável a um homem é reconhecer o uso que deve fazer do seu próprio conhecimento."

Platão 


\section{AGRADECIMENTOS}

Agradeço a Deus pelo maravilhoso dom da vida e a oportunidade de poder continuar desfrutando-a com saúde.

Ao Prof. Dr. Adonis Marcelo Saliba-Silva pela orientação, amizade e incentivo para que este trabalho fosse feito.

À Prof. Dra. Isolda Costa pela amizade e apoio em todos os momentos desta dissertação. Por todas as sugestões dadas a este trabalho e todas as respostas às minhas dúvidas.

À minha companheira Janaina pela paciência, incentivo e apoio, que foram fundamentais para que eu continuasse meus estudos.

Aos meus pais, Cleuza e Wanderley, pela dedicação durante todos os anos da minha vida.

Aos amigos Dr. Everson do Prado Banczek e Dra. Maysa Terada pela ajuda nos ensaios de laboratório e infindáveis explicações sobre os conceitos teóricos. Vocês foram imprescindíveis para a finalização deste trabalho.

Aos amigos Olandir V. Correa, Dr. Renato Altobelli Antunes pelas valiosas discussões, auxílio nos experimentos e apoio nas horas complicadas.

Ao IPEN pela oportunidade de desenvolvimento deste trabalho.

À Prof. Dra. Sizue O. Rogero pela colaboração com as análises de citotoxicidade.

À Prof. Dra. Maria de Fátima Montemor pelas análises por XPS.

Às empresas Plansee e Sandvik pelas amostras fornecidas.

$\mathrm{E}$ a todas as outras pessoas não citadas aqui, mas que de uma maneira singela contribuíram para esta jornada. 


\title{
ESTUDO DE MATERIAIS ALTERNATIVOS PARA APLICAÇÃO EM SISTEMAS DE PRÓTESES ODONTOLÓGICAS COM CONEXÕES MAGNÉTICAS
}

\author{
Rogério Albuquerque Marques
}

\begin{abstract}
RESUMO
Materiais ferromagnéticos são investigados como possíveis candidatos para aplicações em próteses dentais em substituição aos conectores magnéticos feitos em ligas ferromagnéticas de elevado custo. Neste trabalho, três materiais foram investigados: o aço inoxidável 17-4 PH, confeccionado por moldagem de pós por injeção (PIM), a liga PM2000, obtida por "mechanical alloying" e endurecida por dispersão de óxidos, e o aço inoxidável 1802, isento de níquel. O ensaio de citotoxicidade in vitro mostrou que nenhum dos três materiais era citotóxico. $\mathrm{O}$ comportamento frente à corrosão foi estudado através de curvas de polarização anódica potenciodinâmicas e por espectroscopia de impedância eletroquímica (EIE) em solução tamponada com fosfato (PBS), a $25^{\circ} \mathrm{C}$. Como material de referência, foi utilizado o aço inoxidável $316 \mathrm{~L}$ devido ao seu amplo emprego como biomaterial, principalmente na confecção de próteses ortopédicas. Todos os materiais se mostraram passivos em condições estacionárias, mas apresentaram tendência à corrosão por pite. O que apresentou maior resistência à corrosão por pite foi o PM2000, enquanto o aço 1802 mostrou a maior susceptibilidade a este tipo de corrosão, entre os estudados. Os diagramas de Mott-Schottky indicaram que o filme passivo superficial do aço PM2000 é pelo menos uma ordem de grandeza menos dopado que o filme do aço $316 \mathrm{~L}$ e, portanto, menos defeituoso. Os resultados apontaram para o PM2000 como um possível candidato para a substituição das ligas nobres ferromagnéticas de alto custo.
\end{abstract}




\title{
ALTERNATIVE MATERIALS STUDY FOR DENTAL MAGNETICS ATTACHMENTS APLICATIONS
}

\author{
Rogério Albuquerque Marques
}

\begin{abstract}
Ferromagnetic alloys have been investigated as potential candidates for dental prosthesis applications in replacement for magnetic attachments made of noble and expensive alloys. Three stainless steels were investigated: 17-4 PH produced by powder injection (PIM), PM2000 obtained by mechanical alloying and oxide dispersion strengthened, and nickel free stainless steel 1802. In the in vitro cytotoxicity analysis, none of the three steels tested showed cytotoxic effects. The corrosion resistance of stainless steels was evaluated by electrochemical impedance spectroscopy (EIS) and anodic potentiodynamic polarization, in sodium phosphate buffer solutions (PBS) at $25^{\circ} \mathrm{C}$. The AISI $316 \mathrm{~L}$ stainless steel was also tested under the same conditions for comparison reasons. All the stainless steel samples were passive in the electrolyte used and presented susceptibility to pitting. The steel that showed the highest pitting resistance was the PM2000, whereas the 1802 had the lowest resistance to pitting among the tested ones. The Mott-Schottky diagrams suggested that the passive film over the surface of PM2000 steel is at least one decade less doped compared to $316 \mathrm{~L}$ stainless steel, so less defective in its structure. The results pointed out to the PM2000 as a potential candidate for substitution of high cost magnetic alloys used in dental prosthesis.
\end{abstract}


1. INTRODUÇÃO

2. OBJETIVOS

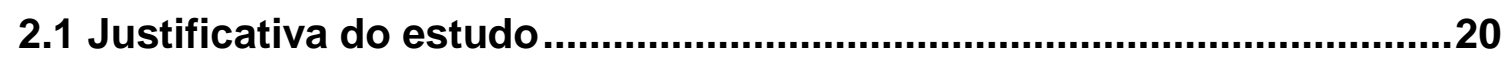

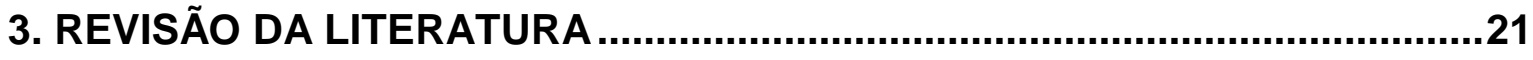

3.1 Aplicações clínicas do sistema de fixação magnética para próteses

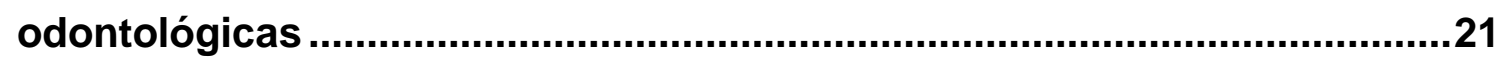

3.1.1 Pacientes portadores de marcapasso cardíaco....................................22

3.1.2 Imagem por Ressonância Magnética (IRM) ......................................22

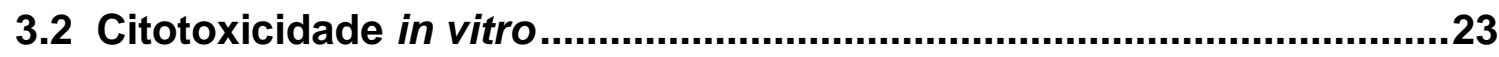

3.3 Corrosão de aços inoxidáveis e técnicas eletroquímicas .....................24

3.3.1 Circuitos Elétricos Equivalentes (CEE) ........................................27

3.3.2 Propriedades eletrônicas do filme passivo - Técnica de Mott-Schottky.29

3.4 Ligas metálicas selecionados para este estudo .......................................32

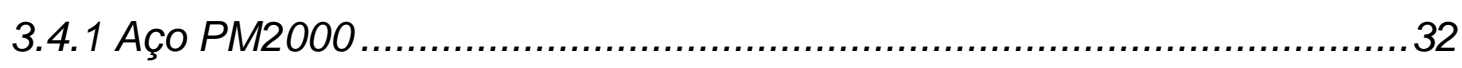

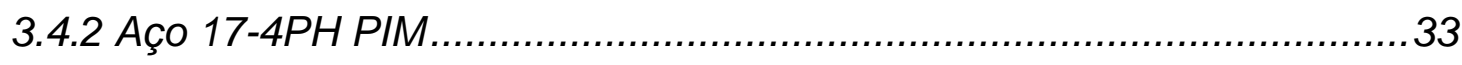

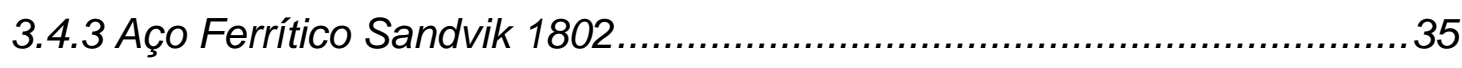

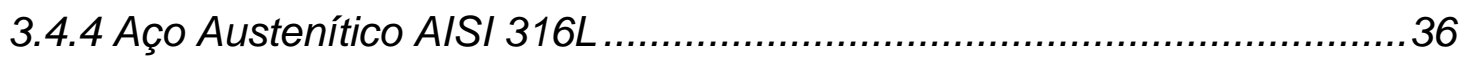

3.5 Espectroscopia Fotoelétrica por Raio-X (XPS) …....................................37

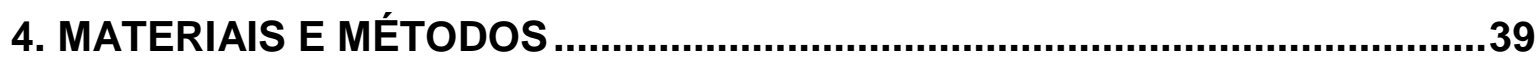

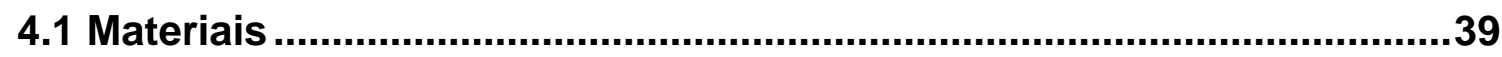

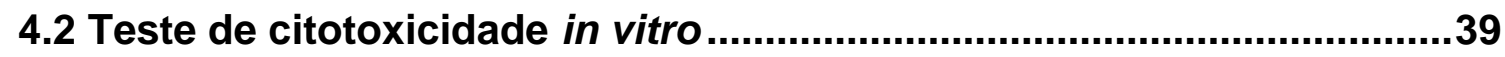

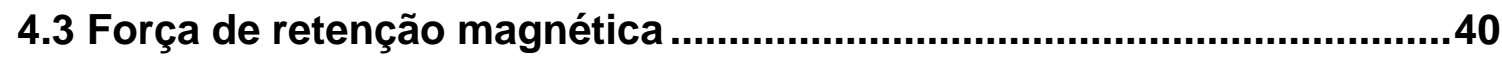

4.4 Ensaios eletroquímicos ..............................................................................41

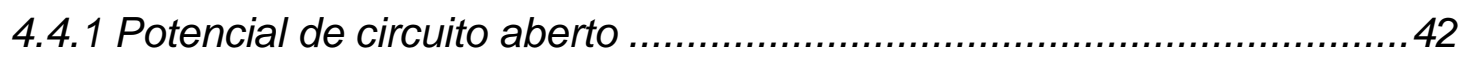

4.4.2 Espectroscopia de Impedância Eletroquímica (EIE)............................43 
4.4.3 Polarização anódica potenciodinâmica..................................................43

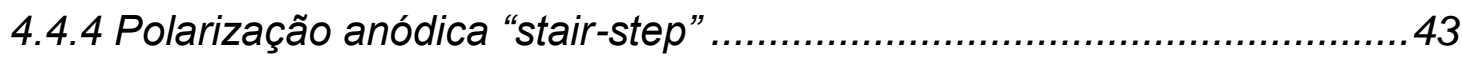

4.4.5 Gráficos de Mott-Schottky - Propriedades eletrônicas do filme passivo44 4.4.6 Análise da composição química superficial por XPS ............................44

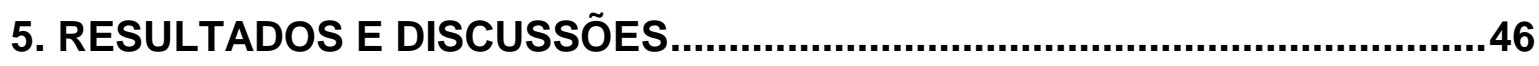

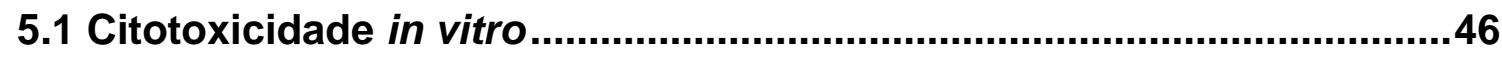

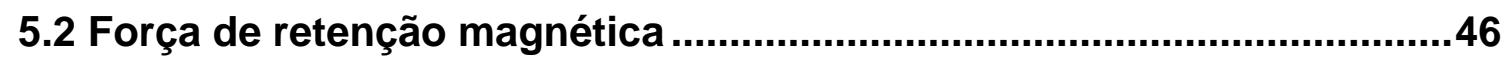

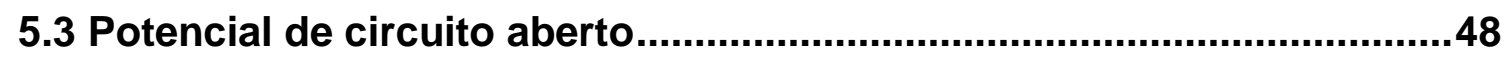

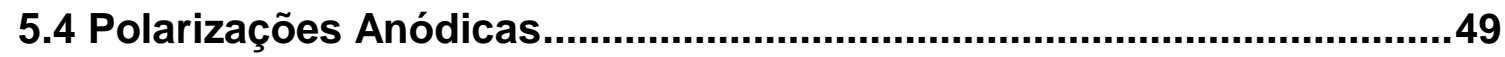

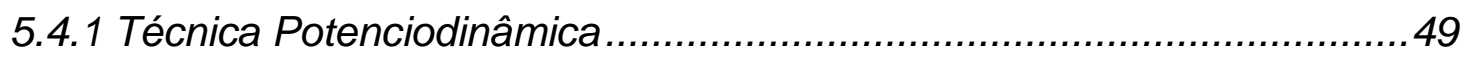

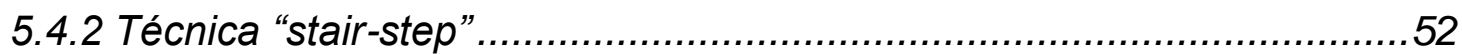

5.4.3 Técnica Stair-Step versus Técnica Potenciodinâmica ...........................56

5.5 Ensaios de Espectroscopia de Impedância Eletroquímica (EIE) ...........57

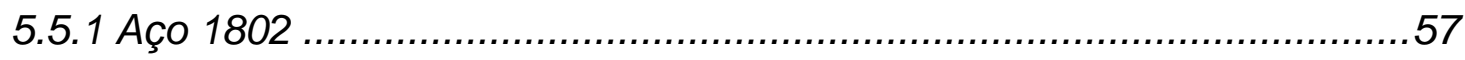

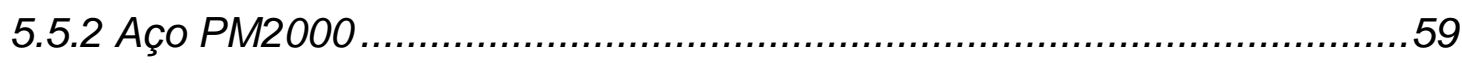

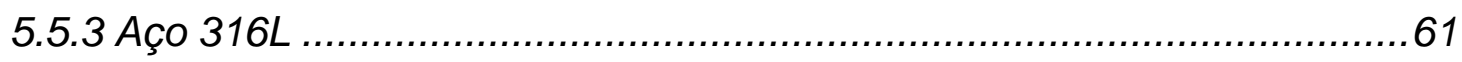

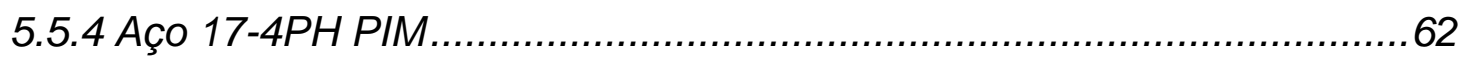

5.5.5 Comparação entre os quatro aços avaliados ......................................64

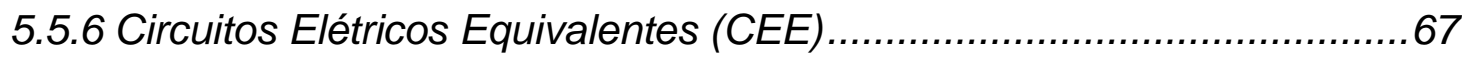

5.5.6.1 Comparativo dos valores obtidos do ajuste dos resultados experimentais ao CEE proposto para 2 dias de imersão............................71

5.5.6.2 Comparativo dos valores obtidos do ajuste dos resultados experimentais ao CEE proposto para 21 dias de imersão...........................71

5.6 Propriedades Eletrônicas do Filme Passivo - Gráficos de Mott-

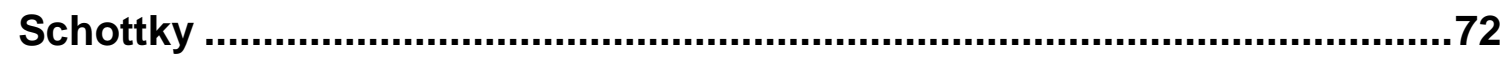

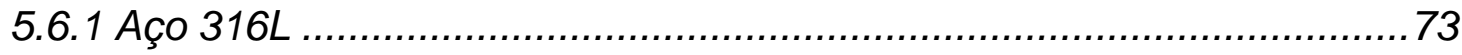

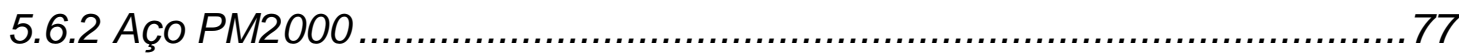

5.6.3 Comparativo entre os diagramas de Mott-Schottky dos aços 316L e

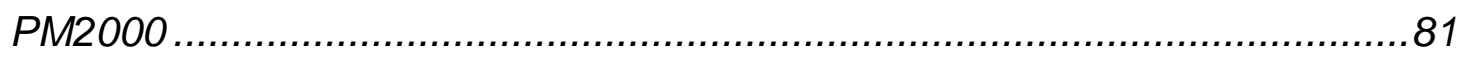

5.7 Análise da composição química superficial do aço PM2000 por XPS..84 
6. CONCLUSÕES

7. SUGESTÕES PARA TRABALHOS FUTUROS .............................................. 89

REFERÊNCIAS BIBLIOGRÁFICAS...............................................................90

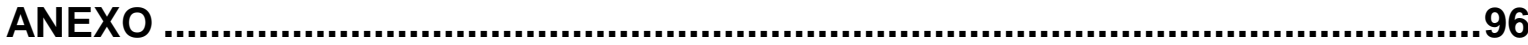




\section{LISTA DE TABELAS}

Página

Tabela 1 - Composição química dos aços utilizados (\% em massa) por Takada et al . 27

Tabela 2 - Resistência à corrosão do aço Sandvik 1802 comparado com o aço AISI 316L em diferentes meios.

Tabela 3 - Composição química (\% em massa) dos aços utilizados neste estudo.

Tabela 4 - Composição química da solução salina tamponada com fosfato (\% em massa).

Tabela 5 - Potenciais de circuito aberto dos aços ensaiados, após estabilização.

Tabela 6 - Potenciais de corrosão, de pite e densidade de corrente de corrosão dos aços PM2000, 1802, 17-4PH PIM e 316L.

Tabela 7 - Potenciais de corrosão, de pite e densidade de corrente de corrosão dos aços PM2000, 1802, 17-4PH PIM e 316L. .54

Tabela 8 - Potenciais de pite $\left(E_{\mathrm{p}}\right)$ e densidades de corrente de corrosão $\left(i_{\text {corr }}\right)$ dos aços inoxidáveis PM2000, 1802, 17-4PH PIM e 316L, obtidos dos resultados das técnicas de polarização anódica potenciodinâmica e polarização anódica "stair-step".

Tabela 9 - Valores ajustados dos diagramas de impedância pelos CEE, após 2 dias de imersão em meio PBS, naturalmente aerado à $25^{\circ} \mathrm{C}$ 69

Tabela 10 - Valores ajustados dos diagramas de impedância pelos CEE, após 21 dias de imersão em meio PBS, naturalmente aerado à $25^{\circ} \mathrm{C}$ 69 


\section{LISTA DE FIGURAS}

Página

Figura 1 - Sistema magnético sobre implante. A) Imã; B) Conector protético; C) Implante. Fonte: Dyna Magnet Manual 16

Figura 2 - Incidência das forças laterais sobre um sistema rígido e sobre um sistema magnético.

Figura 3 - Prótese parcial removível utilizando sistema imã-dente. A) Conectores protéticos (núcleos) sobre raízes. B) Imãs fixados na prótese. Fonte: MIYAO et al. 2005 18

Figura 4 - Prótese total utilizando sistema imã-dente. A) Conectores protéticos (núcleos) sobre raízes. B) Imãs fixados na prótese. Fonte: MIYAO et al. 2005 18

Figura 5 - Prótese total (overdenture) utilizando sistema imã-implante. A) Conectores protéticos sobre implante. B) Imãs fixados na prótese. Fonte: MIYAO et al. 2005 18

Figura 6 - Prótese auricular sobre implantes com retenção magnética. Fonte: THOMAS, 1995. 19

Figura 7 - Circuitos elétricos equivalentes propostos para caracterizar a camada passiva dos aços inoxidáveis (AZUMl et al., 1986, BUNDY et al., 1993, MONTEMOR et al, 2000, LIU et al., 2003, ANTUNES, 2006, TERADA, 2008).

Figura 8 - Diagrama esquemático dos gráficos obtidos pelo método de MottSchottky. 30

Figura 9 - Microestrutura do aço PM2000 após recristalização. Fonte: FLORES et al 2004 .33

Figura 10 - Microestrutura do aço $17-4 \mathrm{PH}$ : A) produzido pela técnica de moldagem de pós por injeção (PIM); B) por metalurgia convencional. Ataque: Solução de Villela. Fonte: COSTA et al. (2004) .34

Figura 11 - Comparativo entre resistência à corrosão e propriedades magnéticas de diferentes aços. Fonte: General datasheet of precison wire 1802 - Sandvik

Figura 12 - Micrografia ótica da superfície do aço inoxidável 316L após ataque eletrolítico segundo procedimento 13b da norma ASTM E407-99. Fonte ANTUNES, 2006. 
Figura 13 - Desenho esquemático do aparato para medição comparativa da força de retenção magnética.

Figura 14 - Eletrodo de trabalho embutido em resina epóxi de cura a frio (Epofix) 42

Figura 15 - Célula eletroquímica com arranjo de três eletrodos. 42

Figura 16 - Analisador de respostas em freqüência Solartron 1260 (b) acoplado a

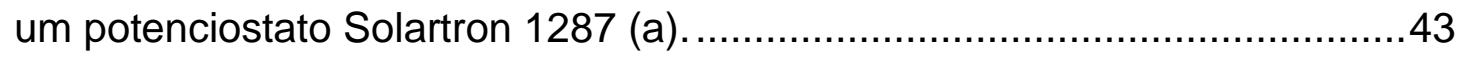

Figura 17 - Curvas de viabilidade celular pelo método de análise colorimétrica. ...46 Figura 18 - Resultados da força de retenção magnética para as ligas testadas neste estudo e para o grupo controle.

Figura 19 - Força retentiva magnética e \% Fe (em massa) associadas às ligas investigadas.

Figura 20 - Variação do potencial de circuito aberto ao longo do tempo de imersão em PBS naturalmente aerada à $25^{\circ} \mathrm{C}$ 48

Figura 21 - Curvas de polarização anódica potenciodinâmica após dois de imersão em solução PBS naturalmente aerada à $25^{\circ} \mathrm{C}$ 49

Figura 22 - Micrografias obtidas por MEV das amostras polarizadas anodicamente pela técnica potenciodinâmica, após 2 dias de imersão em solução PBS à 25ํㅜ A) aço 1802; B) aço 316L

Figura 23 - Micrografias obtidas por MEV das amostras do aço 17-4PH PIM, polarizadas anodicamente pela técnica potenciodinâmica, após 2 dias de imersão em solução PBS à 25ํㅜ; A) vista geral; B) região interna ao pite. ...51

Figura 24- EDS da amostra do aço 17-4PH PIM após polarização.

Figura 25 - Micrografias obtidas por MEV das amostras do aço PM2000, polarizadas anodicamente pela técnica potenciodinâmica, após 2 dias de imersão em solução PBS à $25^{\circ} \mathrm{C}$; A) Pequenos pites indicados por setas; B) Indicação de pites (setas pretas) e poros (setas brancas) na superfície da liga em maior aumento. .52

Figura 26 - Curvas de polarização anódica obtidas pelo método "stair-step" para 2 dias de imersão em solução PBS naturalmente aerada e a $25^{\circ} \mathrm{C}$ .53

Figura 27 - Micrografia obtida por MEV da amostra do aço PM2000 polarizada anodicamente pela técnica "stair-step", após 2 dias de imersão em solução PBS a $25^{\circ} \mathrm{C}$; A) aumento de 500X; B) aumento de 1000X. 
Figura 28 - Micrografias obtidas por MEV da amostra do aço 17-4PH PIM polarizada anodicamente pela técnica stair-step, para 2 dias de imersão em solução PBS a 25ㄷ; A) Aumento de 500X; B) Aumento de 1000X. .55

Figura 29 - Micrografias obtidas por MEV de amostras do aço 1802 polarizada anodicamente pela técnica stair-step, após 2 dias de imersão em solução PBS à 25ㄷ; A) Elétrons secundários; B) Elétrons retroespalhados. .56

Figura 30 - Diagramas de impedância do aço 1802 em solução PBS naturalmente aerada e à 25ํㅡ: (a) Bode (Ângulo de fase); (b) Bode (Módulo de Z); (c) Nyquist.

Figura 31 - Diagramas de impedância do aço PM2000 em solução PBS naturalmente aerada à 25을 (a) Bode (Ângulo de fase); (b) Bode (Módulo de Z); (c) Nyquist.

Figura 32 - Diagramas de impedância do aço 316L em solução PBS naturalmente aerada e a 25ํㅡ: (a) Bode (Ângulo de fase); (b) Bode (Módulo de Z); (c) Nyquist.

Figura 33 - Diagramas de impedância do aço 17-4PH PIM em solução PBS Diagramas de impedância do aço 17-4PH PIM em solução PBS naturalmente aerada à 25ํㅡ: (a) Bode (Ângulo de fase); (b) Bode (Módulo de Z); (c) Nyquist.

Figura 34 - Diagramas de Bode (ângulo de fase) dos aços PM2000, 316L, 1802 e 17-4PH PIM em solução PBS naturalmente aerada à 25ำ $\mathrm{C}$ : (a) 2 dias de imersão; (b) 21 dias de imersão. .64

Figura 35 - Diagramas de Nyquist dos aços PM2000, 316L, 1802 e 17-4PH PIM em solução PBS naturalmente aerada à 25으 C: (a) 2 dias de imersão; (b) 21 dias de imersão. 66

Figura 36 - Circuitos elétricos equivalentes propostos para caracterizar a camada passiva das ligas investigadas neste estudo.

Figura 37 - Representação dos modelos físicos adotados para explicar o comportamento eletroquímico dos aços ensaiados. 68

Figura 38 - Valores da resistência da camada interna do filme passivo, das ligas ensaiadas, obtidos pelos ajustes dos resultados experimentais ao CEE da Figura 36 . .72

Figura 39 - Gráficos de Mott-Schottky para o aço 316L após diferentes períodos de imersão, em solução PBS naturalmente aerada à $25^{\circ} \mathrm{C}$ .73 
Figura 40 - Gráficos de Mott-Schottky para o aço 316L após 12 horas, 2, 7, 14 e 21 dias de imersão, em solução PBS naturalmente aerada à $25^{\circ} \mathrm{C}$ .74

Figura 41 - Determinação do potencial de banda plana. .75

Figura 42 - Valores da concentração de doadores de carga no filme passivo do aço 316L, determinados a partir dos gráficos de Mott-Schottky da Figura 39, na região de potenciais entre $-0,4 \mathrm{Ve}+0,25 \mathrm{~V}$. .76

Figura 43 - Valores da concentração de aceitadores de carga no filme passivo do aço 316L, determinados a partir dos gráficos de Mott-Schottky da Figura 39 na região de potenciais entre $-1 \mathrm{~V}$ e $-0,4 \mathrm{~V}$. .76

Figura 44 - Valores da concentração de dopantes no filme passivo do aço 316L, determinados a partir dos gráficos de Mott-Schottky (Figura 39).

Figura 45 - Gráficos de Mott-Schottky para o aço PM2000 após diferentes períodos de imersão, em solução PBS naturalmente aerada à $25^{\circ} \mathrm{C}$. ...........78

Figura 46- Gráficos de Mott-Schottky para o aço PM2000 após diferentes períodos de imersão, em solução PBS naturalmente aerada à $25^{\circ} \mathrm{C}$ .79

Figura 47 - Valores da concentração de doadores de carga no filme passivo do aço PM2000, determinados a partir dos gráficos de Mott-Schottky (Figura 45) na região de potenciais entre $-0,4 \mathrm{Ve}+0,25 \mathrm{~V}$. 79

Figura 48 - Valores da concentração de aceitadores de carga no filme passivo do aço PM2000, determinados a partir dos gráficos de Mott-Schottky (Figura 45) na região de potenciais entre $-1 \mathrm{~V}$ e $-0,4 \mathrm{~V}$

Figura 49 - Valores da concentração de dopantes no filme passivo do aço PM2000, determinados a partir dos gráficos de Mott-Schottky (Figura 45). ..81

Figura 50 - Gráficos de Mott-Schottky para o aço PM2000 e 316L após diferentes períodos de imersão, em solução PBS naturalmente aerada à $25^{\circ} \mathrm{C}$ .82

Figura 51 - Valores da concentração de doadores de carga no filme passivo dos aços PM2000 e 316L, determinados a partir dos gráficos de Mott-Schottky (Figura 50) na região de potenciais entre $-0,4 \mathrm{~V} \mathrm{e}+0,25 \mathrm{~V}$. .82

Figura 52 - Valores da concentração de aceitadores de carga no filme passivo dos aços PM2000 e 316L, determinados a partir dos gráficos de Mott-Schottky (Figura 50) na região de potenciais entre $-1 \mathrm{~V}$ e $-0,4 \mathrm{~V}$.

Figura 53 - Análise quantitativa por XPS de Fe (III) e Cr (total) na superfície da liga PM2000 após 2, 7, 14 e 21 dias de imersão em PBS. 
Figura 54 - Análise quantitativa por XPS para o Y e AI (total) na superfície da liga PM2000 após 2, 7, 14 e 21 dias de imersão em PBS..................................85 Figura 55 - Análise quantitativa por XPS para o $\mathrm{O}^{2-}, \mathrm{OH}^{-}$, e $\mathrm{H}_{2} \mathrm{O}$ na superfície da liga PM2000 após 2, 7, 14 e 21 dias de imersão em PBS. ............................86 


\section{LISTA DE ABREVIATURAS}

$\mathrm{BH}(\max ) \quad$ Produto máximo de energia magnética produzido por um imã

CEE

$\mathrm{C}_{\text {int }}$ Circuito elétrico equivalente

$\mathrm{CPE}_{\mathrm{ext}}$

Capacitância da camada interna do filme passivo

$\mathrm{CPE}_{\text {int }}$

Capacitância do elemento CPE referente a camada externa do filme passivo

$\mathrm{CPE}_{\text {int }} \quad$ Capacitância do elemento CPE referente a camada interna do filme passivo

E corr Potencial de Corrosão

$E_{p}$

Potencial de pite

ECS

Eletrodo de Colomelano Saturado

EIE

Espectroscopia por Impedância Eletroquímica

$\mathrm{i}_{\text {corr }}$

Densidade de Corrente de Corrosão;

IRM Imagem por Ressonância Magnética

MEM

Meio Mínimo Essencial de Eagle

MEV

Microscopia Eletrônica de Varredura

MGOe

Mega Gauss Oerst : unidade de medida do produto máximo de energia de um imã;

$\mathrm{N}_{\mathrm{A}} \quad$ Densidade de aceitadores de cargas de Mott-Schottky

$N_{D} \quad$ Densidade de doadores de cargas de Mott-Schottky

$\mathrm{N}_{\mathrm{a}} \quad$ Densidade o de dopantes ou portadores de cargas da técnica de Mott-Schottky

NdFeB Liga magnética de Neodímio-Ferro-Boro

PBS

Solução Salina Tamponada por Fosfato

PIM Moldagem de pós por injeção

$R_{\text {ext }}$

Resistência da camada externa do filme passivo

$\mathrm{R}_{\text {int }}$

Resistência da camada interna do filme passivo

SmCo

Liga magnética de Samário-Cobalto

$\mathrm{T}$

Tesla: unidade de medida de densidade de fluxo magnético

$\mathrm{U}_{\mathrm{ib}}$

Potencial de banda plana

XPS

Espectroscopia Fotoelétrica por Raio-X 


\section{INTRODUÇÃO}

Os objetivos tradicionais da odontologia reparadora têm sido refinados em função da crescente demanda por trabalhos mais estéticos e duradouros. Esta odontologia reparadora busca o restabelecimento da função mastigatória, total ou parcialmente comprometida, devido à perda de elementos dentais. Dentre as inúmeras técnicas reparadoras, podem-se citar as restaurações diretas e indiretas, próteses totais, parciais, removíveis e, mais recentemente, as próteses sobre implantes. Como princípio básico de todas as técnicas reparadoras, tem-se a substituição parcial ou total do dente perdido por um material restaurador ou protético. Este deve ficar retido no dente ou boca e manter-se estável durante a mastigação. Para permitir esta retenção, as resinas compostas utilizam-se dos sistemas adesivos, enquanto nas restaurações de amálgama, o material é condensado em preparos cavitários retentivos, para que este fique retido mecanicamente (GARONE et al., 2003). As próteses totais aderem à fibromucosa pelo mesmo princípio que uma película de água entre duas placas de vidro dificulta a separação das mesmas (TURANO e TURANO, 1988). As próteses fixas utilizam os dentes remanescentes como pilares, e as próteses removíveis, como apoios (ZANETTI e LAGANÁ, 1996). Já as próteses sobre implante são confeccionadas sobre os mesmos para sua retenção ou suporte (DINATO E POLIDO, 2001).

Seja qual for o método de retenção empregado, o objetivo principal é sempre o conforto do paciente, causando a menor agressão possível aos dentes remanescentes. Visando este conforto e também a preservação dos elementos dentais, imãs vêm sendo empregados há muitos anos como método de retenção de próteses. WINKLER, em 1967, usou imãs com o objetivo de melhorar a função de próteses totais bimaxilares, posicionando os pólos magnéticos iguais na parte superior e inferior das próteses. Como os pólos magnéticos iguais se repelem, quando o paciente fechava a boca, a repulsão entre as próteses as comprimia contra a fibromucosa gengival, melhorando a fixação. FEDERICK (1976) e JACKSON (1987) utilizaram-se do princípio da atração magnética, ao invés da repulsão, e obtiveram melhor fixação das próteses. O princípio da atração magnética é baseado na interação mútua entre dois imãs, ou um imã e um material ferromagnético. $O$ conjunto formado pelo imã e um conector protético 
feito de material ferromagnético é denominado na Odontologia como um sistema de conexão magnética.

Um sistema de conexão magnética pode ser definido como uma unidade de retenção magnética composta por duas partes que se atraem mutuamente, devido ao campo magnético. Como mostrado na Figura 1, o sistema magnético é composto por um imã (A), fixado à prótese, e um conector protético (B), aparafusado ao implante (C).

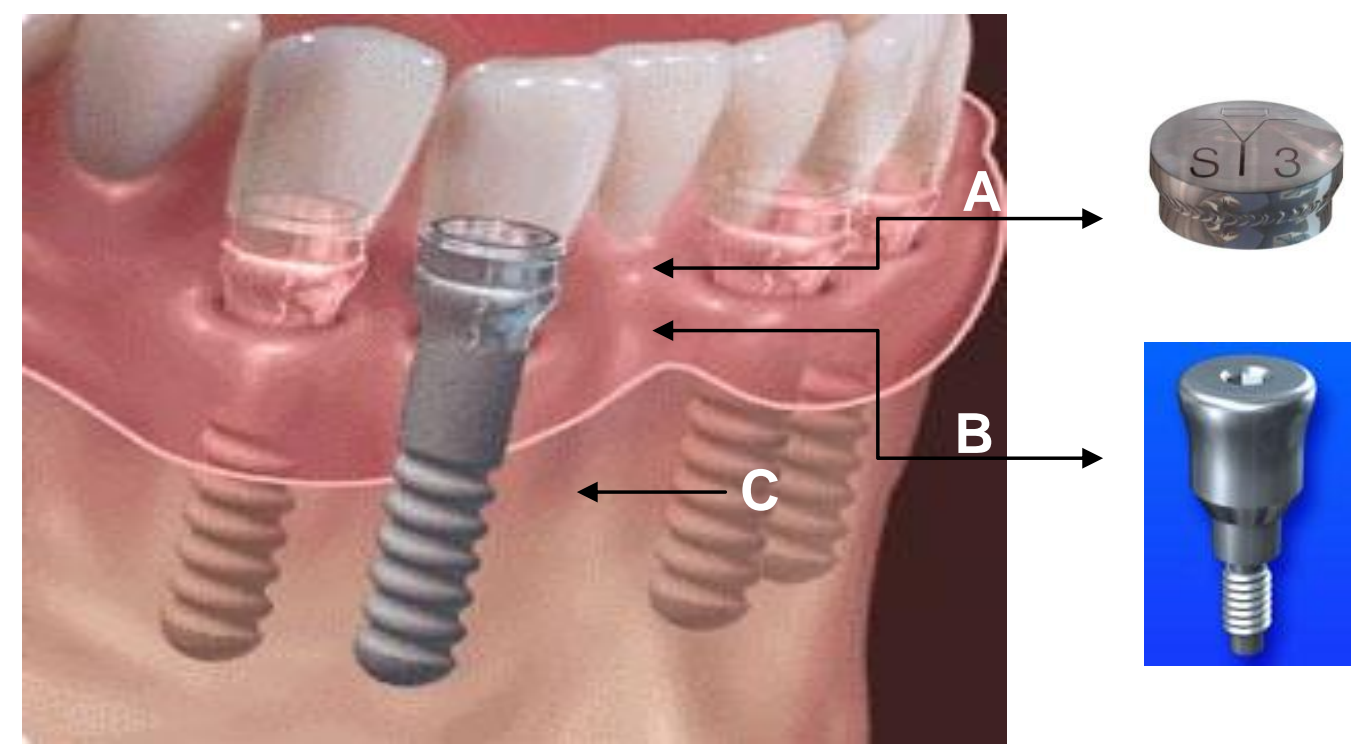

Figura 1 - Sistema magnético sobre implante. A) Imã; B) Conector protético; C) Implante. Fonte: Dyna Magnet Manual

A principal liga magnética utilizada para aplicações odontológicas (HARRIS, 1990) é baseada nos ímãs de terras raras com neodímio, ferro e boro (NdFeB) como principais elementos de liga. Estas foram desenvolvidas na década de 1980-90 (Mancini et al., 1999) e estão entre os mais efetivos materiais magnéticos comercialmente disponíveis, por possuírem um produto máximo de energia entre 36 MGOe e 50 MGOe (SALIBA-SILVA et al., 2004). Devido aos imãs de NdFeB apresentarem baixa resistência à corrosão em meios aquosos, sua aplicação na odontologia é precedida por processo que visa protegê-los do meio bucal, pois, como relatado por COSTA et al. (2001), a corrosão afeta diretamente a magnetização, diminuindo-a significativamente.

Além dos conectores magnéticos, também são utilizados na Odontologia conectores por retenção mecânica, baseados no princípio de fixação por atrito ou pressão entre os componentes. Comparando com os sistemas de 
próteses por retenção mecânica, a retenção magnética apresenta vantagens e desvantagens. Como vantagens podem ser citadas:

- A superfície plana entre o imã e o conector protético permite rotação durante a função, o que reduz a transmissão de forças laterais prejudiciais ao implante, ao dente e ao osso ao redor (Figura 2), resultando em um melhor prognóstico protético (SAYGILI e SAHMALI, 1998).

- Ímãs tendem a ser mais facilmente posicionados na prótese do que outros conectores, já que o alinhamento longitudinal não é crítico (WALMSLEY, 2002).

Como principais desvantagens podem ser citados o custo relativamente alto para os padrões nacionais e a baixa resistência à corrosão dos imãs de NdFeB (KITSUGl et al., 1992).
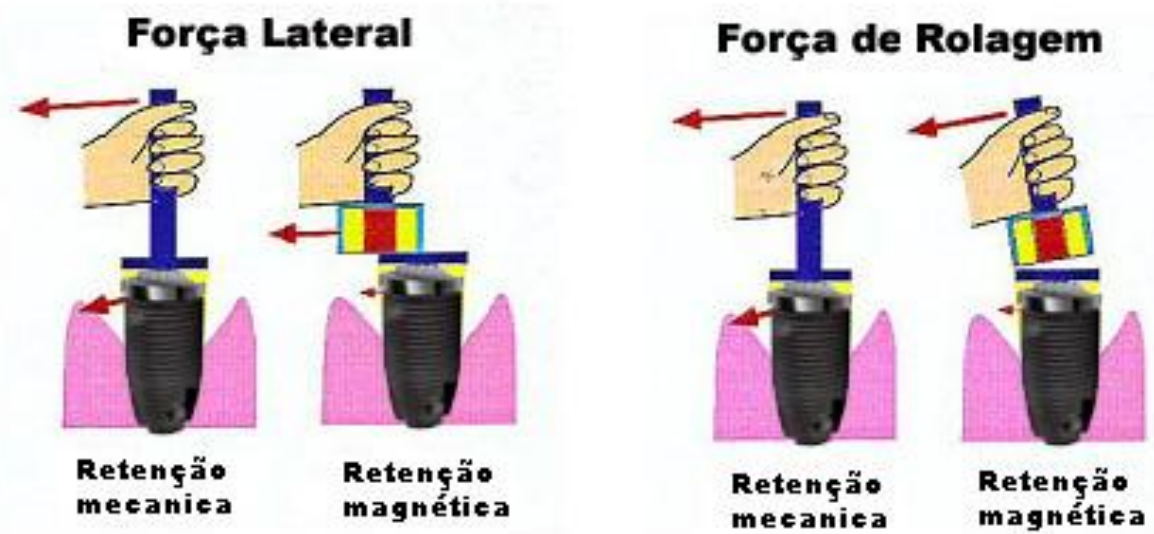

Figura 2 - Incidência das forças laterais sobre um sistema rígido e sobre um sistema magnético.

Os sistemas magnéticos também podem ser empregados sobre raízes remanescentes. O princípio para retenção é o mesmo, apenas tendo como diferença o conector protético, que é colado dentro da raiz ao invés de ser aparafusado ao implante.

Como exemplos de aplicação dos sistemas magnéticos têm-se as próteses parciais removíveis (Figura 3), totais (Figura 4), sobre implantes (Figura 5), auriculares (Figura 6 ) e faciais. 


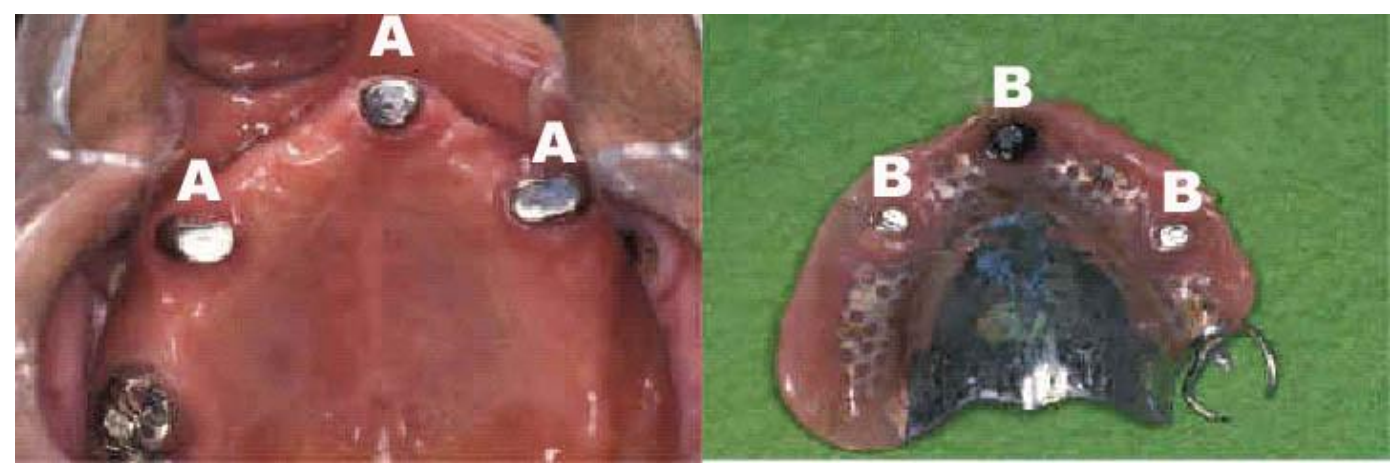

Figura 3 - Prótese parcial removível utilizando sistema imã-dente. A) Conectores protéticos (núcleos) sobre raízes. B) Imãs fixados na prótese. Fonte: MIYAO et al. 2005

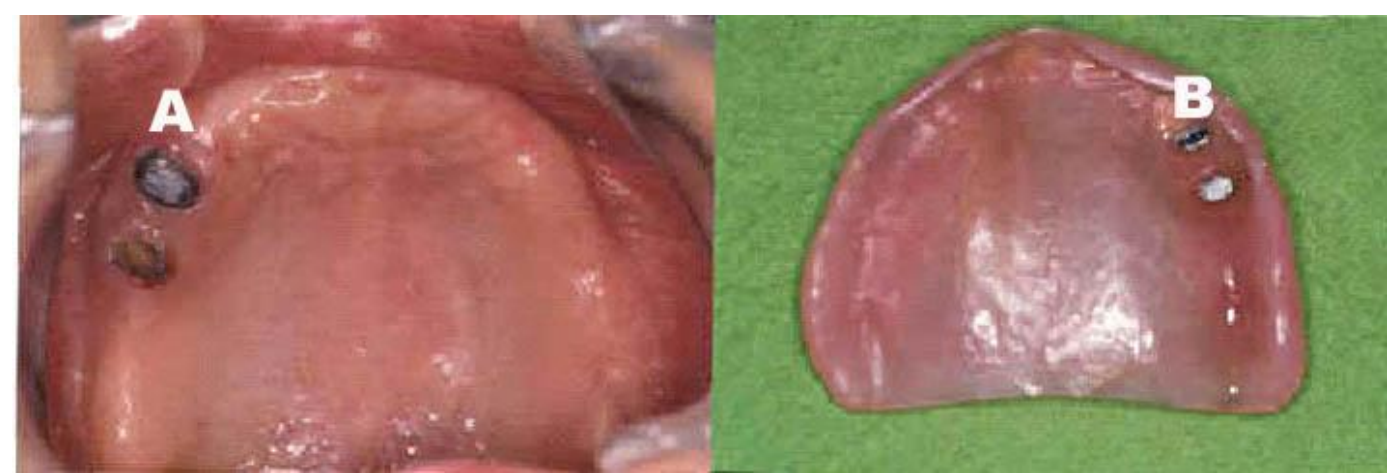

Figura 4 - Prótese total utilizando sistema imã-dente. A) Conectores protéticos (núcleos) sobre raízes. B) Imãs fixados na prótese. Fonte: MIYAO et al. 2005

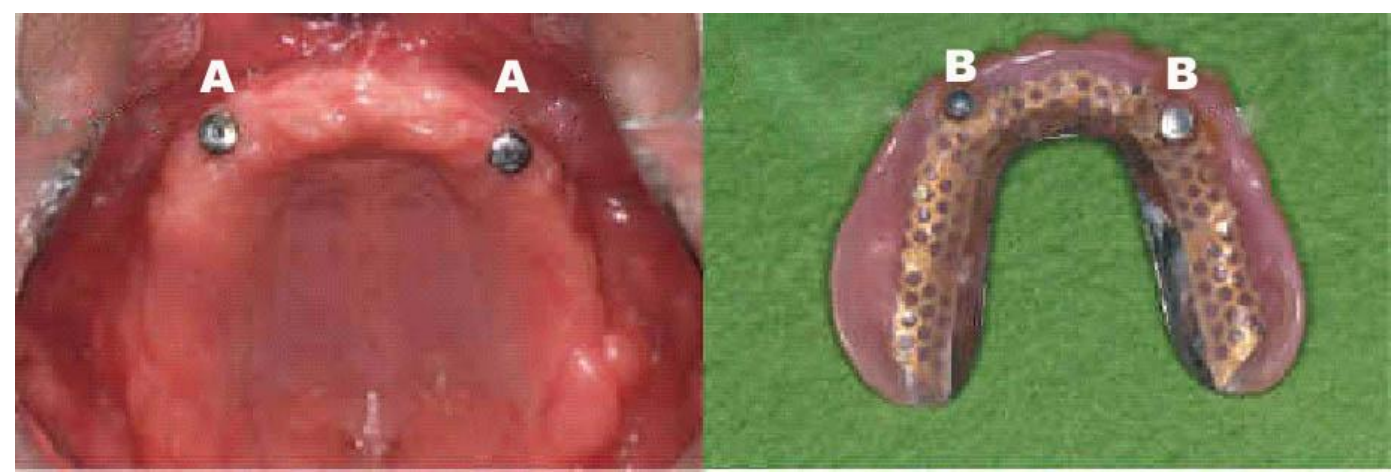

Figura 5 - Prótese total (overdenture) utilizando sistema imã-implante. A) Conectores protéticos sobre implante. B) Imãs fixados na prótese. Fonte: MIYAO et al. 2005 


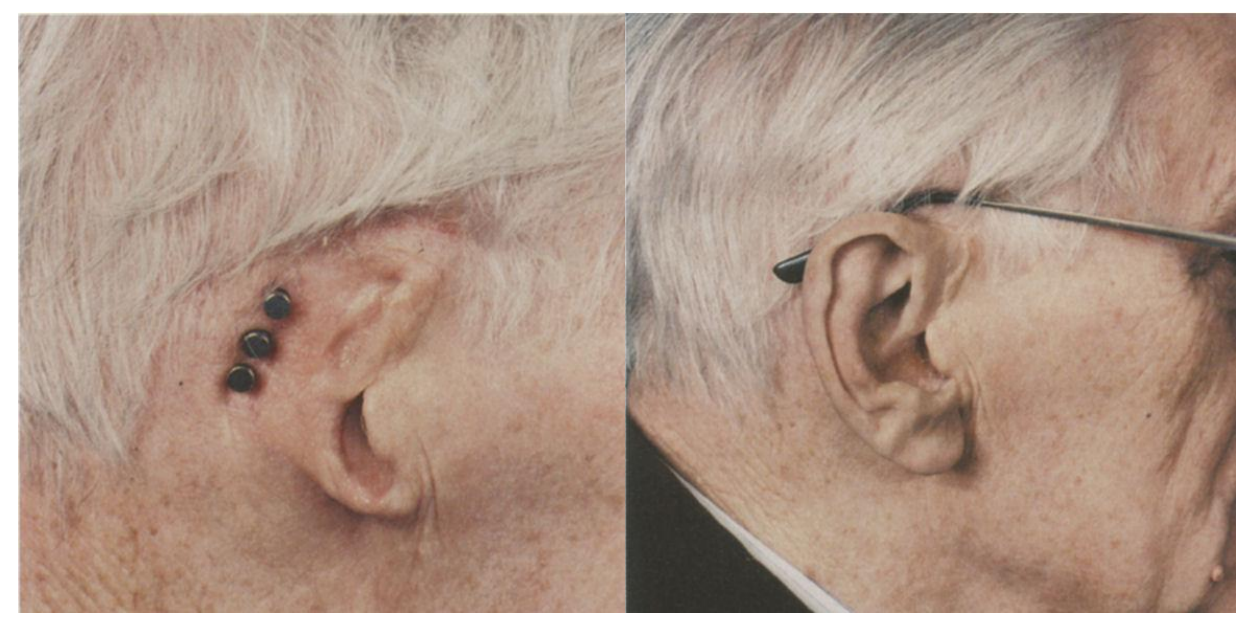

Figura 6 - Prótese auricular sobre implantes com retenção magnética. Fonte: THOMAS, 1995

$\mathrm{Na}$ busca por um maior acesso dos pacientes aos sistemas magnéticos, uma redução nos custos de fabricação dos componentes se faz necessária. Os conectores protéticos ferromagnéticos fabricados, em sua maioria, com ligas nobres de paládio-cobalto-gálio-platina (liga EFM ${ }^{1}$ ) ou em aço inoxidável ferrítico com elevada resistência à corrosão em meio bucal $\left(\mathrm{AUM}^{2} \mathrm{O}^{2}\right)$, representam cerca de $60 \%$ do custo dos componentes instalados sobre implantes. Os altos custos das ligas nobres são justificados pelo preço dos metais nobres empregados, enquanto o do aço AUM20 (normatizado pela SUS444), pelos direitos da patente.

Levantamento bibliográfico realizado (FLORES et al. 2004, COSTA et al. 2004, OH et al. 2005) indicou que outras ligas metálicas de menor custo, com propriedades ferromagnéticas e produzidas em escala industrial, poderiam ser aplicadas na fabricação de conectores protéticos para conexões magnéticas. Porém, são necessários estudos quanto a sua biocompatibilidade, resistência à corrosão e força atrativa magnética. Um dos aços estudados foi o PM2000, que segundo artigo de FLORES et al. (2004) apresentou biocompatibilidade in vitro e propriedades magnéticas. O aço inoxidável ferrítico Sandvik 1802 é outro material comercial que, segundo dados fornecidos pelo fabricante, apresenta resistência à corrosão equivalente ao aço 316L (aço cirúrgico) e propriedades magnéticas. $\mathrm{O}$ aço inoxidável 17-4 PH PIM é utilizado na confecção de bráquetes ortodônticos e devido à presença de fase martensítica apresenta propriedades magnéticas.

\footnotetext{
${ }^{1}$ Dyna Dental Engineering, Holanda

${ }^{2}$ Archi Steel Corporation, Archi,Japão
} 


\section{OBJETIVOS}

Os objetivos do presente trabalho foram 0 de estudar os comportamentos dos aços inoxidáveis comerciais PM2000, 1802 (DIN W. Nr. 1.4523) e 17-4PH PIM frente à citotoxicidade in vitro, retenção magnética e resistência à corrosão por meios de ensaios eletroquímicos, visando potenciais aplicações em sistema de fixação magnética para próteses odontológicas sobre implante.

\subsection{Justificativa do estudo}

Desde a década de 60, diversos autores vêm destacando a utilização dos sistemas de próteses retidas por imãs e suas vantagens e desvantagens com relação aos sistemas tradicionais. Com utilização em diversas áreas da odontologia, seu emprego só não é maior devido ao alto custo dos componentes protéticos magnéticos, os quais são cerca de quatro vezes mais caros que os componentes tradicionais.

O conector protético ferromagnético constitui cerca de $60 \%$ do preço dos componentes de uma conexão magnética. Materiais alternativos que venham a apresentar boa resistência à corrosão em meio bucal, biocompatibilidade e propriedades ferromagnéticas, seriam de grande interesse para futuras aplicações, visando reduzir o custo de produção deste componente protético. 


\section{REVISÃO DA LITERATURA}

\subsection{Aplicações clínicas do sistema de fixação magnética para próteses odontológicas}

FEDERICK, em 1976, descreveu a confecção de uma prótese com conexão magnética para um paciente operado de um carcinoma infiltrado em maxila, que havia perdido parte do palato e da órbita direita. A prótese foi confeccionada em duas partes, sendo uma colocada pela boca e a outra pela órbita. A união entre elas ocorria devido à atração entre os imãs posicionados em cada segmento da prótese.

GILLINGS, em 1983, descreveu os procedimentos clínicos e laboratoriais para o uso de imãs permanentes de samário-cobalto para retenção de próteses odontológicas. Os resultados obtidos, durante quatro anos, mostraram que as próteses totais magnéticas podem ser uma alternativa econômica à extração dental.

HIGHTON et al. (1988) realizaram testes in vitro para avaliar as características de retenção de uma prótese magnética sobre implantes. Como vantagem sobre os sistemas convencionais observou-se que, mesmo após 44 mil ciclos de retirada e recolocação da prótese, os imãs não perdiam força retentiva, diferentemente dos sistemas baseados na retenção por atrito. Concluíram que os imãs apresentaram retenção suficiente sem, contudo, sobrecarregar os implantes ou o rebordo ósseo.

Além das próteses intra-bucais, os sistemas magnéticos também são utilizados em próteses faciais, retidos por imãs instalados sobre implantes crâniofaciais. THOMAS (1995) relatou a utilização de próteses auriculares com conexões magnéticas sobre implantes faciais. As principais vantagens observadas sobre o sistema convencional de conexão barra-clipe foram: fácil higienização, devido ao melhor acesso aos implantes; fácil colocação da prótese pelo paciente; redução do stress sobre os implantes e tecido ósseo devido à dissipação das forças laterais. Mais recentemente, CHUNG et al. (2003) descreveram a confecção de uma prótese auricular sobre implantes crâniofaciais, utilizando uma subestrutura fundida, na qual foram instalados conectores magnéticos. Concluíram que esta técnica simplifica os procedimentos clínicos e laboratoriais, além de reduzir o custo da prótese. 
FREDERICK et al. (2004) relataram um caso clínico de um paciente portador de Mal de Parkinson, utilizando uma prótese total mandibular com retenção magnética. Concluíram que, quando o controle muscular do paciente é desfavoravelmente afetado por uma doença neurológica, este tipo de prótese pode ser corretamente indicado pela facilidade de colocação e higienização.

\subsubsection{Pacientes portadores de marcapasso cardíaco}

Para avaliar os cuidados na utilização de próteses com imãs em portadores de marca-passo cardíaco, HILLER et al. (1995) selecionaram 12 pacientes. Pequenos imãs cilíndricos foram colocados em contato com a pele sobre a região do marca-passo implantado. Durante o experimento os pacientes foram monitorados através do eletrocardiograma. Observaram que nove pacientes não apresentaram alterações no funcionamento do marca-passo. Os outros três pacientes apresentaram pequenas alterações, porém dentro do limite de segurança. Concluíram que, em pacientes com marca-passo implantado, o uso de imãs para aplicações dentais é seguro.

\subsubsection{Imagem por Ressonância Magnética (IRM)}

A força requerida para separar duas unidades magnéticas é maior quando se usam dois imãs do que quando uma das unidades é um ímã e a outra um material ferromagnético (Lei de Coulomb). Entretanto, nos sistemas magnéticos não se utilizam dois imãs. Na possibilidade do paciente ser submetido a um exame de imagem por ressonância magnética, deve-se retirar a parte móvel da prótese que contém o imã. Isto evita a desmagnetização do componente pelo campo magnético produzido no equipamento de IRM, o qual chega a ser cerca de 30.000 vezes superior ao campo magnético da Terra (HENNEL E KLINOWSKI, 1993).

IIMURO (1994) estudou os artefatos (distorções) de imagem em exames por IRM, provocados por conectores ferromagnéticos fixados aos implantes dentários. Concluiu que o uso destes conectores provoca um artefato de imagem severo, porém localizado. Desde que a área a ser observada não esteja muito próxima ao conector, as distorções nas imagens não impossibilitam a utilização da IRM como ferramenta de diagnóstico.

DEVGE et al. (1997) estudaram casos clínicos de pacientes portadores de implantes dentais submetidos a exame de IRM. Os implantes 
produziram artefatos de imagem que não prejudicaram os resultados do exame. Entretanto, os conectores magnéticos, fixados aos implantes, provocaram uma grande distorção das imagens. Concluíram que os conectores magnéticos devem ser removidos para uma melhor visualização de áreas próximas aos implantes.

\subsection{Citotoxicidade in vitro}

Com o aumento nas exigências para o uso de cobaias em teste de toxicidade de possíveis biomateriais, tem sido evidenciada a importância dos ensaios in vitro. Os testes de citotoxicidade in vitro possibilitam distinguir entre materiais tóxicos e não tóxicos de forma relativamente rápida e de baixo custo. Os efeitos tóxicos incluem morte celular, alterações na permeabilidade da membrana celular, inibição enzimática, entre outros. De acordo com o Órgão Internacional de Padronização (International Standard Organization-ISO), norma ISO10993 parte 1, este deve ser o ensaio inicial para avaliar a biocompatibilidade de qualquer material candidato a ser utilizado como biomaterial. Após este estudo, e ficando comprovada a não citotoxicidade, o material poderá ser submetido a ensaios em animais de laboratório.

ROGERO et al (2003) padronizaram uma metodologia para ensaios de citotoxicidade in vitro baseada na ISO 10993-5 (1992). Por esta metodologia, extratos dos metais estudados são colocados em contato com uma cultura celular de mamíferos com linhagem pré-estabelecida. Após um período de incubação, é adicionado o corante supravital vermelho neutro, que será incorporado pelas células viáveis. O corante vermelho neutro é solúvel em água e atravessa a membrana celular, ficando armazenado, dentro da célula, nos lisossomos. A presença de possíveis substâncias tóxicas, nos extratos obtidos dos metais, pode provocar danos às membranas celulares, ocasionando uma redução da captura do corante. Isto permite distinguir entre as células vivas (viáveis) daquelas danificadas ou mortas. A fim de que não seja necessária a contagem individual das células, utiliza-se um espectrofotômetro para medir a densidade ótica e relacionar com a quantidade de corante incorporado pela população de células. Os valores obtidos são utilizados para calcular a média de viabilidade celular, comparando-se com o grupo de controle positivo e assim determinar o índice de citotoxicidade $\mathrm{IC}_{50 \%}$. Este índice representa a concentração do extrato que provoca dano ou morte celular em $50 \%$ da população de células no ensaio. Por 
metodologia comparativa, as curvas de viabilidade dos extratos estudados devem estar acima do $\mathrm{IC}_{50 \%}$ para serem considerados não citotóxicos.

GRANCHI et al. (1998) estudaram os efeitos dos íons metálicos, decorrentes da corrosão de implantes, em uma cultura celular mononucleada. Foram empregados extratos de cromo, níquel e cobalto, por serem os elementos químicos mais comuns em ligas metálicas utilizadas na fabricação de implantes ortopédicos. Além disso, seus produtos de corrosão estão, geralmente, associados às reações teciduais inflamatórias. Concluíram que os extratos de cromo, níquel e cobalto induzem citotoxicidade em células isoladas. Esta ocorrência depende da concentração e tipo do íon metálico, assim como do tempo de contato com as células mononucleadas.

KIM et al. (2005) demonstraram que o aumento nos teores de níquel e molibdênio no aço $316 \mathrm{~L}$ resultou em maior liberação de íons metálicos, o que ocasionou maiores índices de citotoxicidade em comparação com o aço $316 \mathrm{~L}$ convencional.

\subsection{Corrosão de aços inoxidáveis e técnicas eletroquímicas}

A corrosão é definida por Gentil (GENTIL, 1996) como a deterioração de um material, geralmente metálico, por ação química ou eletroquímica do meio ambiente, associada ou não a esforços mecânicos. Em situações particulares, os compostos metálicos resultantes deste processo formam uma camada protetora entre o meio corrosivo e o metal, diminuindo a taxa de corrosão. Esta pode ser uma camada passiva como, por exemplo, a formada sobre aços inoxidáveis em alguns meios.

O termo aço inoxidável é, comumente, empregado para designar ligas ferrosas que apresentam um teor mínimo de cromo de $11 \%$ em sua constituição (SEDRIKS, 1979). Sua principal característica é a formação de um filme passivo na superfície responsável pela resistência à corrosão destes aços. Outros metais como níquel, molibdênio, cobre, silício, titânio, alumínio entre outros podem também ser adicionados ao ferro para formar filmes mais protetores. A formação deste filme passivo é amplamente estudada por diversos autores (CHAO et al., 1981, BOJINOV, 1995), assim como sua estrutura química (OLSSON, 2003) e características de estabilidade e quebra (LIN et al., 1981, SCHULTZE e LOHRENGEL, 2000). 
O filme passivo sobre aços inoxidáveis é formado por óxidos de caráter dúplex, composto por uma camada externa rica em óxidos e hidróxidos de ferro e uma camada interna rica em óxido de cromo (CASTLE e CLAYTON, 1977, GINESAN e SMITH, 1988, HAKIKI et al, 1995, DA CUNHA BELO et al., 1998, HAKIKI e DA CUNHA BELO, 1998, BOJINOV et al., 1999, MARTINI e MULLER, 2000, MONTEMOR et al., 2000).

Segundo SATO (1990), a quebra do filme passivo pode ocorrer na presença de ânions, particularmente os halogenetos. Três diferentes mecanismos de quebra do filme passivo são propostos: mecânico, eletrônico e iônico. O processo mecânico ocorre devido à introdução de micro-fraturas ocasionadas pelas tensões internas durante o crescimento do filme. A quebra do filme passivo pelo mecanismo eletrônico é provocada pela corrente eletrônica produzida presumivelmente somente em filmes espessos. Durante o processo de oxidação anódica, os ânions do eletrólito penetram no óxido agindo como doadores de impurezas ocasionando um aumento nos níveis de energia dos elétrons do óxido. Em filmes espessos estes elétrons ganham energia suficiente para serem acelerados, provocando uma avalanche eletrônica que resulta na destruição localizada do óxido superficial. O processo iônico ocorre em função da competição, na interface óxido/eletrólito, por adsorção entre íons hidroxila e ânions agressivos como o cloreto $\left(\mathrm{Cl}^{-}\right)$. Os íons $\mathrm{Cl}^{-}$adsorvem no filme causando sua dissolução ou produzem lacunas de íons metálicos, que migram para formar uma vacância condensada na interface metal/óxido. Esta vacância pode induzir tensões mecânicas suficientes para a formação de microtrincas, as quais acabam ocasionando a quebra do filme passivo. Por fim, ocorre a exposição de uma pequena área do substrato metálico ao eletrólito, preferencialmente, em regiões de defeitos superficiais, tais como inclusões não metálicas.

SCHULTZE e LOHRENGEL (2000) publicaram uma revisão sobre a estabilidade, reatividade e quebra de filmes passivos. Um dos pontos levantados é a influência dos íons cloreto na corrosão por pite, que pode ser explicado por dois mecanismos. No primeiro a difusão de cloreto no óxido provoca instabilidade do mesmo, causando dissolução ativa. Pelo segundo mecanismo, a adsorção de íons cloreto provoca tensões internas no filme, ocasionado sua quebra. Em ambas as situações, após a quebra do filme passivo, os íons cloreto adsorvem no metal, acelerando a dissolução ativa. 
RONDELLI et al. (2004) estudaram o comportamento eletroquímico de um aço austenítico, isento de níquel, para aplicação ortopédica, por meio da técnica de espectroscopia de impedância eletroquímica (EIE). O experimento foi feito em 4 meios diferentes: solução salina tamponada por fosfato (PBS); meio mínimo essencial (MEM); MEM + 10\% soro bovino fetal (FCS); MEM + 10\% soro bovino fetal + linhagem de células fibroblásticas L929 (Cell). Os diagramas de ângulo de fase de Bode indicaram a presença de duas constantes de tempo. Os resultados foram ajustados por um circuito elétrico equivalente com duas combinações R-CPE em paralelo, compostas por um resistor $(R)$ e um elemento de fase constante $(C P E)$. $O$ primeiro $R_{1}+C P E_{1}$ foi relacionado à camada interna compacta do filme passivo, e o segundo $R_{2}+C_{2} E_{2}$ à camada externa. $A$ resistência do filme interno $\mathrm{R}_{1}$ esteve diretamente relacionada à resistência à corrosão do material, aumentando com o tempo de imersão, e dependente do meio diminuindo na seguinte seqüência $M E M>C$ Cell $>F C S>P B S$.

OKUNO et al, (2002) estudaram a resistência à corrosão dos aços SUS444 (AUM20) e SUS447J1, utilizados em sistemas de conexões magnéticas, através de curvas de polarização potenciodinâmica e monitoração do potencial de circuito aberto, em solução de $0,9 \%$ de $\mathrm{NaCl}$ à $37^{\circ} \mathrm{C}$. Como material de controle foi selecionado o aço cirúrgico 316L. Os resultados obtidos mostraram que os aços inoxidáveis SUS447J1 e SUS444 apresentam resistência à corrosão por pite mais elevada que o aço SUS316L, sendo que o aço SUS447J1 foi superior ao SUS444.

Segundo TAKADA et al. (2007), os conectores dentais ferromagnéticos são usualmente fabricados em aços ferríticos e austeníticos como o SUS444 (AUM20), SUSXM27, SUS447J1 e SUS316L (

Tabela 1). Neste estudo, o comportamento frente à corrosão foi examinado com foco nas propriedades eletroquímicas, em meios contendo 0,9\% $\mathrm{NaCl}$ e $1 \%$ de ácido lático, após 24 horas de imersão à $37^{\circ} \mathrm{C}$. As curvas de polarização anódicas e catódicas mostraram que os potenciais de corrosão de todos os aços mantiveram-se dentro da região passiva. O potencial de pite do aço SUS444 (+500 $\left.\mathrm{mV}_{\mathrm{Ecs}}\right)$ foi ligeiramente superior ao do SUS316L (+400 mV $\left.\mathrm{Ecs}\right)$, enquanto o SUSXM27 e SUS447J1 apresentaram potencial de pite ao redor de +1200 mV Ecs. Concluíram que os três aços inoxidáveis testados possuem 
resistência à corrosão superior ao SUS316L e, portanto, podem ser utilizados com segurança na fabricação de componentes para próteses magnéticas.

Tabela 1 - Composição química dos aços utilizados (\% em massa) por Takada et al .

\begin{tabular}{ccccc}
\hline SUS & Cr & Fe & Mo & Ni \\
\hline 444 & 19 & $>79$ & 2,0 & 0,18 \\
\hline 447J1 & 30 & $>67$ & 2,0 & 0,20 \\
\hline XM27 & 26 & $>72$ & 1,0 & 0,17 \\
\hline 316L & $16-18$ & $>65$ & 2,0 & 13,5 \\
\hline
\end{tabular}

KOIKE et al. (2007) estudaram o comportamento frente à corrosão dos aços SUS 444, SUSXM27, SUS447J1 e SUS316L. Dentre os ensaios do estudo, curvas de polarização anódicas potenciodinâmicas foram obtidas com taxa de varredura de $1 \mathrm{mV} / \mathrm{s}$. O meio escolhido foi uma solução desaerada de $0,9 \%$ de $\mathrm{NaCl}(\mathrm{pH} 7,4)$ à $37^{\circ} \mathrm{C}$. O potencial de quebra da camada passiva dos aços XM27 e 447J1 foi significativamente maior do que o do aço 316L. Concluíram que a resistência à corrosão dos aços ferromagnéticos XM27 e 447J1 é suficiente para permitir a aplicação destes materiais na cavidade bucal.

\subsubsection{Circuitos Elétricos Equivalentes (CEE)}

Os ajustes dos resultados experimentais de EIE a circuitos elétricos equivalentes são usados para caracterizar a camada passiva e permitem obter informações sobre suas características físicas. Os modelos de circuitos utilizam uma combinação de resistores, capacitores, elementos de fase constante (CPE) e de Warburg. O circuito proposto deve conter o menor número de componentes possíveis dentro de um erro aceitável. Seus elementos devem ter um significado físico claro quanto às propriedades do sistema que podem gerar esse tipo de resposta elétrica (BONORA et al., 1996)

Para o modelamento com circuitos elétricos equivalentes, muitas vezes são utilizados um elemento de fase constante (CPE), em substituição a um capacitor ideal, devido a não idealidade do sistema eletroquímico real. A impedância desse elemento $\left(Z_{C P E}\right)$ é dada pela seguinte relação:

$$
Z_{C P E}=\left(\frac{1}{Y_{0}}\right)(j \omega)^{-n} \quad \text { Equação } 1
$$


$\mathrm{Na}$ Equação 1, $\mathrm{Y}_{0}$ e $\mathrm{n}$ são constantes do CPE e representam, respectivamente, as características superficiais das espécies eletroativas independentes e a distribuição não uniforme de corrente, devido à rugosidade e imperfeições superficiais (MATINI e MULLER, 2000), $j=\sqrt{ }-1$ e $\omega$ é a freqüência angular ( $\omega=2 \pi f$, sendo $f$ a freqüência). Quando $n=1, Y_{0}=C$, o CPE é representado por um capacitor ideal (C). Se $n=0$, CPE é um resistor puro (LUI et al., 2003).

$\mathrm{Na}$ literatura vários modelos são propostos, para explicar as características físicas da camada superficial de aços inoxidáveis, e alguns destes estão representados na Figura 7.

A)
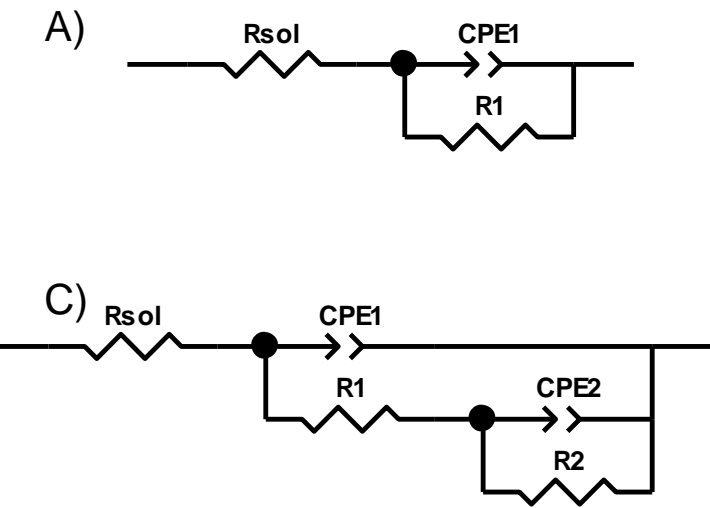
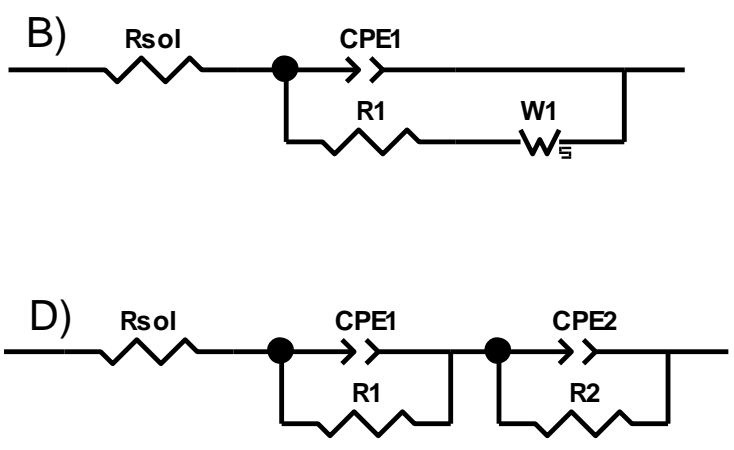

Figura 7 - Circuitos elétricos equivalentes propostos para caracterizar a camada passiva dos aços inoxidáveis (AZUMl et al., 1986, BUNDY et al., 1993, MONTEMOR et al, 2000, LIU et al., 2003, ANTUNES, 2006, TERADA, 2008).

O CEE (Figura 7A) é proposto para representar um filme passivo simples, no qual ocorre adsorção acompanhada por transferência de carga. É composto pela resistência da solução $\left(R_{\text {sol }}\right)$ em série com a resistência $\left(R_{1}\right)$ e a capacitância ( $\left.\mathrm{CPE}_{1}\right)$ do filme passivo, (GE et al., 2001 e WOLYNEC, 2003). A introdução de uma impedância de Warburg $\left(W_{1}\right)$, em série com a resistência de transferência de carga $\left(R_{1}\right)$, sugere a difusão de íons metálicos e lacunas de oxigênio no filme passivo (Figura 7B). $O$ circuito da Figura $7 \mathrm{C}$ propõe um elemento $R_{2}-C P E_{2}$ em série com a resistência do primeiro elemento $R_{1}-C P E_{1}$. Pode ser utilizado para explicar processos corrosivos em materiais com uma camada porosa ou defeituosa sobre uma outra camada, que pode ser compacta, 
como no caso de recobrimento com tintas ou alguns casos de filme passivo sobre ligas de titânio (ASSIS, 2006).

$\mathrm{Na}$ Figura 7D tem-se a resistência da solução $\left(R_{\text {sol }}\right)$ em série com dois elementos R-CPE para representar um sistema de camada dúplex. O elemento $\mathrm{R}_{1}-\mathrm{CPE}_{1}$ indica a impedância em altas freqüências e o componente $\mathrm{R}_{2}-\mathrm{CPE}_{2}$ representa a impedância em baixas freqüências. Segundo HAKIKI et al.(1995), DA CUNHA BELO et al. (1998), HAKIKI e DA CUNHA BELO (1998) e MONTEMOR et al.(2000), $\mathrm{R}_{1}$ e CPE $\mathrm{C}_{1}$ representam a resistência e a capacitância da camada externa do filme passivo, enquanto $R_{2}$ e $C P E_{2}$ correspondem à resistência e capacitância da camada interna do filme passivo.

\subsubsection{Propriedades eletrônicas do filme passivo - Técnica de Mott-Schottky}

A estrutura eletrônica dos filmes passivos dos aços inoxidáveis é descrita na literatura por um modelo de camada dúplex, formada por uma camada externa rica em óxidos e hidróxidos de ferro e uma camada interna rica em óxido de cromo. A camada externa apresenta comportamento de um semicondutor extrínseco tipo-n, e a interna, do tipo-p (HAKIKI et al, 1995, HAKIKI e DA CUNHA BELO, 1998, MARTINI e MULLER, 2000, MONTEMOR et al., 2000, ANTUNES 2006, TERADA 2008).

Esta característica do filme passivo, como semicondutor, pode ser expressa pelo gráfico do inverso da capacitância ao quadrado $\left(1 / \mathrm{C}^{2}\right)$ versus potencial (U), também conhecido como gráfico de Mott-Schottky (Figura 8). Este gráfico é obtido pelo método de Mott-Schottky, que consiste em medidas de impedância em uma freqüência estabelecida para a determinação dos valores de capacitância. A inclinação da reta obtida caracteriza o comportamento de um semicondutor tipo-n ou tipo-p (HAKIKI et al., 1995, GE et al., 2003, SHAHRYARI e OMANOVIC, 2007). No ponto de intersecção entre as retas tem-se o potencial de banda plana $\left(\mathrm{U}_{\mathrm{fb}}\right)$, correspondente ao potencial em que não há excesso de carga no interior do semicondutor. 


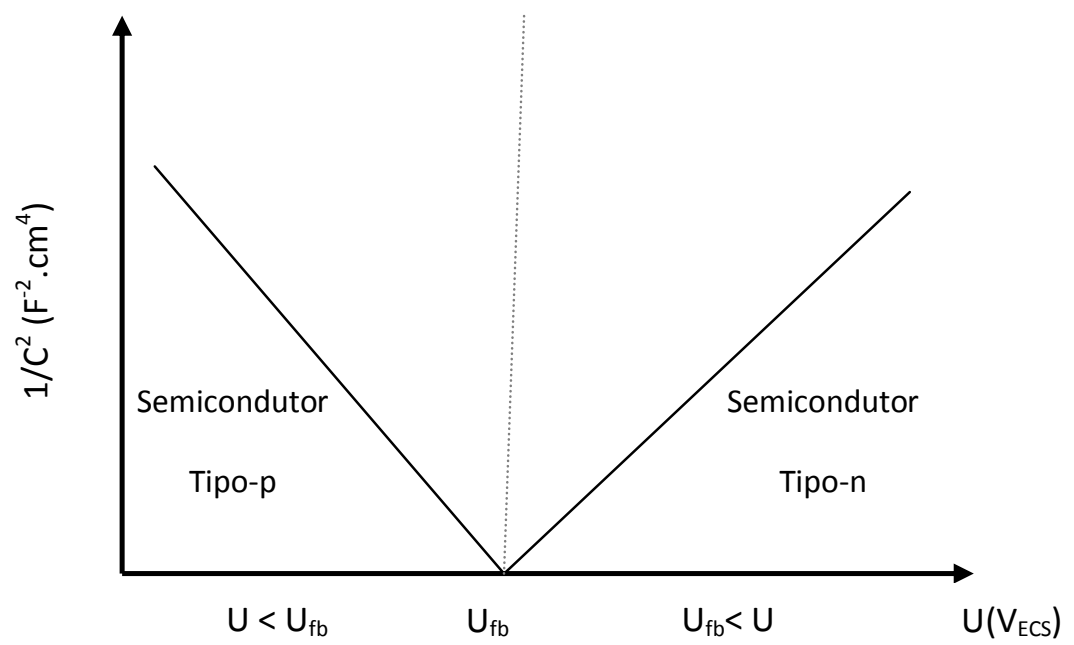

Figura 8 - Diagrama esquemático dos gráficos obtidos pelo método de MottSchottky.

Em potenciais diferentes do $U_{\mathrm{fb}}$ os semicondutores podem entrar em estado de acumulação ou depleção. Quando estão em acumulação, geram um contato ôhmico, o que permite a passagem de cargas elétricas praticamente sem resistência. Durante o estado de depleção, produzem um contato retificador, ou seja, a resistência à passagem de corrente elétrica depende da polaridade da tensão aplicada. A resposta de capacitância do diagrama de Mott-Schottky é dada pelo semicondutor quando em estado de depleção.

Em potenciais maiores que o $U_{\mathrm{fb}}$, os óxidos do filme passivo, que respondem como um semicondutor extrínseco tipo-p, estão em estado de acumulação. Por outro lado, os óxidos que respondem como semicondutor extrínseco tipo-n permanecem em depleção. Portanto, o gráfico de Mott-Schottky descreverá o comportamento de um semicondutor extrínseco tipo-n. Em potenciais inferiores ao $\bigcup_{\mathrm{fb}}$, a situação se inverte e tem-se a resposta de capacitância para um semicondutor extrínseco tipo-p.

Um semicondutor extrínseco tipo-p é caracterizado pelo excesso de cargas positivas, geradas por lacunas ou buracos eletrônicos e, portanto, são chamados de aceitadores de cargas. O semicondutor extrínseco tipo-n apresenta excesso de cargas negativas, causado por lacunas de íons metálicos, sendo denominado doador de carga. Tanto os aceitadores quanto os doadores de cargas são considerados dopantes (ANTUNES, 2006). A concentração de dopantes no filme passivo é inversamente proporcional à resistência à corrosão dos aços inoxidáveis (MONTEMOR et al., 2000, ANTUNES, 2006). 
O comportamento da interface do filme passivo com o eletrólito é descrito pela equação de Mott-Schottky (Equação 2), através da qual, pode ser calculado o número de dopantes.

$$
\frac{1}{c^{2}}=\frac{2}{s s_{0} \Theta N_{q}}\left(-U+U_{f b}+\frac{k T}{e}\right) \quad \text { Equação } 2
$$

Nesta equação, C representa a capacitância da interface do filme passivo com o eletrólito, $\varepsilon$ é a constante dielétrica do filme passivo, $\varepsilon_{0}$ o valor da permissividade do vácuo, e a carga elementar, $\mathrm{N}_{\mathrm{q}}$ a concentração de dopantes, $\mathrm{U}$ o potencial aplicado, $\mathrm{k}$ a constante de Boltzmann, $\mathrm{T}$ a temperatura em graus Kelvins e $\mathrm{U}_{\mathrm{fb}}$ o potencial de banda plana (MONTEMOR et al., 2000, GE et al., 2003, ANTUNES, 2006, SHAHRYARI e OMANOVIC, 2007).

SCHMUKI e BÖHNI correlacionaram as propriedades eletrônicas do filme passivo de aços inoxidáveis com a proteção à corrosão. Baseados na densidade de defeitos da banda semicondutora do filme de óxido observaram que os aços inoxidáveis com maior resistência à corrosão por pite, exibiram a menor densidade de dopantes no filme passivo. Concluíram que existe uma relação inversa entre a densidade de dopantes e a estabilidade do filme passivo.

HAKIKI et al. (1995) estudaram a estrutura eletrônica dos filmes passivos do aço inoxidável 304 e ligas de $\mathrm{Fe}-\mathrm{Cr}$, utilizando a técnica de MottSchottky em solução tamponada de borato. A composição do filme foi obtida por espectroscopia de elétrons Auger (AES). Correlacionando os resultados de MottSchottky e AES, concluíram que o filme passivo formado sobre o aço 304 e ligas de $\mathrm{Fe}-\mathrm{Cr}$ é composto por duas camadas, uma interna rica em cromo e outra externa rica em ferro. A camada externa de óxidos e hidróxidos de ferro apresenta resposta de um semicondutor extrínseco tipo-n, enquanto a camada interna de óxido de cromo, comportamento de um semicondutor tipo-p.

DA CUNHA BELO et al. (1998) investigaram as propriedades eletrônicas da camada de óxido formada no aço 316L, após 2000h de exposição a um ambiente típico de um reator refrigerado por água pressurizada. Os diagramas de Mott-Schottky foram correlacionados com a estrutura e composição do filme passivo, utilizando microscopia eletrônica de transmissão, espectroscopia Raman, difração de raios-X e microscopia de força atômica. Concluíram que os óxidos da camada mais interna do filme passivo (rica em cromo) apresentam 
comportamento de um semicondutor extrínseco tipo-p e a camada mais externa, formada por óxidos de níquel e ferro, apresenta resposta de um semicondutor tipo-n.

Em outro trabalho de DA CUNHA BELO et al. (1998), os pesquisadores estudaram as características semicondutoras de filmes formados sobre o aço inoxidável AISI 316L, após tratamento de passivação em ácido nítrico a 20\% durante 20 minutos. Como eletrólito foi utilizado água do mar artificial. Para as medidas de capacitância, em diferentes períodos, empregou-se a técnica de MottSchottky que permite investigar as propriedades eletrônicas dos filmes superficiais. A composição química superficial foi analisada através de espectroscopia fotoelétrica por raios-X (XPS) e de elétrons Auger (AES). No artigo, os autores salientam que a composição dos filmes passivos, formados sobre os aços inoxidáveis, depende do meio ao qual estão expostos. Em soluções neutras e não agressivas, o filme apresenta duas camadas: uma interna, rica em óxidos de cromo, e outra externa, essencialmente formada por óxidos de ferro. Após passivação em ácido nítrico, a camada interna permanece composta principalmente por óxidos de cromo, porém, na camada externa, tem-se uma mistura de óxidos de cromo e ferro com uma pequena concentração de níquel. Durante a imersão em água do mar artificial, o filme passivo formado sobre o aço 316 tornou-se mais rico em hidróxidos de cromo. Esta evolução na composição química do filme foi consistente com o aumento no potencial de corrosão, que também pôde ser explicado pela redução do número de dopantes obtidos por Mott-Schottky.

\subsection{Ligas metálicas selecionados para este estudo}

\subsubsection{Aço PM2000}

O aço PM2000® (Plansee GmbH - Áustria) é uma liga de FeCrAl produzida por mecanossíntese (mechanical alloying) e endurecida por dispersão de óxidos de ítrio. Esta liga combina excelente resistência à oxidação e corrosão em altas temperaturas devido à presença de uma camada fina e uniforme de partículas de ítrio. A mesma é fabricada por uma técnica complexa de metalurgia do pó, envolvendo a mistura mecânica dos elementos de liga para formar uma fina dispersão de óxido de ítrio, seguida por uma compactação em alta 
temperatura. Por fim, o material é extrudado à quente para a conformação de varetas ou barras. Segundo FLORES et al. (2004), a microestrutura do PM2000, no caso do material deformado não isostaticamente, apresenta grãos muito finos. Estes grãos têm cerca de $0,5 \mu \mathrm{m}$ e são alongados no sentido longitudinal da barra. Esta microestrutura também foi relatada por KLUEH et al. (2005). Após a recristalização da liga em alta temperatura, ocorre um crescimento considerável dos grãos para diâmetros entre 20 e 100 um (Figura 9 - FLORES et al. 2004).

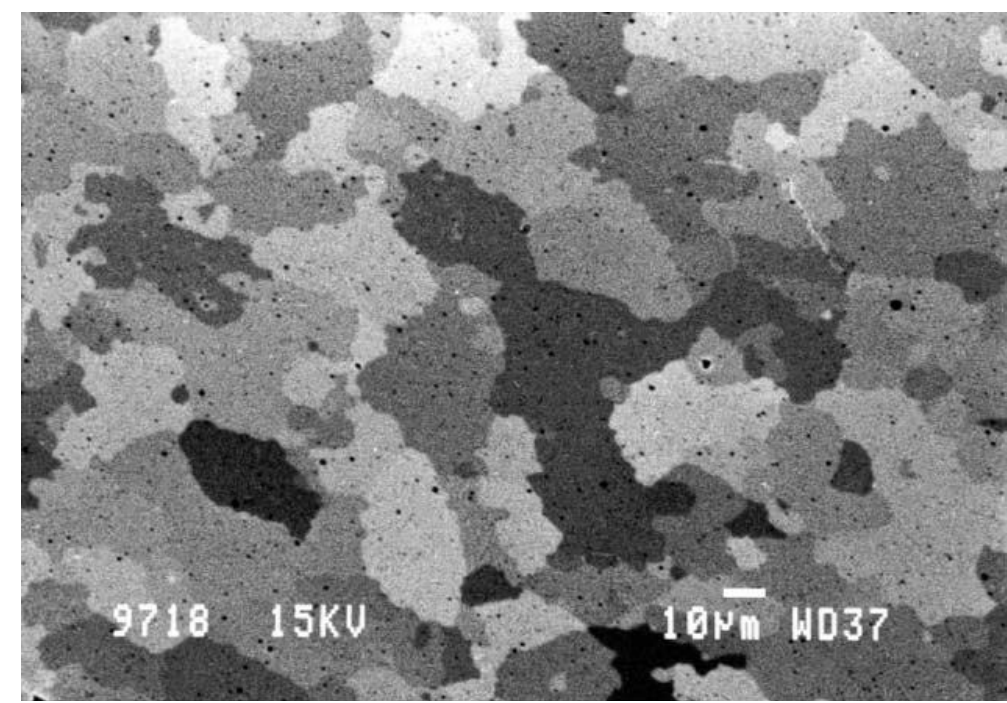

Figura 9 - Microestrutura do aço PM2000 após recristalização. Fonte: FLORES et al 2004

Outras características da liga PM2000 estudadas por FLORES et al. (2004) foram a biocompatibilidade in vitro de células osteoblásticas e o comportamento magnético por meio de curvas de histerese. Pelos resultados in vitro, observaram que os osteoblastos foram capazes de aderir e crescer sobre a superfície da liga PM2000, demonstrando, desta forma, a compatibilidade celular do material. As curvas de histerese revelaram que o PM2000 é um material magneticamente mole. Estes materiais são capazes de produzir um alto fluxo magnético gerado por uma corrente elétrica, ou uma grande indução magnética ocasionada por um campo externo. Por este motivo, os autores sugerem que novas pesquisas sejam feitas para estudar a possibilidade de utilizar a liga PM2000 em prótese com conectores magnéticos.

\subsubsection{Aço 17-4PH PIM}

A liga 17-4 $\mathrm{PH}$ é um aço inoxidável martensítico endurecível por precipitação $(\mathrm{PH})$. Devido a sua alta dureza e boa resistência à corrosão $(\mathrm{OH}$ et 
al., 2005, COSTA et al. 2006), o aço 17-4 PH possui um amplo campo de aplicações, especialmente em componentes médicos, automotivos, militares e aeronáuticos. Entretanto, sua alta dureza torna o material difícil de ser usinado. Conseqüentemente, muitos componentes feitos com este aço são fabricados pela técnica de moldagem de pós por injeção (PIM). A técnica PIM apresenta a vantagem de produção de peças de alta complexidade morfológica, alta densidade e com formato próximo ao do produto final. Uma das aplicações deste aço, produzido por PIM, é na fabricação de bráquetes ortodônticos (FLORES et al., 1994).

COSTA et al. (2004) compararam a resistência à corrosão e a citotoxicidade do aço 17-4PH obtido por metalurgia convencional e por moldagem de pós por injeção (PIM). Observaram que o aço 17-4PH, produzido por metalurgia convencional, apresenta uma microestrutura predominantemente martensítica com pequenos grãos (Figura 10B). Para o aço 17-4PH, fabricado pela técnica PIM, relataram uma microestrutura com grãos grandes e estrutura martensítica no interior dos mesmos, além de uma grande quantidade de poros arredondados (Figura 10A). Os autores supõem que estes grãos grandes, provavelmente, ocorrem devido às altas temperaturas nos estágios de présinterização e sinterização. As curvas cíclicas de polarização potenciodinâmica, em solução naturalmente aerada de cloreto de sódio (3\% em massa), indicaram que ambos os materiais são susceptíveis à corrosão por pite. Todavia, o aço 174PH PIM mostrou-se ligeiramente mais susceptível devido à presença de porosidades e inclusões de óxidos de silício no fundo destas. Ambos os aços não apresentaram efeitos citotóxicos

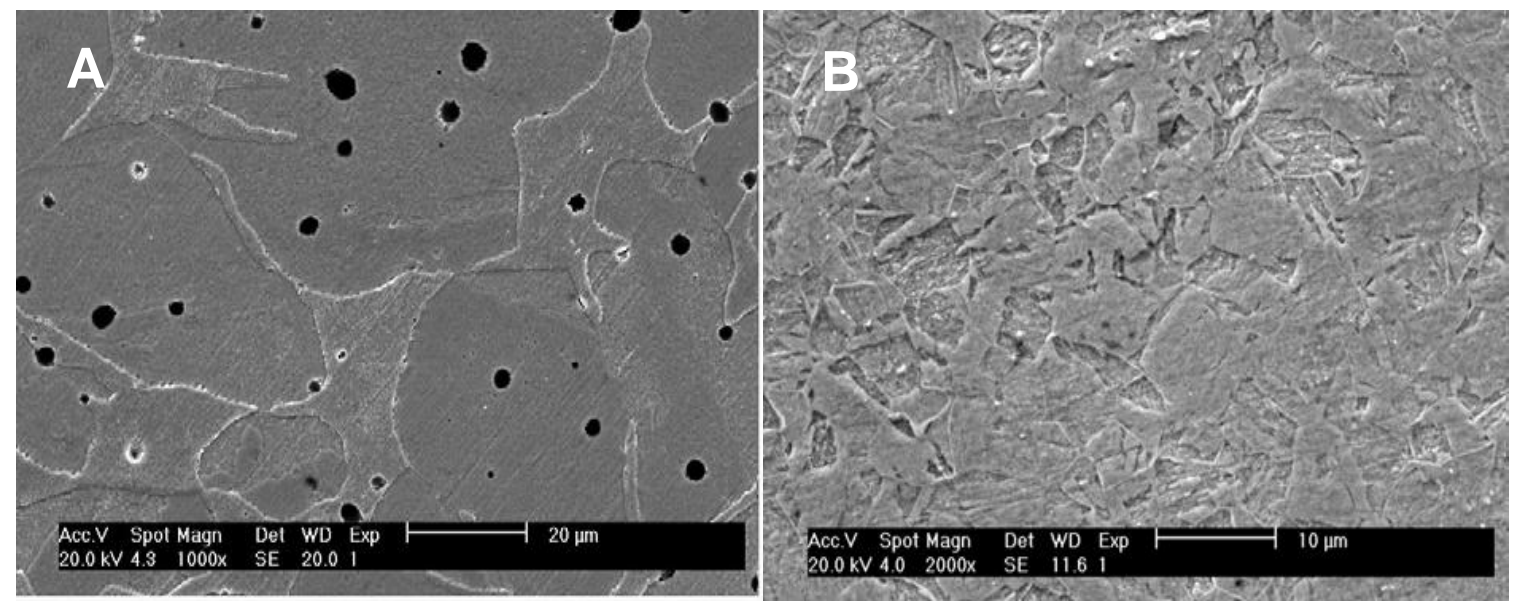

Figura 10 - Microestrutura do aço 17-4PH: A) produzido pela técnica de moldagem de pós por injeção (PIM); B) por metalurgia convencional. Ataque: Solução de Villela. Fonte: COSTA et al. (2004) 


\subsubsection{Aço Ferrítico Sandvik 1802}

A liga comercial 1802 (Sandvik-Brasil) é um aço inoxidável ferrítico isento de níquel, com $18 \%$ de $\mathrm{Cr}, 2 \%$ de $\mathrm{Mo}, 0,3 \%$ de $\mathrm{S}$ e $0,7 \%$ de $\mathrm{Ti}$, balanceado por Fe (em massa) e normatizado pela DIN W. Nr. 1.4523. Segundo BRUCE et al.(2002), a ausência de níquel evita a formação da fase austenítica. A presença de molibdênio na liga aumenta a resistência à corrosão por ser um forte formador de carbetos. O enxofre melhora a usinabilidade do material e o titânio é um refinador dos grãos, além de melhorar a resistência à oxidação e ser um excelente formador de carbetos e nitretos.

Até o momento, não foram encontradas publicações sobre o aço Sandvik 1802 na área científica. A disponibilidade de informações fica restrita ao catálogo fornecido pela Sandvik (General datasheet of precison wire 1802 Sandvik). Segundo a empresa, o aço Sandvik 1802 é um material magnético mole muito propício para o uso em válvulas solenóides e outros equipamentos eletromecânicos em meios altamente corrosivos. Na Tabela 2 observa-se um quadro comparativo da resistência à corrosão entre o aço Sandvik 1802 e o aço AISI 316L, em diferentes meios.

Tabela 2 - Resistência à corrosão do aço Sandvik 1802 comparado com o aço AISI 316L em diferentes meios.

\begin{tabular}{|l|c|}
\hline Ácidos fracos & Equivalente \\
\hline Ácidos fortes & Ligeiramente inferior \\
\hline Água contendo íons cloreto & Equivalente \\
\hline $\begin{array}{l}\text { Água contendo íons cloreto onde há } \\
\text { o risco de corrosão sob tensão }\end{array}$ & Superior \\
\hline
\end{tabular}

Devido à equivalência em resistência à corrosão com AISI 316L, em meios contendo cloreto, o aço 1802 pode ser utilizado na fabricação de máquinas de diálise que trabalham com soluções de $0,9 \%$ de $\mathrm{NaCl}$ e água contendo entre 10-200 ppm de íons $\mathrm{Cl}^{-}$. Segundo a Figura 11, obtida do catálogo fornecido pela Sandvik, o aço 1802 possui propriedades magnéticas equivalentes aos aços ferríticos, porém resistência à corrosão equivalente ao aço AISI 316L, o que lhe confere características promissoras para ser empregado na produção de conectores protéticos ferromagnéticos. 


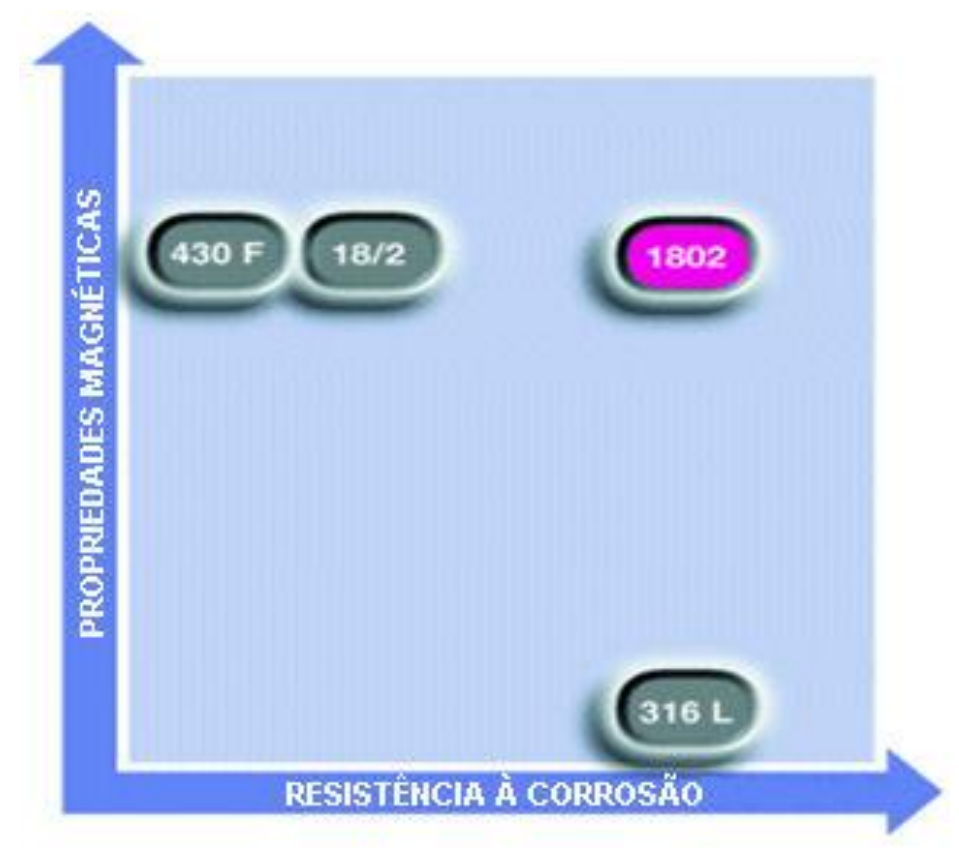

Figura 11 - Comparativo entre resistência à corrosão e propriedades magnéticas de diferentes aços. Fonte: General datasheet of precison wire 1802 - Sandvik

\subsubsection{Aço Austenítico AlSI 316L}

O aço $316 \mathrm{~L}$ é o biomaterial metálico mais utilizado na fabricação de próteses ortopédicas e dispositivos médicos (ANTUNES, 2006). Dentre as aplicações, incluem-se juntas artificiais, placas para fixação de fraturas ósseas, stents, entre outros, graças a uma combinação favorável de propriedades mecânicas, resistência à corrosão, biocompatibilidade satisfatória e custo relativamente baixo, quando comparado com outros biomateriais metálicos (SUMITA et al., 2000).

Em comparação ao aço AISI 302, o aço $316 \mathrm{~L}$ tem sua resistência à corrosão melhorada pela adição de 2-3 \% de molibdênio, aumento na porcentagem de níquel (que passou de $8-10 \%$ para $12-15 \%$ ) e redução na quantidade de carbono para níveis inferiores a $0,03 \%$. A presença de molibdênio, como elemento de liga no aço inoxidável, reduz a susceptibilidade à corrosão por pite e estabiliza pites metaestáveis (ILEVBARE e BURSTEIN, 2000).

Conforme a norma ASTM F-138, que estabelece as características de composição química e microestrutura dos aços inoxidáveis austeníticos para aplicações biomédicas, a microestrutura deve ser totalmente austenítica (Figura 12), isenta de ferrita delta. $\mathrm{Na}$ composição química tem-se a seguinte especificação para o aço inoxidável AISI 316L: $\leq 0,030 \% \mathrm{C}, \leq 1,0 \% \mathrm{Si}, \leq 2,0 \% \mathrm{Mn}$, $\leq 0,045 \% \mathrm{P}, \leq 0,030 \% \mathrm{~S}, 12,0-15,0 \% \mathrm{Ni}, 16,0-18,0 \% \mathrm{Cr}$, e $2,0-3,0 \%$ Mo. A 
presença da fase austenítica torna o aço não magnético e, apesar da ampla aplicação como biomaterial, esta propriedade não permite sua utilização para conectores protéticos magnéticos com aplicação odontológica.

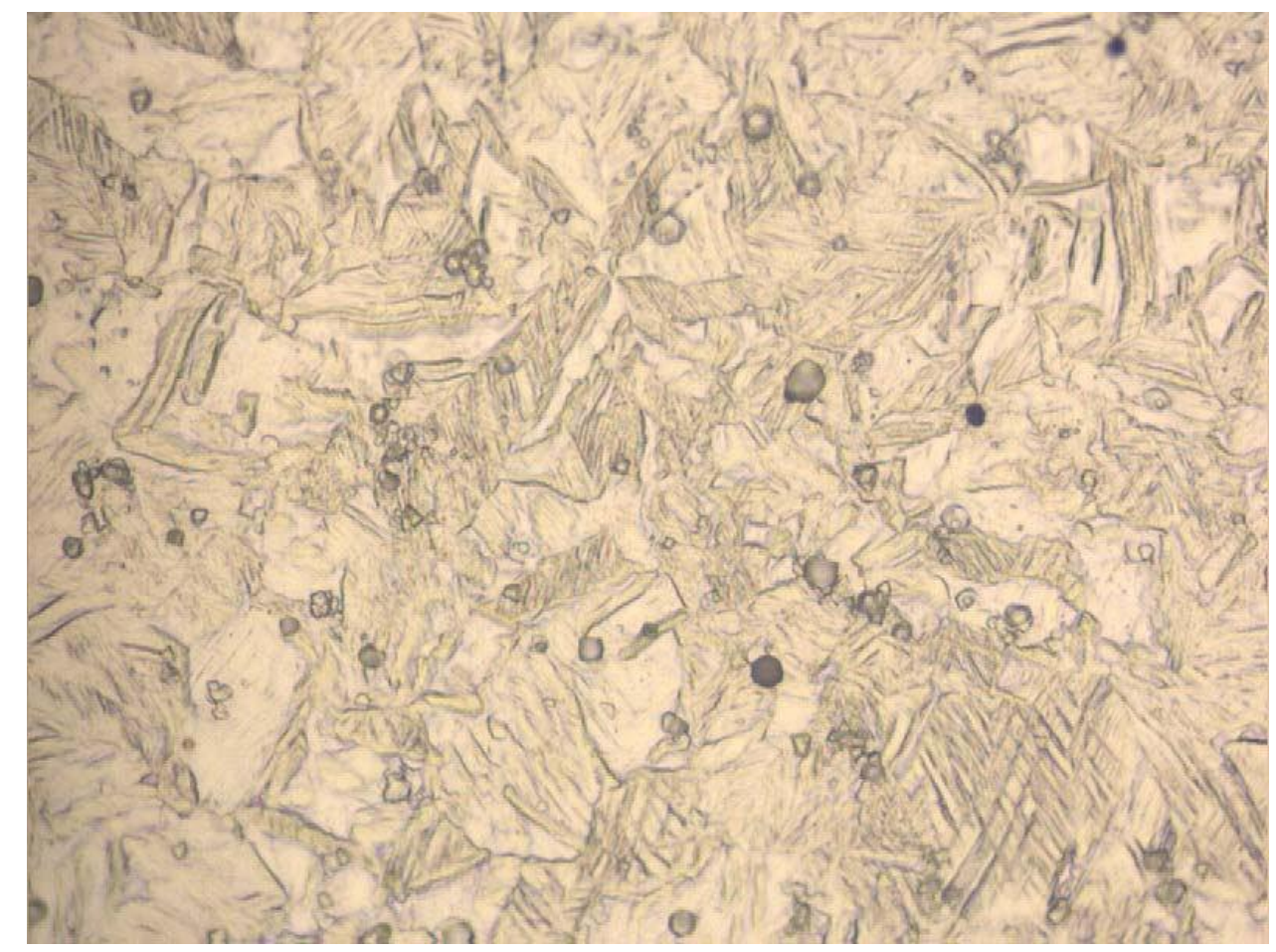

Figura 12 - Micrografia ótica da superfície do aço inoxidável 316L após ataque eletrolítico segundo procedimento $13 \mathrm{~b}$ da norma ASTM E407-99. Fonte ANTUNES, 2006.

ENDO et al. (2000), TAKADA et al. (2007) e KOIKE et al. (2008) utilizaram técnicas eletroquímicas para avaliar a resistência à corrosão de aços ferromagnéticos com aplicação em próteses odontológicas, sendo que o $316 \mathrm{~L}$ foi selecionado como material de referência.

\subsection{Espectroscopia Fotoelétrica por Raio-X (XPS)}

Uma das técnicas utilizadas para estudar e analisar a composição química da estrutura das camadas superficiais é a ESCA (Electron Spectroscopy for Chemical Analysis), também denominada XPS (X-ray Photoelectron Spectroscopy).

Descoberto no início do século 20 , o processo fotoelétrico foi desenvolvido para uso analítico na década de 60, principalmente, devido aos trabalhos pioneiros efetuados pelo grupo do pesquisador Kai Siegbahn (SIEGBAHN, 1974). Sua sensibilidade combinada com a capacidade de 
quantificar e determinar o estado químico dos elementos tornaram a técnica XPS uma das mais utilizada atualmente para análise de superfícies. (BRUNDLE et al., 1992).

Em amostras submetidas ao processo de corrosão, a XPS é utilizada na análise dos contaminantes de filmes finos, identificação do estado químico dos elementos e quantificação da composição elementar superficial.

A análise de superfície de um material é realizada medindo-se a energia dos fotoelétrons emitidos pela amostra, após ser atingida por um feixe de raios-X monoenergéticos. Os caminhos livres médios desses fotoelétrons, em materiais sólidos, são de 0,5 a $3 \mathrm{~nm}$, portanto, apenas a superfície do material é analisada. São normalmente utilizados os raios- $X$ emitidos pelo ânodo de $\mathrm{Mg}$ $(\mathrm{Ka}=1253,6 \mathrm{eV})$ ou de $\mathrm{Al}(\mathrm{Ka}=1486,6 \mathrm{eV})$. Os feixes de raios-X, com energia hu, excitam os elétrons superficiais da amostra que são ejetados com uma energia cinética $E_{c}$. A energia $E_{c}$ é calculada pela equação $E_{c}=h v-E_{L}$, sendo $E_{L}$ a energia de ligação do elétron emitido em relação ao vácuo. Como a energia dos raios-X é bem definida, os fotoelétrons ejetados da amostra têm uma distribuição de energia cinética constituída por picos discretos. As energias de ligação destes picos fotoelétricos permitem identificar os elementos presentes. Analisando-se a intensidade dos picos é possível obter a composição quantitativa superficial da amostra, enquanto que a posição exata de cada pico indica o estado químico do átomo emissor. 


\section{MATERIAIS E MÉTODOS}

\subsection{Materiais}

Para este estudo foram selecionadas amostras do aço inoxidável 17-4 PH (LUPATECH, Caxias do Sul, Brasil), confeccionado por moldagem de pós por injeção (PIM), do aço PM2000 (Plansee GmbH - Áustria) e do aço inoxidável ferrítico 1802 (Sandvik - Brasil). A resistência à corrosão destes aços foi avaliada utilizando-se técnicas eletroquímicas e os resultados foram comparados com os do aço inoxidável AISI 316L, escolhido como material de referência por ser a liga metálica mais empregada na fabricação de próteses ortopédicas. A Tabela 3 mostra a composição química dos materiais selecionados.

Tabela 3 - Composição química (\% em massa) dos aços utilizados neste estudo.

\begin{tabular}{lcccccccccc}
\hline & $\mathbf{C r}$ & $\mathbf{A l}$ & $\mathbf{Y}_{2} \mathrm{O}_{3}$ & $\mathbf{~ N i}$ & $\mathbf{M o}$ & $\mathbf{T i}$ & $\mathbf{M n}$ & $\mathbf{S}$ & $\mathbf{C u}$ & $\mathbf{F e}$ \\
\hline PM2000 & 22,0 & 5,6 & 0,5 & - & - & 0,51 & - & - & - & bal. \\
\hline 17-4PH PIM & 17,0 & - & - & 4 & - & - & - & 0,3 & 3,0 & bal. \\
\hline $\mathbf{1 8 0 2}$ & 18 & - & - & - & 2,3 & 0,7 & $\leq 0,05$ & 0,3 & - & bal. \\
\hline AISI 316L & 17,7 & - & - & 13,5 & 2,12 & - & 1,8 & - & - & bal. \\
\hline
\end{tabular}

\subsection{Teste de citotoxicidade in vitro}

O ensaio de citotoxicidade foi efetuado conforme a norma ISO 10.993 parte 5 (ISO 10.993, 1992). A avaliação in vitro da biocompatibilidade foi realizada pelo teste de citotoxicidade em cultivo de células de tecido conectivo de camundongos (NCTC Clone 929) da American Type Culture Collection, cultivadas em meio mínimo essencial de Eagle (MEM) à $37^{\circ} \mathrm{C}$, com adição de $10 \%$ de soro fetal bovino, 0,1 mM de aminoácidos não essenciais e $1 \mathrm{mM}$ de piruvato de sódio (Rogero et al., 2003).

Amostras com área de $5 \mathrm{~cm}^{2}$ dos aços inoxidáveis 17-4PH PIM, PM2000 e 1802 foram esterilizadas por autoclavagem a $120 \stackrel{\circ}{ } \mathrm{C}$ por 20 minutos. Em seguida, foram imersas em MEM, durante 10 dias a $37^{\circ} \mathrm{O}$, na proporção de 1 $\mathrm{mL} / \mathrm{cm}^{2}$, obtendo-se uma solução de ensaio com $100 \%$ de concentração. Foi feita a diluição seriada desta solução para obtenção das concentrações de $50 \%$, 25\%, $12,5 \%$ e $6,25 \%$ da inicial. Cada concentração foi distribuída em quatro poços de $50 \mu \mathrm{L}$ e cada poço recebeu 250.000 células $/ \mathrm{mL}$ da linhagem NCTC Clone 929, permanecendo incubado durante $24 \mathrm{~h}$ sob atmosfera úmida de $5 \%$ de $\mathrm{CO}_{2}$. Após este período, foi adicionada uma solução de corante vermelho neutro a $0,1 \%$. A 
quantificação do corante foi realizada após $3 \mathrm{~h}$ em espectrofotômetro leitor de ELISA (marca Tecan - modelo Sunrise) no comprimento de onda de 540nm. O corante, que se caracteriza como identificador da viabilidade celular, é incorporado pela população de células e essa incorporação é diretamente proporcional ao número de células viáveis no meio de cultura. $A$ análise colorimétrica permitiu investigar a viabilidade celular. Extratos das amostras, que induzem a toxicidade celular, foram avaliados em várias concentrações. A concentração que produziu redução de 50 \% na absorção do corante foi adotada como índice de citotoxicidade $\left(\mathrm{IC}_{50 \%}\right)$. O $\mathrm{IC}_{50 \%}$ representa a concentração do extrato que induz $50 \%$ de lise ou morte celular e, como conseqüência, a inibição da incorporação do vermelho neutro. Foram utilizadas como medida de comparação uma solução de fenol 0,02\% (controle positivo) e uma placa de titânio (controle negativo). O controle negativo é utilizado para demonstrar a resposta celular no ensaio e o controle positivo para comprovar uma resposta apropriada do sistema no teste.

\subsection{Força de retenção magnética}

No intuito de avaliar a força de retenção magnética entre um imã, utilizado em um sistema de conexão magnética, e os aços 17-4PH PIM,1802 e PM2000, foi desenvolvido um aparato para medição comparativa da força de retenção magnética (Figura 13).

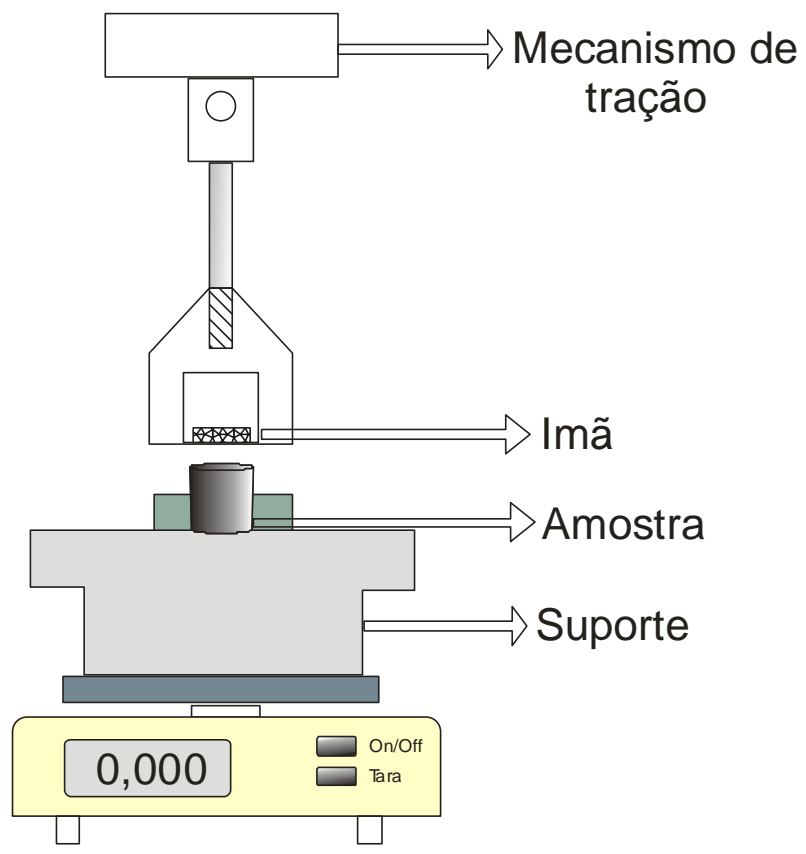

Figura 13 - Desenho esquemático do aparato para medição comparativa da força de retenção magnética. 
Utilizou-se uma balança digital (Quimis modelo BG 2000), sobre a qual, colocou-se um suporte para fixação das amostras, sendo em seguida zerada pelo recurso da tecla "tara". Posicionou-se, sobre a balança, um mecanismo para tração contendo um imã de $\mathrm{NdFeB}$, que foi ajustado até se obter contato com a amostra do aço. Desta forma, acionou-se o mecanismo de tração e monitorou-se o decréscimo de massa. Este decréscimo de massa representa o quanto a força de retenção magnética foi capaz de reduzir o peso da amostra+suporte, antes de ocorrer a separação dos componentes. Obtiveram-se 5 leituras do menor valor para cada amostra. Os valores obtidos foram normalizados pela área de contato entre o imã e as amostras $\left(0,138 \mathrm{~cm}^{2}\right)$ e expressos em $\mathrm{g} / \mathrm{cm}^{2}$. Esta metodologia foi aplicada às amostras dos aços 1802, 17-4PH PIM e PM2000. Como controle foi utilizado um conector ferromagnético comercial (Dyna Dental).

\subsection{Ensaios eletroquímicos}

Todos os ensaios eletroquímicos foram feitos em solução salina tamponada em $\mathrm{pH} 7 \mathrm{com}$ fosfato (PBS), naturalmente aerada e a $25^{\circ} \mathrm{C}$. A composição química da solução PBS é mostrada na Tabela 4.

Tabela 4 - Composição química da solução salina tamponada com fosfato (\% em massa).

\begin{tabular}{ccc}
\hline $\mathrm{NaCl}$ & $\mathrm{Na}_{2} \mathrm{HPO}_{4}$ & $\mathrm{KH}_{2} \mathrm{PO}_{4}$ \\
\hline 0,9 & 0,142 & 0,272 \\
\hline
\end{tabular}

Eletrodos de trabalho foram preparados com amostras dos materiais estudados, sendo estas embutidas em resina epóxi de cura a frio (Epofix), deixando-se uma das áreas livre para exposição ao meio de ensaio (Figura 14). Um fio de cobre foi fixado na parte posterior da amostra com cola de prata para permitir o contato elétrico. A superfície do eletrodo foi preparada por lixamento com papel de carbeto de silício até a grana \#2000 e posteriormente polida com pasta de diamante até $1 \mu \mathrm{m}$. Seguiu-se lavagem com acetona e água deionizada em cuba ultrassônica e posterior secagem com ar quente. Todos os testes eletroquímicos foram executados em uma célula de corrosão (Figura 15) com arranjo de três eletrodos, sendo usado o eletrodo de calomelano saturado (ECS) como referência e um fio de platina como contra eletrodo. 

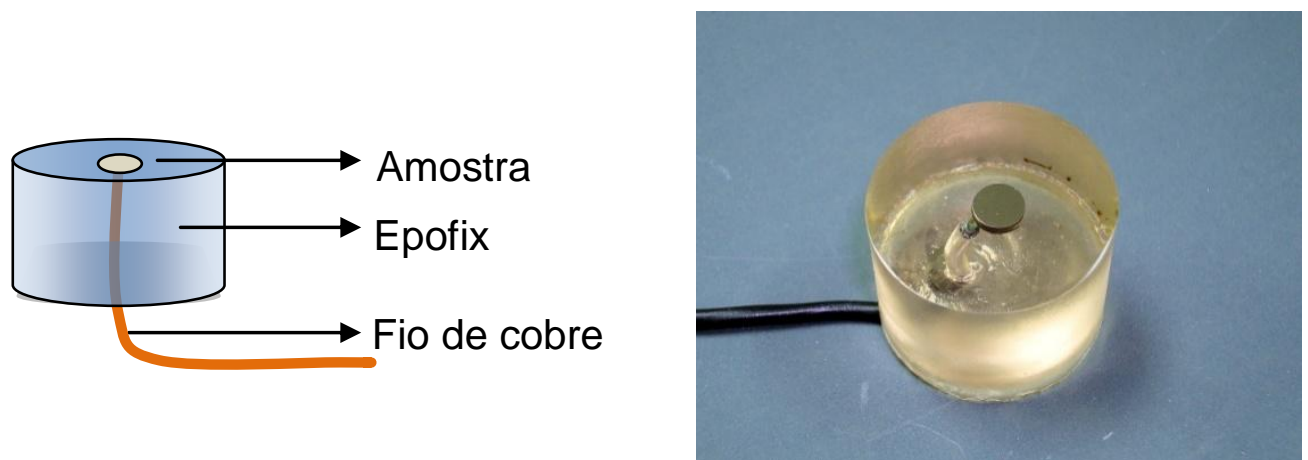

Figura 14 - Eletrodo de trabalho embutido em resina epóxi de cura a frio (Epofix)

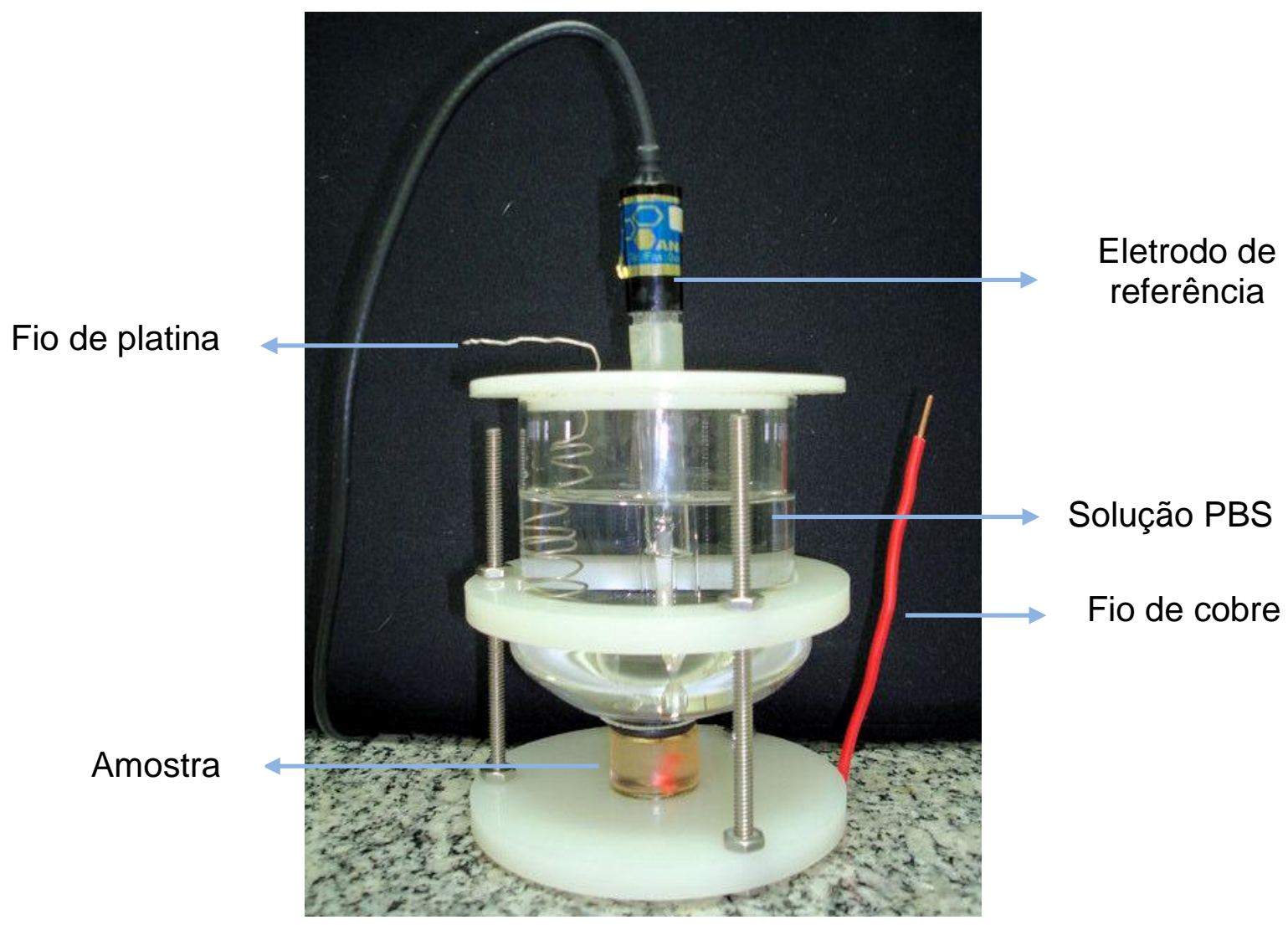

Figura 15 - Célula eletroquímica com arranjo de três eletrodos.

\subsubsection{Potencial de circuito aberto}

É importante estabelecer se o potencial de corrosão atingiu um estado estacionário, já que isto é necessário para a validação dos resultados de espectroscopia de impedância eletroquímica.

A variação do potencial em função do tempo foi monitorada para as amostras dos aços 17-4PH PIM, 1802, PM2000 e 316L, durante 24 horas, em solução PBS a $25^{\circ} \mathrm{C}$ naturalmente aerada. 


\subsubsection{Espectroscopia de Impedância Eletroquímica (EIE)}

Os três materiais experimentais e o aço $316 \mathrm{~L}$ foram investigados quanto ao comportamento eletroquímico, em função do tempo, em solução PBS a $25^{\circ} \mathrm{C}$. Os espectros de impedância foram obtidos após 2, 7, 14 e 21 dias de imersão. As medidas de EIE foram feitas no potencial de circuito aberto, utilizando-se um sinal senoidal com amplitude de $10 \mathrm{mV}$, na faixa de freqüências de $100 \mathrm{kHz}$ até $10 \mathrm{mHz}$ e taxa de aquisição de dados de 10 pontos por década. Utilizou-se um analisador de respostas em freqüência Solartron 1260 acoplado a um potenciostato Solartron 1287 (Figura 16).

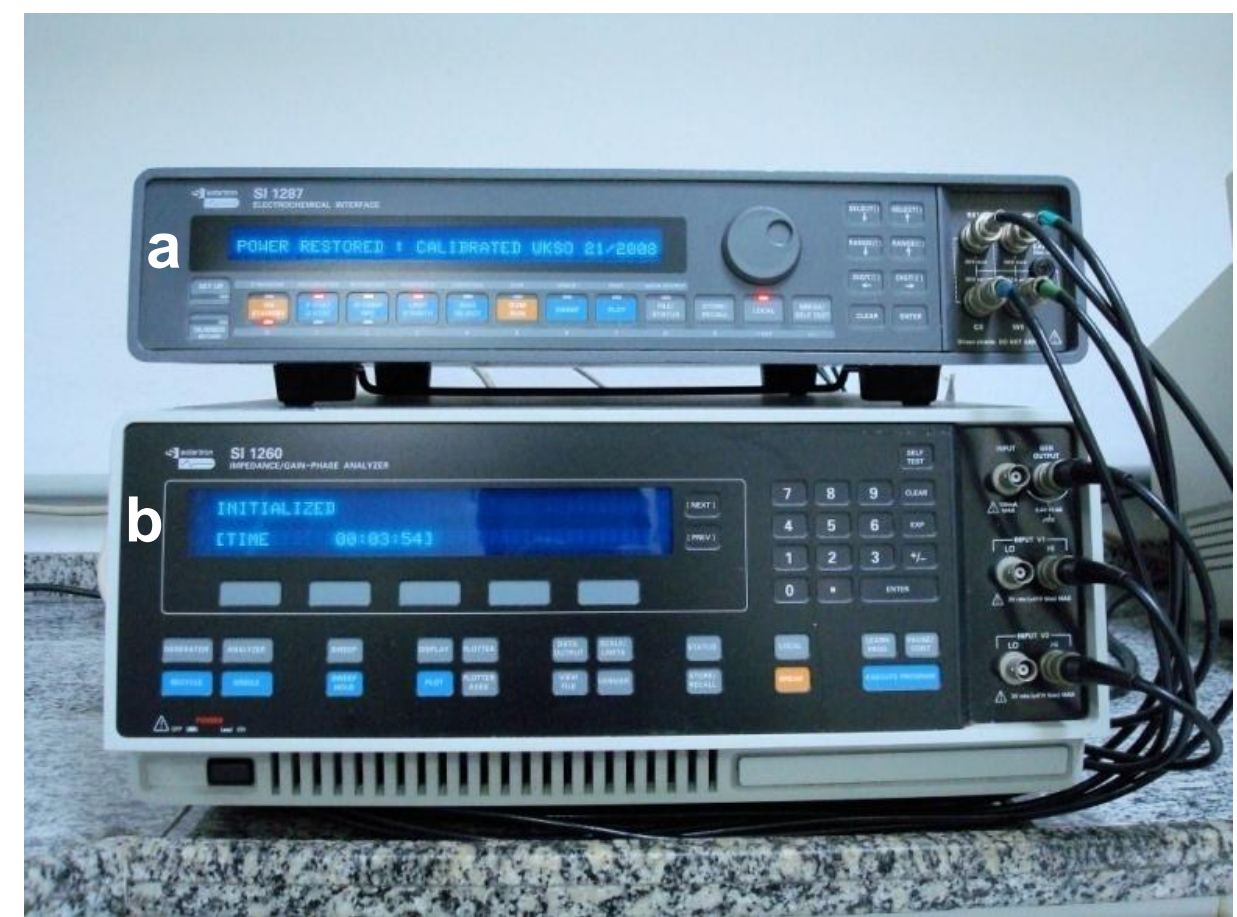

Figura 16 - Analisador de respostas em freqüência Solartron 1260 (b) acoplado a um potenciostato Solartron 1287 (a).

\subsubsection{Polarização anódica potenciodinâmica}

Curvas de polarização anódica foram obtidas potenciodinamicamente após dois dias de imersão em solução PBS a $25^{\circ} \mathrm{C}$, usando um potenciostato Solartron 1287. A faixa de polarização adotada foi do potencial de circuito aberto até se atingir a corrente limite de $10^{-3} \mathrm{~A} / \mathrm{cm}^{2}$ com taxa de varredura de $1 \mathrm{mV} / \mathrm{s}$.

\subsubsection{Polarização anódica "stair-step"}

As curvas de polarização anódica "stair-step" foram realizadas após dois dias de imersão em solução PBS a $25^{\circ}$ C, utilizando um potenciostato 
Solartron 1287. A polarização foi realizada do potencial de circuito aberto, adotando-se incrementos de $50 \mathrm{mV}$ a cada 300 segundos, até atingir uma densidade de corrente limite de $10^{-3} \mathrm{~A} / \mathrm{cm}^{2}$.

\subsubsection{Gráficos de Mott-Schottky - Propriedades eletrônicas do filme passivo}

A abordagem de Mott-Schottky foi utilizada para comparar as propriedades do filme passivo formado sobre amostras dos aços 316L e PM2000. Os eletrodos de trabalho foram embutidos em resina epóxi de cura a frio, deixando uma das áreas livre para exposição ao meio de ensaio. A superfície foi preparada por lixamento com papel de carbeto de silício, até grana \#2000, seguido por polimento com pasta de diamante até $1 \mu \mathrm{m}$. Foi feita imersão em solução PBS a 25ํ C e após 2, 6, 12 horas e 2, 7, 14 e 21 dias foram obtidos resultados experimentais.

Utilizou-se um equipamento Gamry PCl4/3000 para obtenção dos resultados utilizados nos gráficos de Mott-Schottky. As medidas foram realizadas na freqüência de $1 \mathrm{kHz}$, com aplicação da polarização em incrementos sucessivos de $-50 \mathrm{mV}_{\mathrm{ECS}}$ no sentido catódico, iniciando as medidas no potencial de $+250 m V_{\text {ECS }}$ até $-1000 m V_{E C S}$.

Pelos diagramas de Mott-Schottky foi obtida a concentração de dopantes $\mathrm{N}_{\mathrm{q}}$. Os valores de $\mathrm{N}_{\mathrm{q}}$ representam as densidades de doadores ou aceitadores de carga para um semicondutor tipo-n e tipo-p, respectivamente. Para o cálculo de $N_{q}$ empregaram-se os seguintes valores: $q=1,602.10^{-19} \mathrm{C} ; \varepsilon_{0}=$ $8,85.10^{-14} \mathrm{~F} . \mathrm{cm}^{2}$ (MARTINI e MULLER, 2000); $\varepsilon=12$ tanto para a camada passiva interna de óxido de cromo quanto para a externa rica em óxidos de ferro (AHN e KWON, 2004 e LOVRECEK e SEFAJA , 1972). Sabendo-se que, a inclinação da reta, verificada experimentalmente no gráfico de Mott-Schottky, corresponde aos termos $\frac{2}{s \Sigma_{0} \in N_{q}}$ da Equação 2, obtiveram-se os valores de $N_{q}$ para os doadores e aceitadores de cargas.

\subsubsection{Análise da composição química superficial por XPS}

Análises por XPS foram realizadas nas amostras dos aços PM2000, após imersão em solução PBS à 25ํㅡ por períodos de 2, 7, 14 e 21 dias. Os 
resultados obtidos desta técnica permitem obter a proporcionalidade relativa e os estados de oxidação dos elementos que constituem os filmes superficiais.

As análises de espectroscopia de fotoelétrons excitados por raios- $X$ foram realizadas em sistema da MICROLAB $310 \mathrm{~F}$ da $\mathrm{Vg}$ Scientific. Utilizou-se um anodo de $M g(K \alpha=1253,7 \mathrm{eV})$ com feixe não monocramatado e pressão de trabalho de $5 \times 10^{-9} \mathrm{mBar}$. 


\section{RESULTADOS E DISCUSSÕES}

\subsection{Citotoxicidade in vitro}

A Figura 8 mostra os resultados dos ensaios de citotoxicidade in vitro para os vários aços testados e controles positivo e negativo.

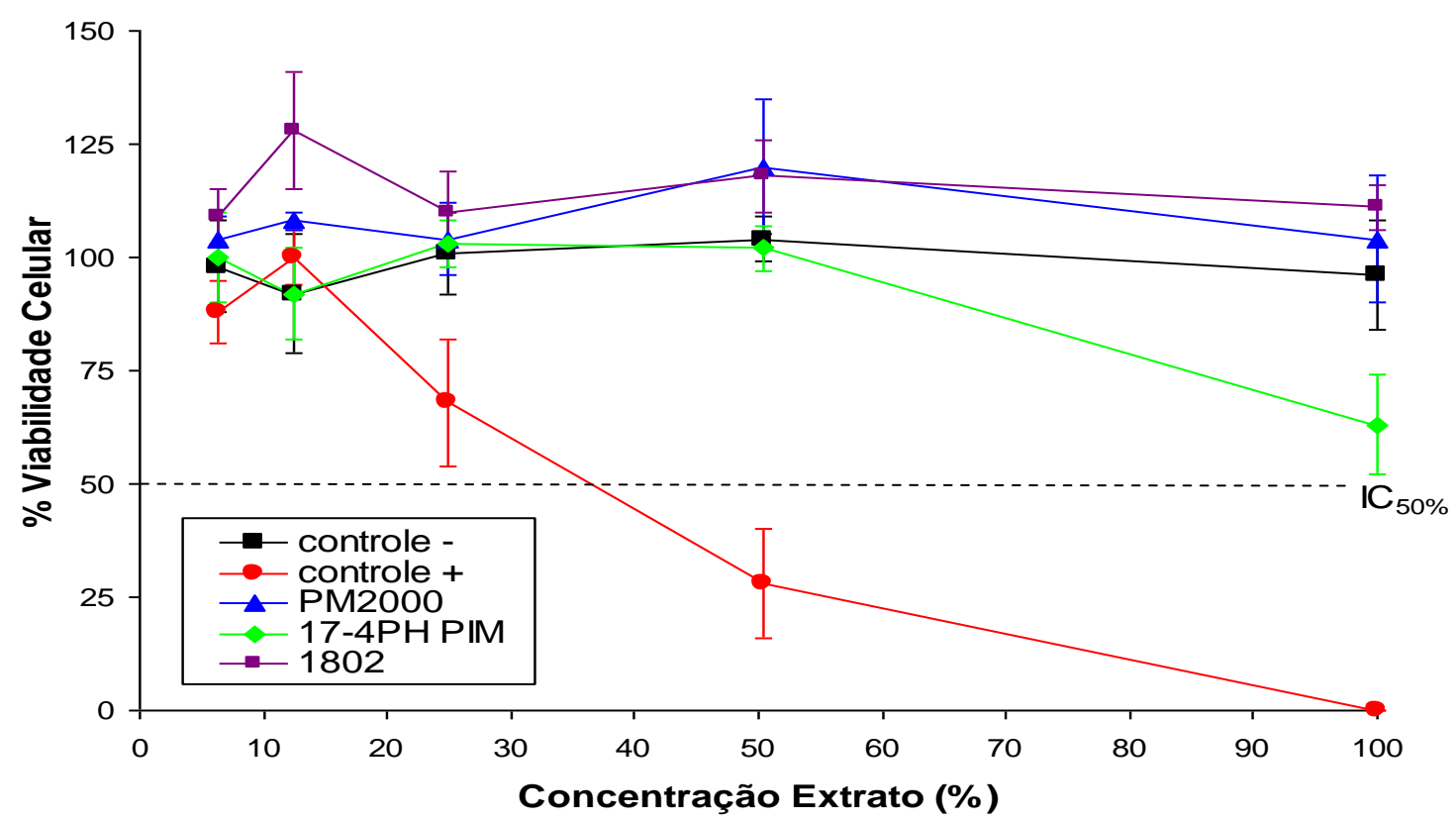

Figura 17 - Curvas de viabilidade celular pelo método de análise colorimétrica.

Pelo método de incorporação celular do corante supravital vermelhoneutro, pode-se observar que o PM2000, o 17-4PH PIM e o 1802 apresentaram comportamento similar ao controle negativo, ou seja, não revelaram tendência a provocar efeitos citotóxicos. As curvas de viabilidade celular, acima do índice de citotoxicidade $\mathrm{IC}_{50 \%}$, indicam que nenhum dos materiais testados apresentou efeito citotóxico pelo método adotado.

Estes resultados estão de acordo com trabalhos anteriores publicados na literatura sobre o aço 17-4PH PIM (COSTA et al., 2004) e o aço PM2000 (FLORES et al, 2004).

\subsection{Força de retenção magnética}

A força necessária para separar o imã das amostras é mostrada na Figura 18. O grupo controle obteve um valor médio $3439,7 \mathrm{gf} / \mathrm{cm}^{2}$, enquanto que o PM2000 obteve 4246,9 gf/cm², o 17-4PH PIM 5064,2 gf/cm² e o aço 18025074,3 $\mathrm{gf} / \mathrm{cm}^{2}$. Comparando-se os materiais experimentais com o grupo controle, todos apresentaram valores superiores, sendo que os aços 1802 e 17-4PH PIM obtiveram melhores resultados. 


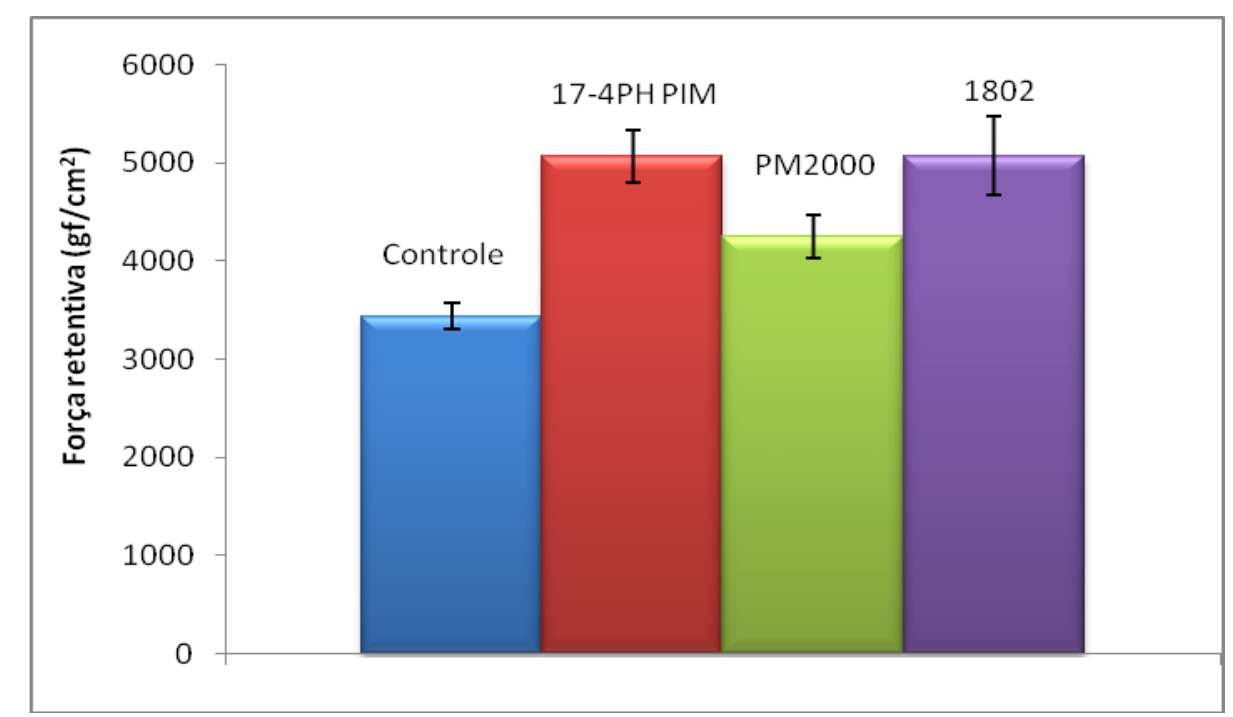

Figura 18 - Resultados da força de retenção magnética para as ligas testadas neste estudo e para o grupo controle.

A força de retenção magnética está diretamente relacionada à saturação de magnetização que, por sua vez, depende diretamente da quantidade de ferro na liga. Para verificar a relação entre a força de retenção magnética e a porcentagem em massa de ferro das amostras, foi desenhado um gráfico comparativo (Figura 19).

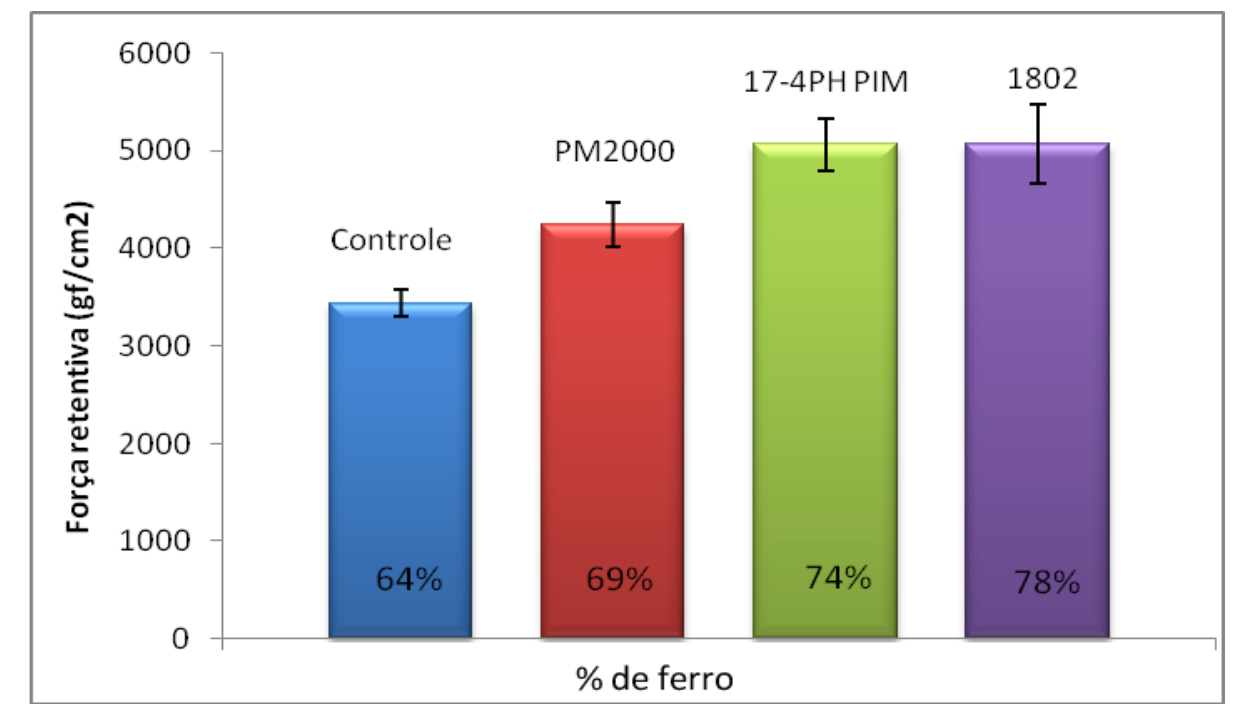

Figura 19 - Força retentiva magnética e \% Fe (em massa) associadas às ligas investigadas.

As amostras dos grupos experimentais e o grupo controle possuem porcentagens diferentes de ferro na composição de suas respectivas ligas. 0 comportamento ferromagnético foi proporcional à composição de ferro no material, o que significa que quanto maior teor de ferro na liga, maiores os valores de força retentiva magnética. 


\subsection{Potencial de circuito aberto}

As curvas de potencial de circuito aberto para os aços 316L, 1802, 174PH PIM e PM2000 em solução PBS, naturalmente aerada e a $25^{\circ} \mathrm{C}$, são mostradas na Figura 20. O período total de imersão foi de 24 horas.

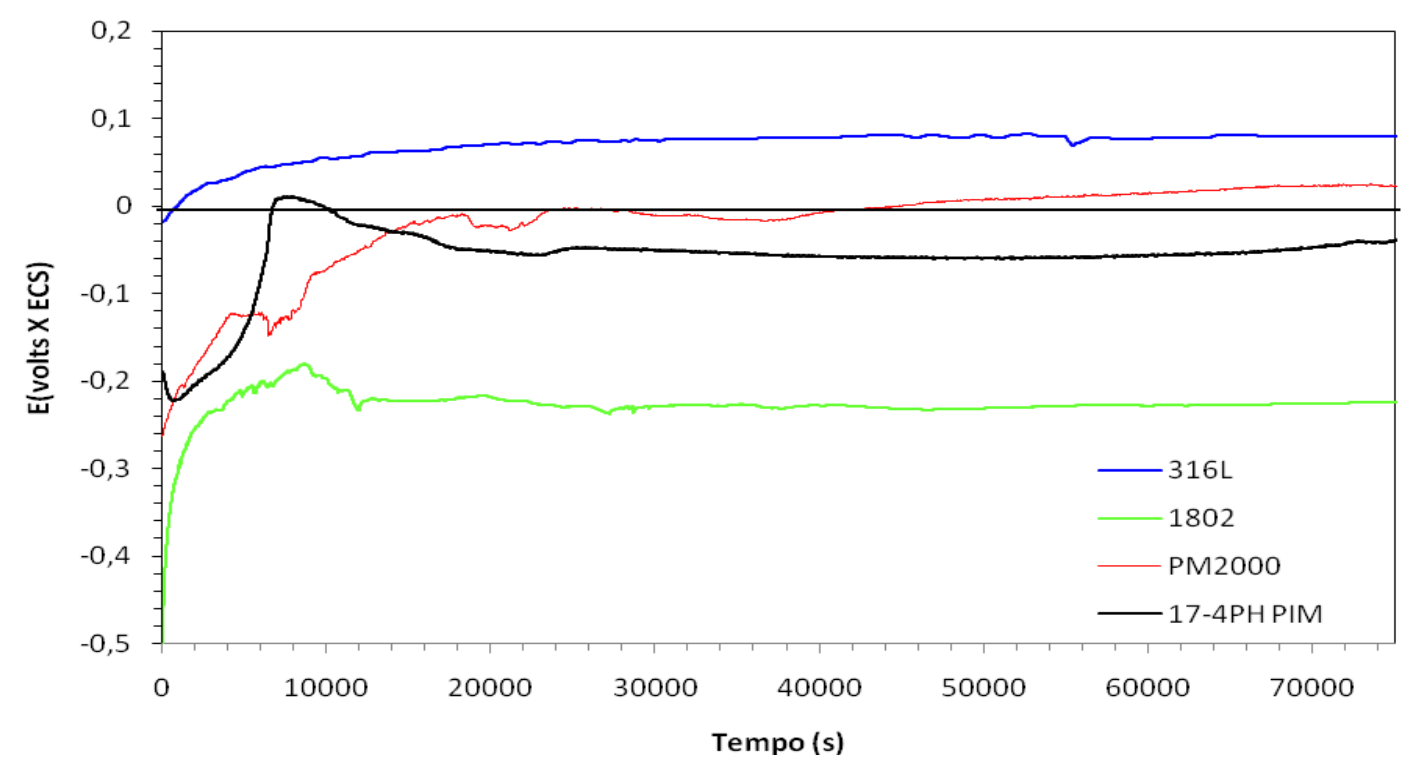

Figura 20 - Variação do potencial de circuito aberto ao longo do tempo de imersão em PBS naturalmente aerada à $25^{\circ} \mathrm{C}$.

A escolha da temperatura ambiente ( $\left.25^{\circ} \mathrm{C}\right)$ para a realização dos ensaios eletroquímicos, não influenciou nos resultados obtidos, pois em amostras previamente ensaiadas a $37^{\circ} \mathrm{C}$ obtiveram-se resultados semelhantes. A solução PBS a 25ㅇ C também foi utilizada por TERADA (2008) para ensaios eletroquímicos em aços inoxidáveis. A autora constatou que os resultados obtidos nesta temperatura não foram diferentes dos verificados a $37^{\circ} \mathrm{C}$. LAVOSVALERETO et al (2004) mostraram que, para ligas de titânio imersas em solução de Hanks, a variação de temperatura de $25^{\circ} \mathrm{C}$ para $37^{\circ} \mathrm{C}$ não produziu resultados divergentes.

Todos os materiais mostraram uma tendência de aumento do potencial no início da imersão. Isto pode ocorrer devido ao espessamento da camada de óxido no meio de ensaio. Em todas as curvas são observadas pequenas quedas de potencial que logo são restabelecidas. Este comportamento é devido aos defeitos intrínsecos da camada passiva superficial, ocasionando quebras localizadas, seguidas por repassivação destas.

Os potenciais de circuito aberto após a estabilização são mostrados na Tabela 5. Pelos valores obtidos, todos os materiais estabilizaram em potenciais 


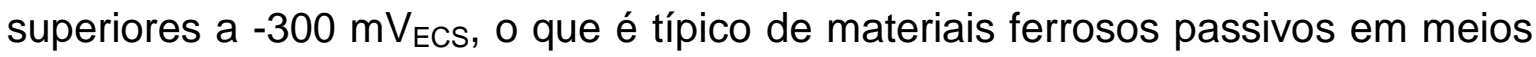
aquosos aerados. Os aços 316L, PM2000 e 17-4PH PIM estabilizaram em potenciais mais elevados, sendo que o $316 \mathrm{~L}$ obteve o potencial mais nobre, seguido pelo PM2000 e pelo aço 17-4PH PIM. O aço 1802 mostrou um potencial de estabilização bem inferior aos demais, o que sugere a presença de um óxido superficial menos protetor.

Tabela 5 - Potenciais de circuito aberto dos aços ensaiados, após estabilização.

\begin{tabular}{|c|c|}
\hline Aços & $\boldsymbol{E}\left(\mathbf{m V}_{\text {ECS }}\right)$ \\
\hline 316L & +80 \\
\hline PM2000 & +22 \\
\hline $17-4$ PH PIM & -40 \\
\hline 1802 & -224 \\
\hline
\end{tabular}

\subsection{Polarizações Anódicas}

\subsubsection{Técnica Potenciodinâmica}

A Figura 21 mostra as curvas de polarização anódica potenciodinâmica para os aços 316L, 1802, PM2000 e 17-4PH PIM após dois dias de imersão em solução PBS.

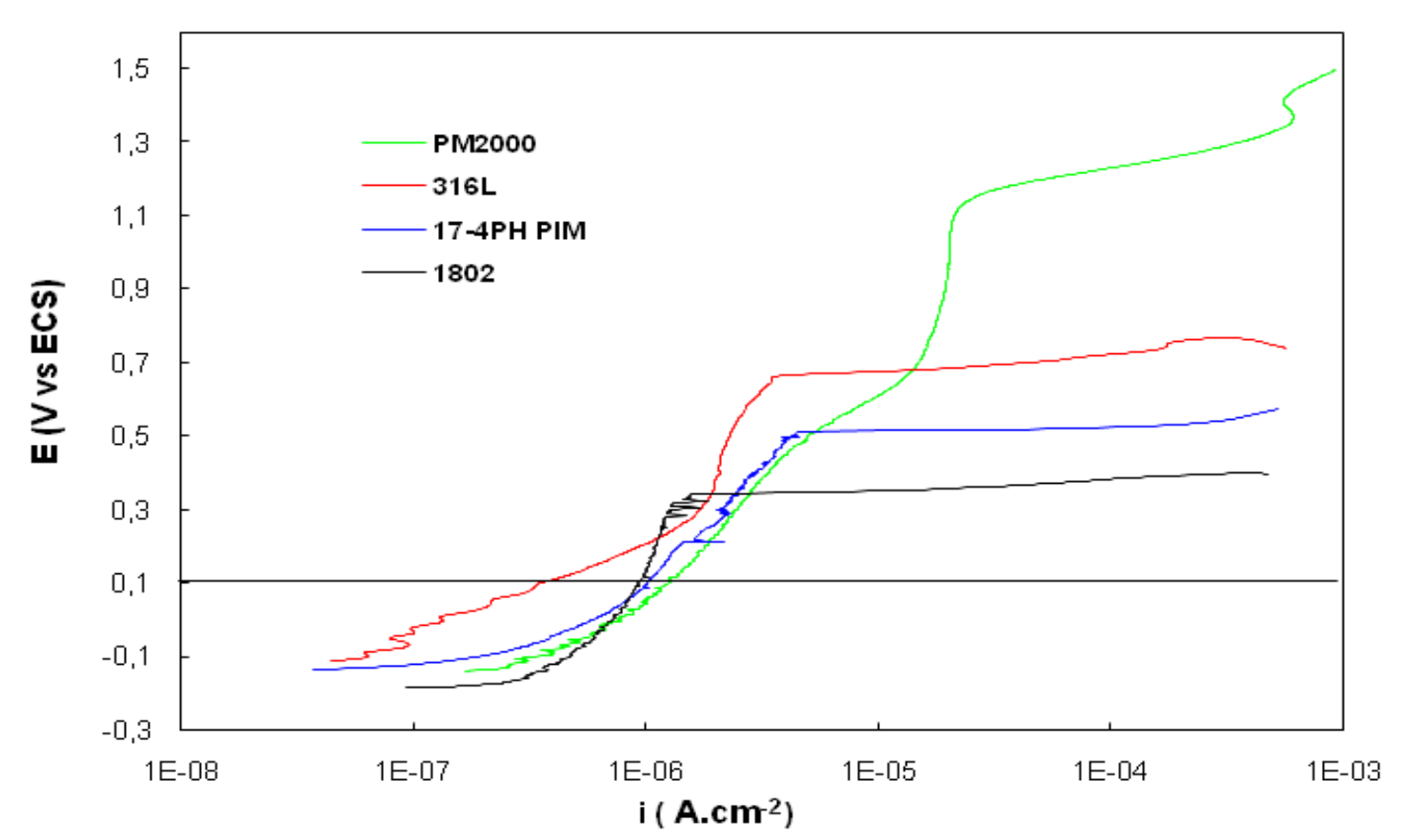

Figura 21 - Curvas de polarização anódica potenciodinâmica após dois de imersão em solução PBS naturalmente aerada à $25^{\circ} \mathrm{C}$. 
Com base nas curvas de polarização anódica potenciodinâmica, obtiveram-se os valores de potenciais de corrosão $\left(E_{\text {corr }}\right)$, correntes de corrosão $\left(i_{\text {corr }}\right)$ e potenciais de pite $\left(E_{\mathrm{p}}\right)$ para os aços inoxidáveis PM2000, 1802, 17-4PH PIM e 316L, conforme observado na Tabela 6.

Tabela 6 - Potenciais de corrosão, de pite e densidade de corrente de corrosão dos aços PM2000, 1802, 17-4PH PIM e 316L.

\begin{tabular}{|l|c|c|c|}
\hline \multicolumn{1}{|c|}{ Material } & $\boldsymbol{i}_{\text {corr }}\left(\mathrm{A} / \mathbf{c m}^{2}\right)$ & $E_{\text {corr }}\left(\mathbf{m V}_{\mathrm{ECS}}\right)$ & $E_{\mathrm{p}}\left(\mathrm{mV}_{\mathrm{ECS}}\right)$ \\
\hline PM2000 & $4,69 \mathrm{E}-07$ & -191 & +1151 \\
\hline $17-4 \mathrm{PH}$ PIM & $4,52 \mathrm{E}-07$ & -130 & +525 \\
\hline 1802 & $3,45 \mathrm{E}-07$ & -185 & +337 \\
\hline $316 \mathrm{~L}$ & $6,00 \mathrm{E}-08$ & -110 & +663 \\
\hline
\end{tabular}

As densidades de corrente de corrosão dos aços 17-4PH PIM, 1802 e PM2000 foram da ordem de $10^{-7} \mathrm{~A} / \mathrm{cm}^{2}$. O aço 316 $\mathrm{L}$ apresentou valores de $i_{\text {corr, }}$ uma ordem de grandeza inferior em relação aos outros aços. Apesar desta diferença, os baixos valores obtidos mostram que todos os materiais estão passivos no meio de ensaio. O comportamento passivo foi observado em uma ampla faixa de potenciais que variou dependendo do material testado. Ao redor

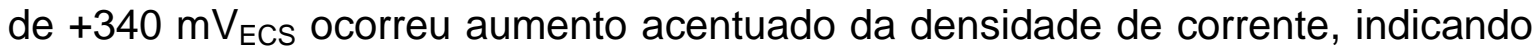
quebra do filme e formação de pite no aço 1802. Na micrografia da Figura 22A pode-se observar o pite formado nesta amostra.

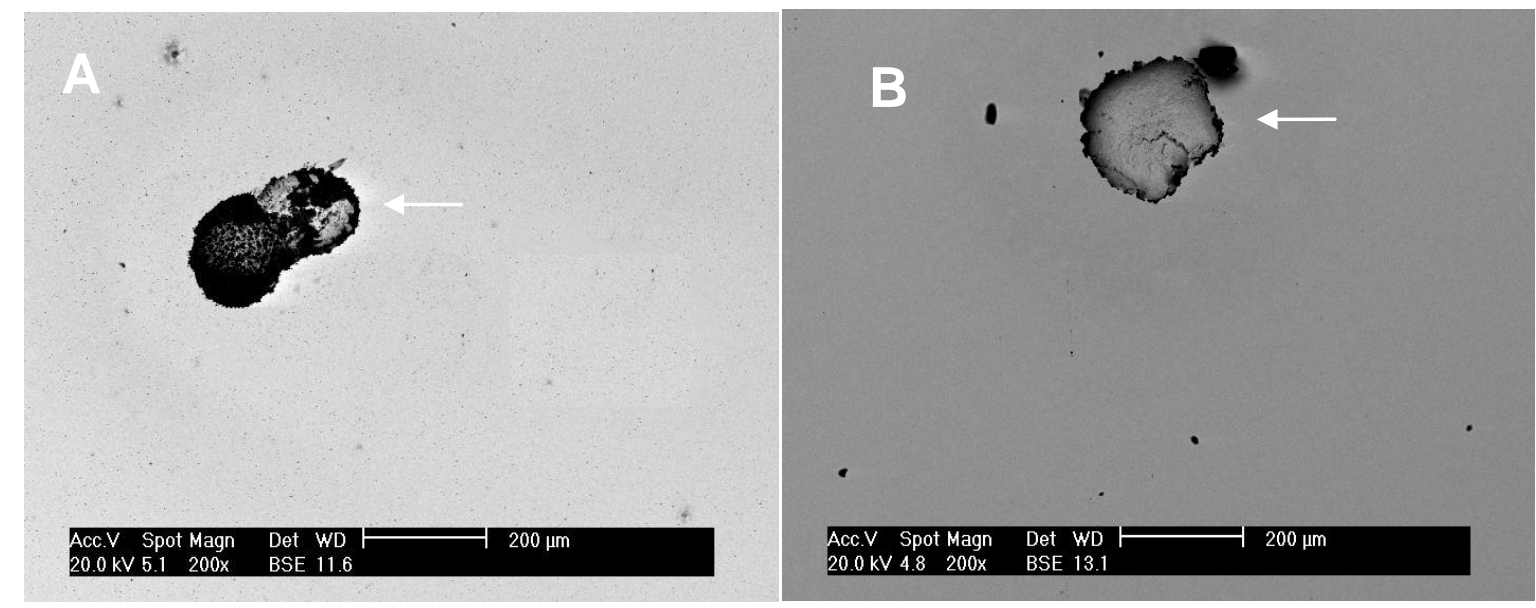

Figura 22 - Micrografias obtidas por MEV das amostras polarizadas anodicamente pela técnica potenciodinâmica, após 2 dias de imersão em solução PBS à $25^{\circ} \mathrm{C}$; A) aço 1802; B) aço 316L 
Para o aço 316L, o aumento na densidade de corrente ocorreu no potencial de $+680 \mathrm{mV}_{\mathrm{ECS}}$, e o pite formado pode ser observado na Figura 22(B). $\mathrm{O}$ aumento de corrente ocorreu para o aço 17-4 PH PIM em potenciais próximos de

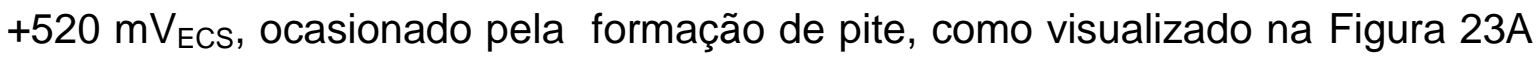
(seta preta). Como característica do processo de fabricação desta liga (metalurgia do pó) tem-se a presença de poros na amostras. Alguns destes poros estão indicados pelas setas brancas na micrografia da Figura 23A. No interior do pite observou-se a presença de grânulos de óxido de silício (analisados por espectroscopia por energia dispersiva - EDS - Figura 24), indicados na Figura 23B (setas brancas). Em algumas regiões, ocorreu o destacamento destas partículas deixando pequenas cavidades (Figura 23B, setas pretas).
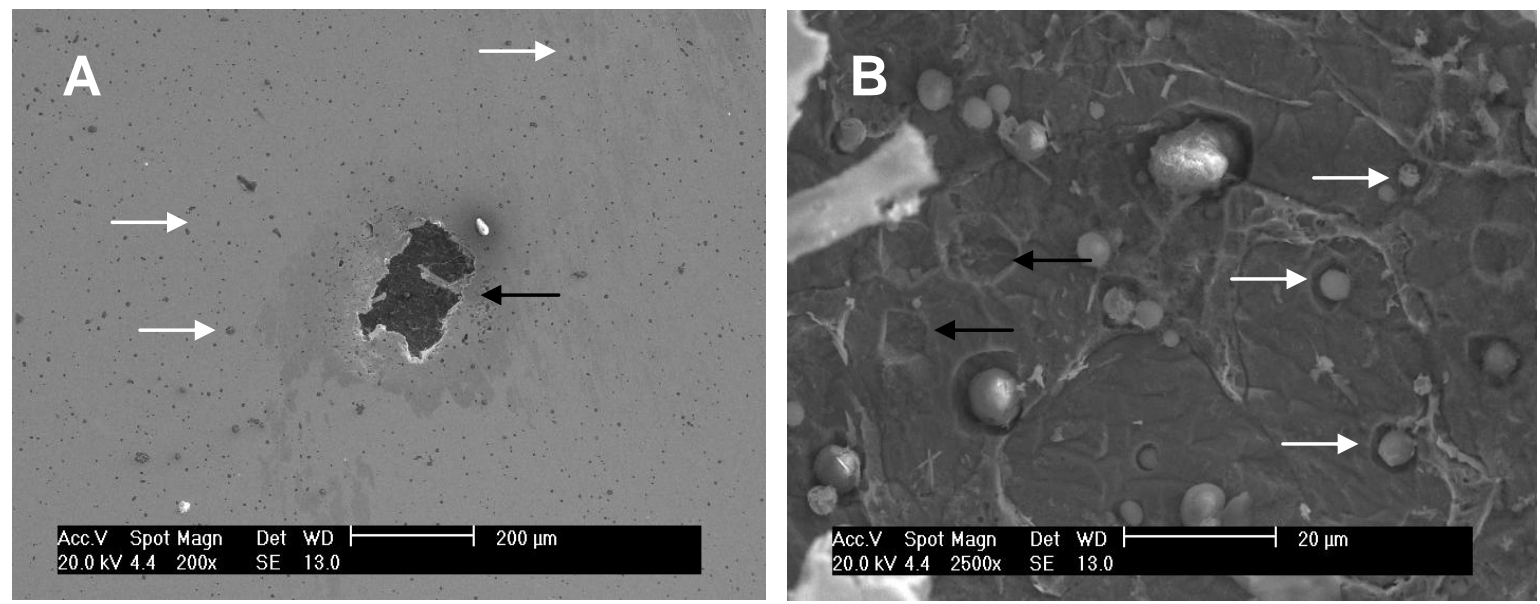

Figura 23 - Micrografias obtidas por MEV das amostras do aço 17-4PH PIM, polarizadas anodicamente pela técnica potenciodinâmica, após 2 dias de imersão em solução PBS à $25^{\circ} \mathrm{C}$; A) vista geral; B) região interna ao pite.

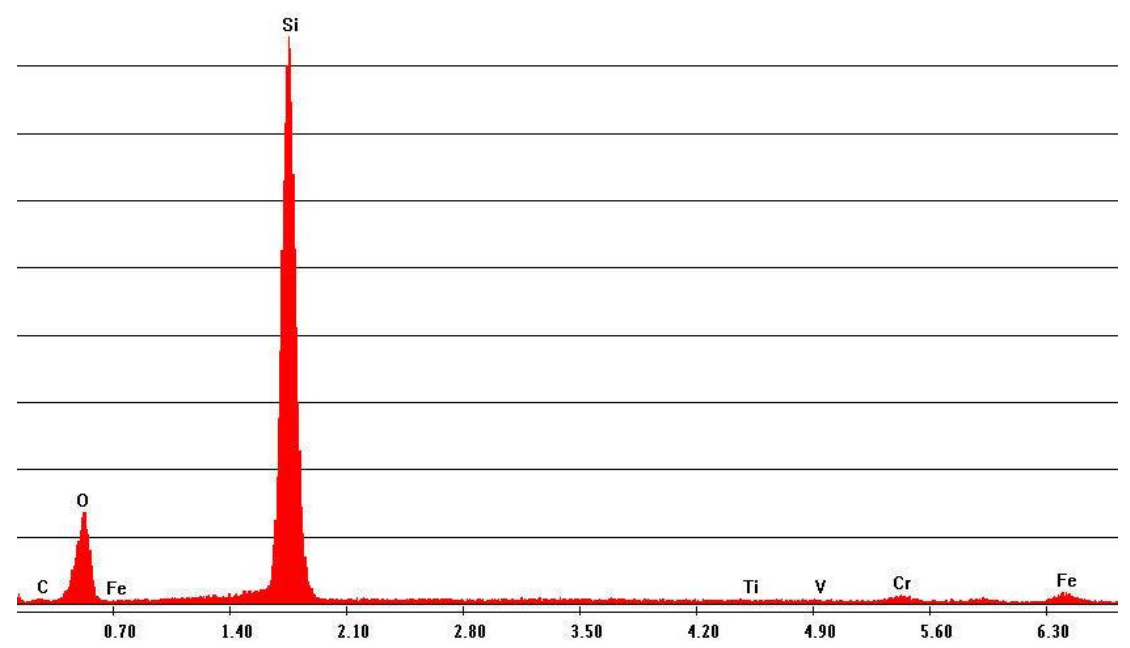

Figura 24- EDS da amostra do aço 17-4PH PIM após polarização. 
$\mathrm{Na}$ curva de polarização anódica da amostra do aço PM2000, o aumento na densidade de corrente foi detectado em $+1150 \mathrm{mV}_{\mathrm{ECS}}$. Como em potenciais próximos a $+1100 \mathrm{mV}_{\mathrm{ECS}}$ ocorre a reação de evolução de oxigênio, o aumento de corrente observado só pode ser associado à formação de pites após observação da superfície da amostra e identificação do pite. A Figura 25(A) mostra a presença de pequenos pites com diâmetro inferior a $2 \mu \mathrm{m}$. Isto confirma que o aumento na densidade de corrente está associado à nucleação de pites. Em uma micrografia com maior aumento (Figura 25), observa-se a presença de pequenos poros da liga (setas brancas) e dos pites formados (setas pretas).
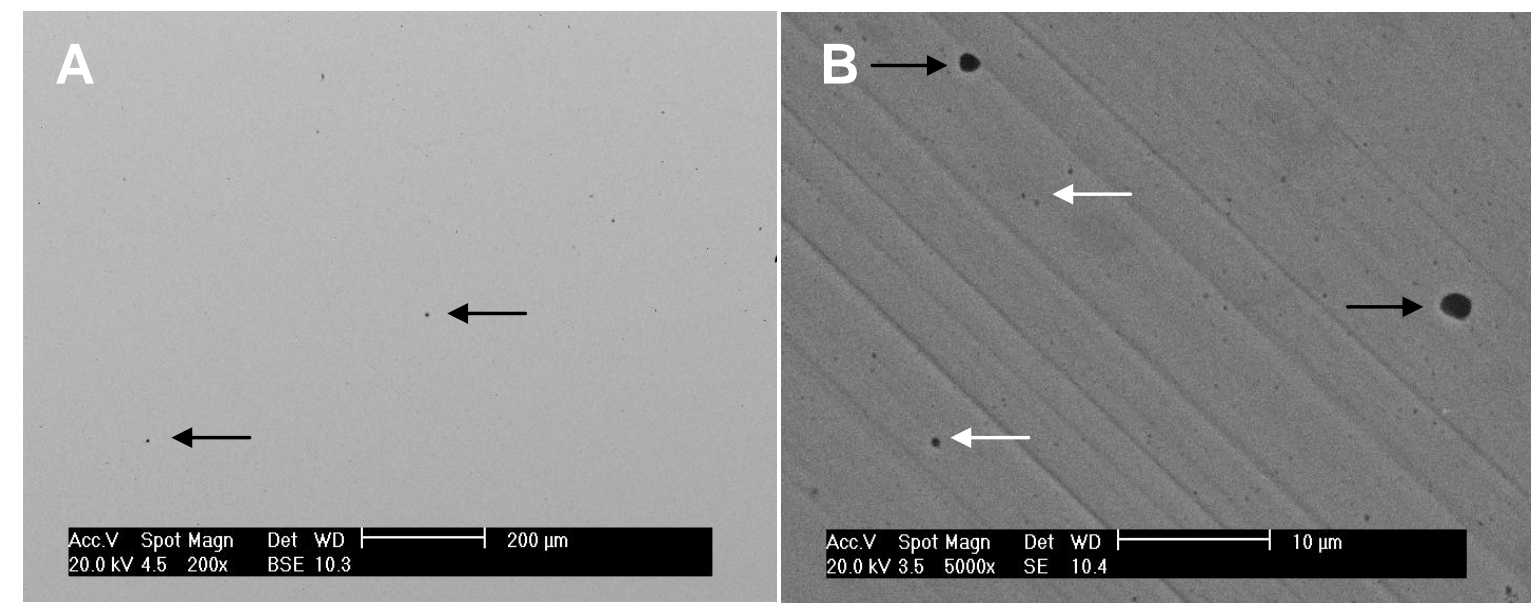

Figura 25 - Micrografias obtidas por MEV das amostras do aço PM2000, polarizadas anodicamente pela técnica potenciodinâmica, após 2 dias de imersão em solução PBS à 25두 pites (setas pretas) e poros (setas brancas) na superfície da liga em maior aumento.

Pelos valores de potenciais de pite obtidos, o aço PM2000 foi o único que obteve valores superiores ao 316L. Os aços 17-4PH PIM e 1802 apresentaram $E_{p}$ inferiores ao aço 316L, usado como referência. Estes resultados indicam que o aço com maior resistência à corrosão por pite foi o PM2000, seguido pelo 316L e o 17-4PH PIM. Segundo os dados obtidos, o aço 1802 foi o que apresentou menor resistência à corrosão por pite.

\subsubsection{Técnica "stair-step"}

Com o objetivo de obter o potencial de pite em condições de maior estacionariedade em relação às do ensaio potenciodinâmico, foi empregada a técnica de polarização anódica "stair-step" que é uma técnica potenciostática. 
A nucleação de pites é um fenômeno estocástico, que ocorre com maior probabilidade quanto mais perto do potencial de quebra da camada passiva o material se encontra. Com incrementos de $50 \mathrm{mV}_{\mathrm{ECS}}$ a cada $300 \mathrm{~s}$, a variação de potencial é mantida por um período maior, o que aumenta a probabilidade de nucleações de pites e permite definir com maior precisão se a faixa de potencial aplicado está, ou não, na faixa de potencial passivo dos materiais.

As curvas de polarização anódicas "stair-step" foram obtidas para 2 dias de imersão em solução PBS naturalmente aerada e a 25을 e estas são mostradas na Figura 26.

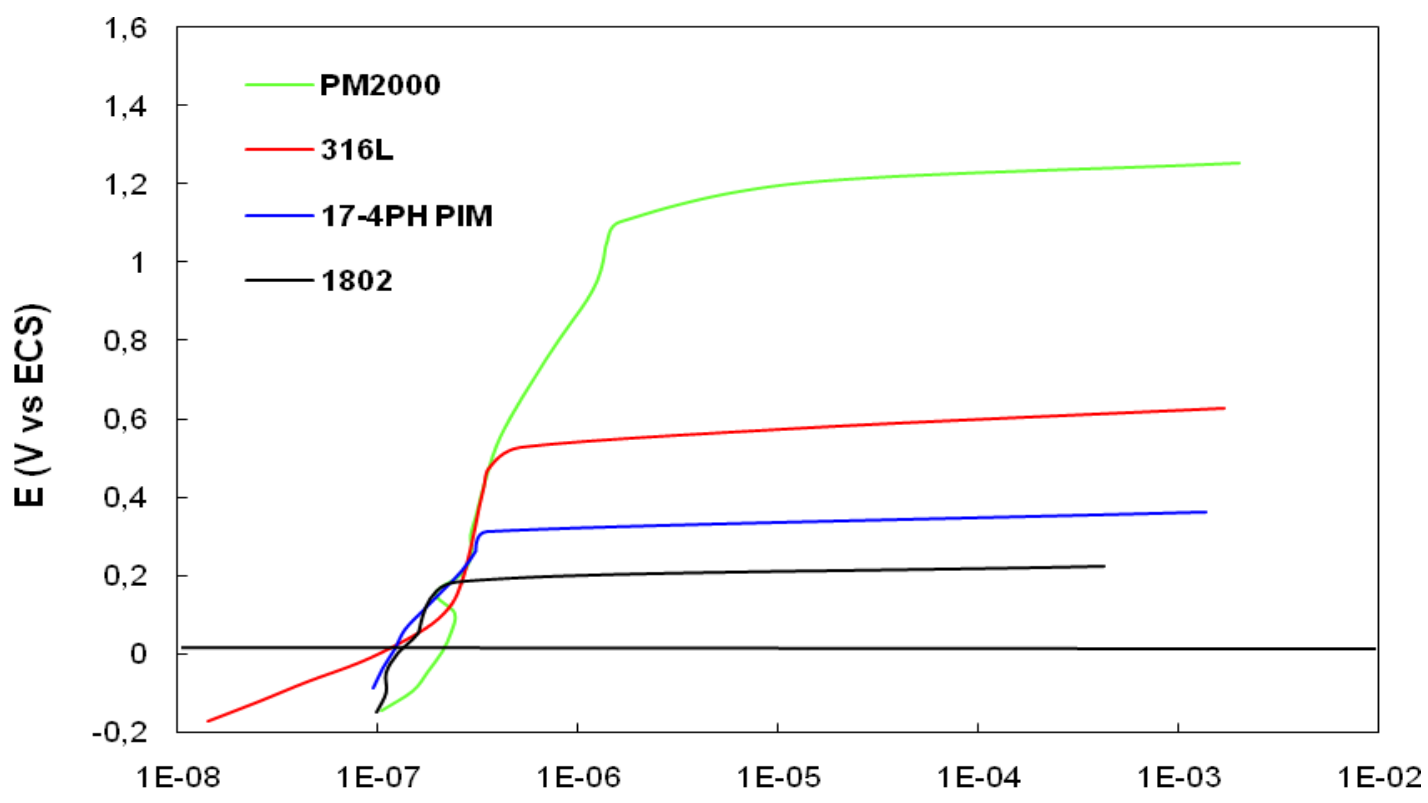

i $\left(\right.$ A. $\left.\mathrm{cm}^{-2}\right)$

Figura 26 - Curvas de polarização anódica obtidas pelo método "stair-step" para 2 dias de imersão em solução PBS naturalmente aerada e a 25으.

Com base nas curvas de polarização obtiveram-se os valores de potenciais de corrosão ( $\left.E_{\text {corr }}\right)$, correntes de corrosão $\left(i_{\text {corr }}\right)$ e potenciais de pite $\left(E_{\mathrm{p}}\right)$ para os aços inoxidáveis PM2000, 1802, 17-4PH PIM e 316L, conforme observado na Tabela 7. 
Tabela 7 - Potenciais de corrosão, de pite e densidade de corrente de corrosão dos aços PM2000, 1802, 17-4PH PIM e 316L.

\begin{tabular}{|l|c|c|c|}
\hline \multicolumn{1}{|c|}{ Material } & $\boldsymbol{I}_{\text {corr }}\left(\mathbf{A} / \mathbf{c m}^{2}\right)$ & $\boldsymbol{E}_{\text {corr }}\left(\mathbf{m V}_{\mathrm{ECS}}\right)$ & $\boldsymbol{E}_{\mathrm{p}}\left(\mathbf{m V}_{\mathrm{ECS}}\right)$ \\
\hline PM2000 & $1,45 \mathrm{E}-07$ & -145 & +1104 \\
\hline $17-4 \mathrm{PH}$ PIM & $1,06 \mathrm{E}-07$ & -86 & +313 \\
\hline 1802 & $1,10 \mathrm{E}-07$ & -144 & +184 \\
\hline $316 \mathrm{~L}$ & $2,53 \mathrm{E}-08$ & -170 & +529 \\
\hline
\end{tabular}

Os aços PM2000, 17-4PH PIM e 1802 apresentaram densidades de corrente de corrosão ( $i_{\text {corr }}$ ) próximas a $10^{-7} \mathrm{~A} / \mathrm{cm}^{2}$. O aço $316 \mathrm{~L}$ revelou uma $i_{\text {corr }}$ cerca de uma ordem de grandeza inferior aos demais. Apesar desta diferença de uma ordem de grandeza, todos os materiais apresentaram uma taxa de corrosão extremamente baixa, indicando, portanto, condição passiva.

Em todas as curvas, a quebra da camada passiva foi bem evidente, e caracterizada por um aumento abruto da densidade de corrente no potencial de pite $E_{\mathrm{p}}$. No aço $\mathrm{PM} 2000 \circ E_{\mathrm{p}}$ foi ao redor de $+1100 \mathrm{mV}_{\mathrm{ECS}}$, sendo o único que superou o potencial de pite do aço $316 \mathrm{~L}$ utilizado como controle. Em potenciais de aproximadamente $+180 \mathrm{mV}_{\mathrm{ECS}} \mathrm{O}$ aço 1802 apresentou um grande aumento na corrente em decorrência da formação de pite (Figura 29A). Já para o aço 17-4PH PIM o potencial de pite (Figura 28) foi de cerca de $+310 \mathrm{mV}_{\mathrm{ECS}} \mathrm{e}$, portanto, inferior ao 316L. Os resultados mostraram que $\circ E_{p}$ do 1802 foi o menor entre os materiais ensaiados, indicando que este material apresenta a menor resistência à corrosão localizada entre os testados.

As amostras polarizadas foram examinadas por microscopia eletrônica de varredura (MEV), para observação da morfologia e tamanho dos pites. $\mathrm{Na}$ Figura 27, tem-se a micrografia do aço PM2000, evidenciando a formação de um

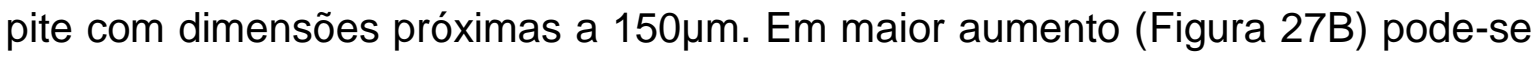
observar que ocorreu corrosão entre as camadas da liga. 

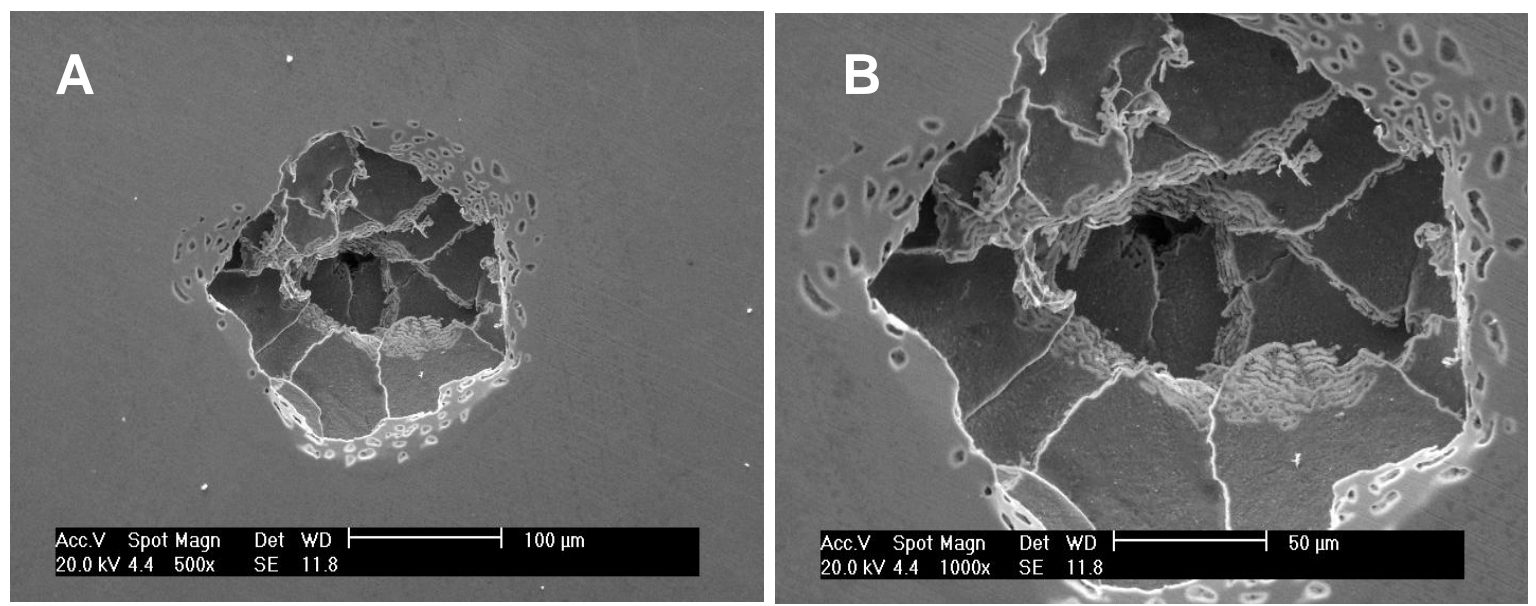

Figura 27 - Micrografia obtida por MEV da amostra do aço PM2000 polarizada anodicamente pela técnica "stair-step", após 2 dias de imersão em solução PBS a $25 \stackrel{\circ}{ } \mathrm{C}$; A) aumento de 500X; B) aumento de 1000X.

Na Figura 28A, a micrografia do aço 17-4PH PIM mostra a presença de um pite e de uma infinidade de pequenos pontos pretos (indicados por setas), que são as porosidades da liga. Em um maior aumento do interior do pite (Figura 28B), pode-se observar uma grande quantidade de pequenos grânulos de óxido de silício dentro do pite, sendo alguns destes indicados por setas.
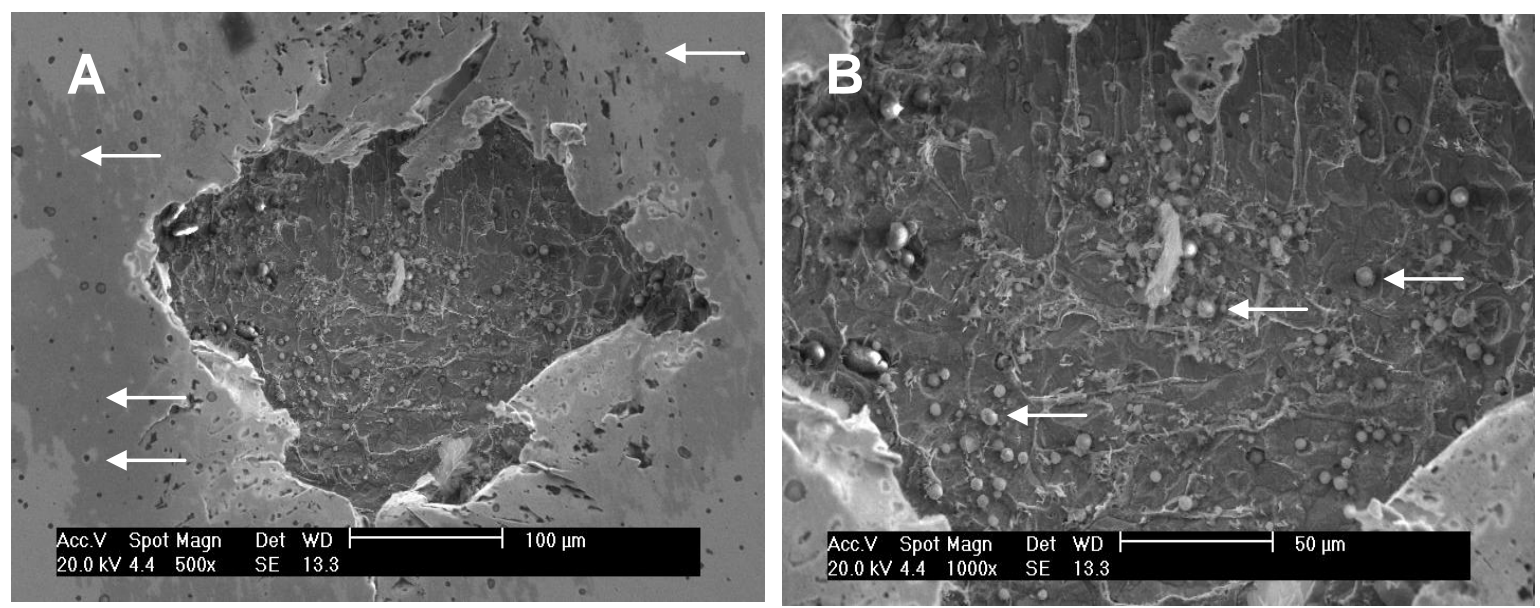

Figura 28 - Micrografias obtidas por MEV da amostra do aço 17-4PH PIM polarizada anodicamente pela técnica stair-step, para 2 dias de imersão em solução PBS a 25C; A) Aumento de 500X; B) Aumento de 1000X.

A superfície do aço 1802, após a polarização, é observada na Figura 29A. Na Figura 29B tem-se um maior aumento do pite indicado pela seta. 

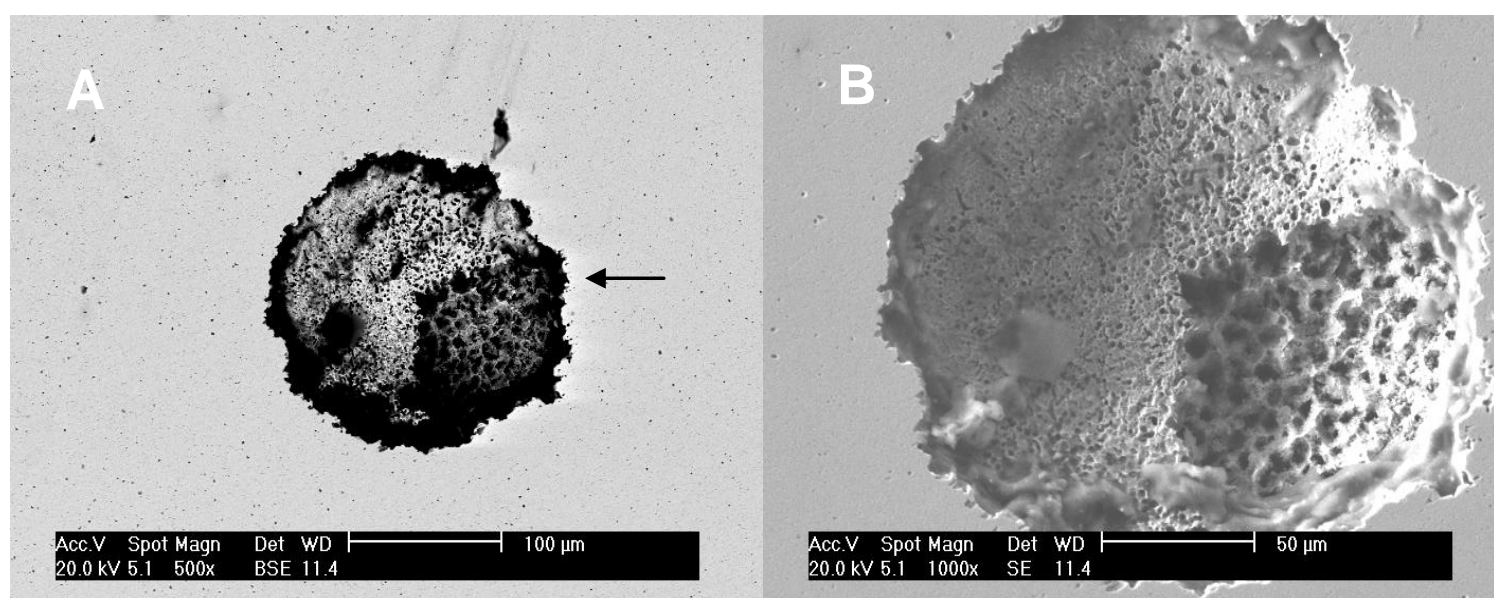

Figura 29 - Micrografias obtidas por MEV de amostras do aço 1802 polarizada anodicamente pela técnica stair-step, após 2 dias de imersão em solução PBS à 25ํㅜ ; A) Elétrons secundários; B) Elétrons retroespalhados.

\subsubsection{Técnica Stair-Step versus Técnica Potenciodinâmica}

$\mathrm{Na}$ Tabela 8 são mostrados os valores dos potenciais de pite $\left(E_{\mathrm{p}}\right) \mathrm{e}$ densidades de correntes de corrosão $\left(i_{\text {corr }}\right)$ obtidos das curvas de polarização anódica potenciodinâmica e "stair-step", para os aços inoxidáveis PM2000, 1802, 17-4PH PIM e 316L.

Tabela 8 - Potenciais de pite $\left(E_{\mathrm{p}}\right)$ e densidades de corrente de corrosão $\left(i_{\text {corr }}\right)$ dos aços inoxidáveis PM2000, 1802, 17-4PH PIM e 316L, obtidos dos resultados das técnicas de polarização anódica potenciodinâmica e polarização anódica "stairstep".

\begin{tabular}{|l|c|c|c|c|}
\hline \multirow{2}{*}{ Material } & \multicolumn{2}{|c|}{ Potenciodinâmica } & \multicolumn{2}{c|}{ "Stair-step" } \\
\hline & $\boldsymbol{i}_{\text {corr }}\left(\mathbf{A} / \mathbf{c m}^{2}\right)$ & $\boldsymbol{E}_{\mathrm{p}}\left(\mathbf{m V}_{\mathbf{E C S}}\right)$ & $\boldsymbol{i}_{\text {corr }}\left(\mathbf{A} / \mathbf{c m}^{2}\right)$ & $\boldsymbol{E}_{\mathbf{p}}\left(\mathbf{m V}_{\text {Ecs }}\right)$ \\
\hline PM2000 & $4,69 \mathrm{E}-07$ & +1151 & $1,45 \mathrm{E}-07$ & +1104 \\
\hline $17-4 \mathrm{PH}$ PIM & $4,52 \mathrm{E}-07$ & +525 & $1,06 \mathrm{E}-07$ & +313 \\
\hline 1802 & $3,45 \mathrm{E}-07$ & +337 & $1,10 \mathrm{E}-07$ & +184 \\
\hline 316L & $6,00 \mathrm{E}-08$ & +663 & $2,53 \mathrm{E}-08$ & +529 \\
\hline
\end{tabular}

Os resultados obtidos pelas técnicas de polarização anódica potenciodinâmica e "stair-step" confirmaram que o aço PM2000 foi o único que apresentou potencial de pite superior ao aço AISI 316L, utilizado como referência. O aço 17-4PH PIM apresentou $E_{\mathrm{p}}$ pela técnica potenciodinâmica um pouco inferior ao 316L, porém, pela técnica "stair-step" esta diferença se acentuou. 0 
aço 17-4PH PIM possui maior tendência à corrosão por pite que o material de referência. Em ambas as técnicas, o aço Sandvik 1802 revelou um $E_{\mathrm{p}}$ significativamente inferior ao do 316L.

Pelos resultados obtidos por ambas as técnicas, os valores de $E_{\mathrm{p}}$ da polarização anódica potenciodinâmica foram, para todas as amostras, mais elevados que os potenciais de pite da polarização anódica "stair-step". O que pode ter influenciado nestes resultados é a taxa de varredura de cada técnica, uma vez que os incrementos de potencial foram mais lentos na técnica "stair-step" em comparação com a potenciodinâmica.

Para os resultados de densidades de corrente de corrosão ( $\left.i_{\text {corr }}\right)$, o aço $316 \mathrm{~L}$ obteve valores da ordem de $10^{-8} \mathrm{~A} / \mathrm{cm}^{2}$ em ambas as técnicas de polarização, sendo uma ordem de grandeza inferior que os demais materiais. Para os três materiais experimentais, a $i_{\text {corr }}$ foi da ordem de $10^{-7} \mathrm{~A} / \mathrm{cm}^{2}$. Mesmo com esta diferença de uma ordem de grandeza, todos os aços apresentaram taxa de corrosão típica de materiais passivos.

\subsection{Ensaios de Espectroscopia de Impedância Eletroquímica (EIE)}

\subsubsection{Aço 1802}

$\mathrm{Na}$ Figura 30 são mostrados os diagramas de impedância do aço 1802 após 2, 714 e 21 dias de imersão em solução PBS naturalmente aerada e a $25^{\circ} \mathrm{C}$.

Os diagramas de Bode (ângulo de fase) mostrados na Figura 30a, revelam que o aço 1802 apresenta comportamento capacitivo com ângulos de fase entre $-60^{\circ}$ e $-70^{\circ}$ nas regiões de baixa freqüência. Este comportamento é típico de metais passivos, como observado por PÉREZ et al. (2002) para o aço 316L. O formato dos diagramas apresentou pequena variação em função do período de imersão. Após o segundo dia, observou-se um aumento do valor do ângulo de fase em baixa freqüência que foi de $-60^{\circ}$ para valores próximos a $-70^{\circ}$ e aumento de impedância com o tempo de imersão entre 2 e 21 dias de imersão. Estes resultados indicam que a camada passiva do aço inoxidável torna-se mais protetora com o tempo de imersão no meio de ensaio. Observa-se a presença de duas constantes de tempo, a primeira associada ao pico em cerca de $100 \mathrm{~Hz}$, e a segunda relacionada ao pico em freqüências inferiores a $0,1 \mathrm{~Hz}$. Os valores do 
módulo de impedância (Figura 30b) mantiveram-se praticamente constantes durante todos os períodos, sendo da ordem de $10^{5} \Omega . \mathrm{cm}^{2}$ a $0,01 \mathrm{~Hz}$.
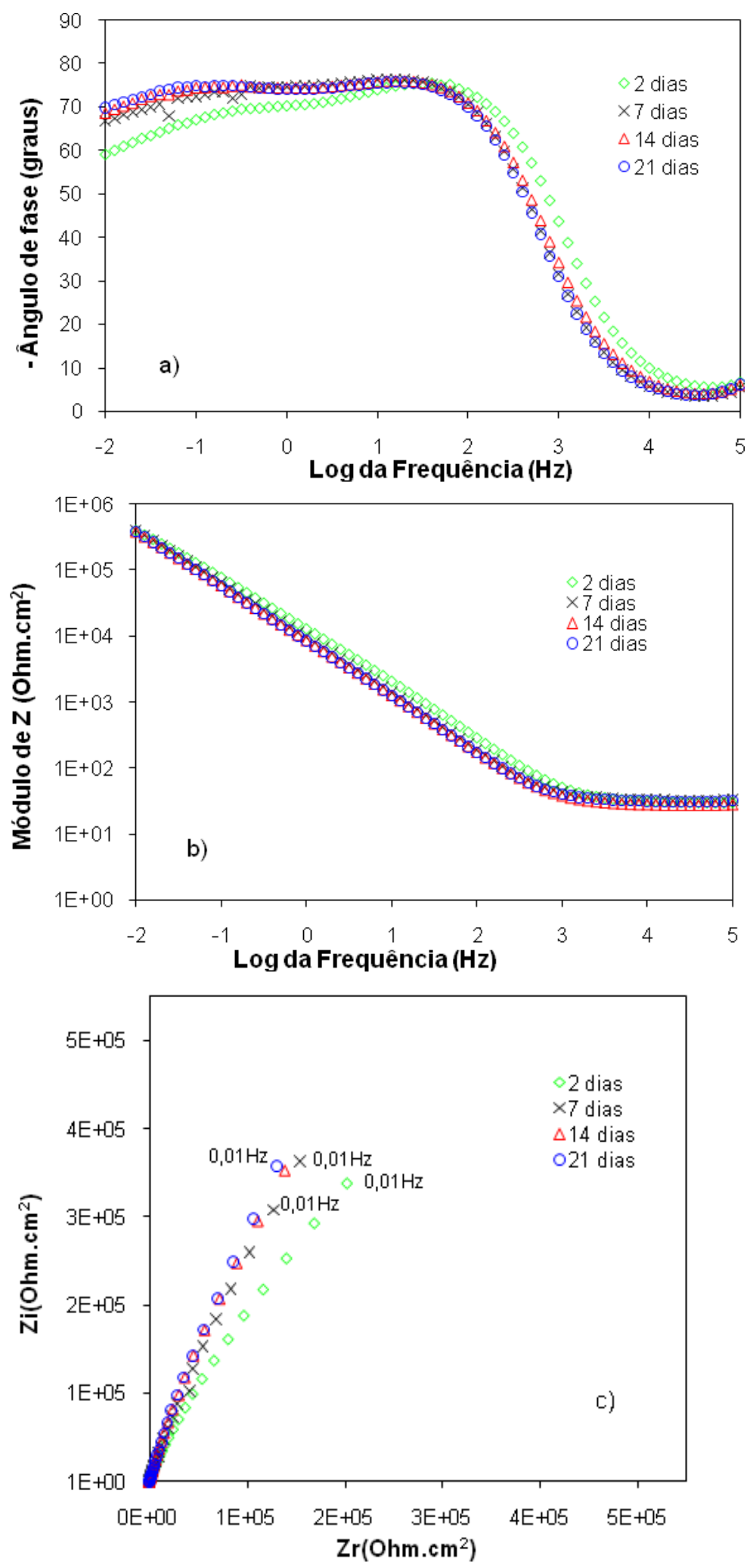

Figura 30 - Diagramas de impedância do aço 1802 em solução PBS naturalmente aerada e à 25ํㅡ: (a) Bode (Ângulo de fase); (b) Bode (Módulo de Z); (c) Nyquist. 
Os diagramas de Nyquist (Figura 30c) são caracterizados por um início de arco capacitivo, com elevadas impedâncias nas baixas freqüências (ordem de $10^{5} \Omega . \mathrm{cm}^{2}$ a $0,01 \mathrm{~Hz}$ ) em todos os períodos de imersão. Entre dois e sete dias de imersão observa-se um pequeno aumento da impedância, tornando-se mais capacitiva, e esta se manteve praticamente constante no decorrer do ensaio.

\subsubsection{Aço PM2000}

Na Figura 31 são mostrados os diagramas de impedância do aço PM2000 após 2, 7, 14 e 21 dias de imersão, em solução PBS naturalmente aerada e a $25^{\circ} \mathrm{C}$.

Os diagramas de Bode (ângulo de fase) mostrados na Figura 31a, apresentam ângulos de fase ao redor de $-80^{\circ}$ nas regiões de baixa freqüência para todos os períodos de imersão, sendo que houve um pequeno aumento destes valores no decorrer do ensaio. Não houve variação significativa no formato dos diagramas de Bode, tendo sido observada a formação de um ombro em freqüências da ordem de $100 \mathrm{~Hz}$ seguido por um patamar até as baixas freqüências, provavelmente devido à sobreposição das constantes de tempo.

Com relação aos diagramas de Bode (módulo de Z) da Figura 31b, a impedância do aço PM2000 não variou ao longo do período de imersão avaliado, confirmando a estabilidade da camada passiva. Os valores do módulo de impedância foram próximos a $10^{6} \Omega . \mathrm{cm}^{2}$ a $0,01 \mathrm{~Hz}$.

Os diagramas de Nyquist (Figura 31c) apresentam resultados altamente capacitivos e aumento da impedância entre 2 e 21 dias de ensaio, provavelmente associado a aumento nas propriedades de proteção do filme passivo. 

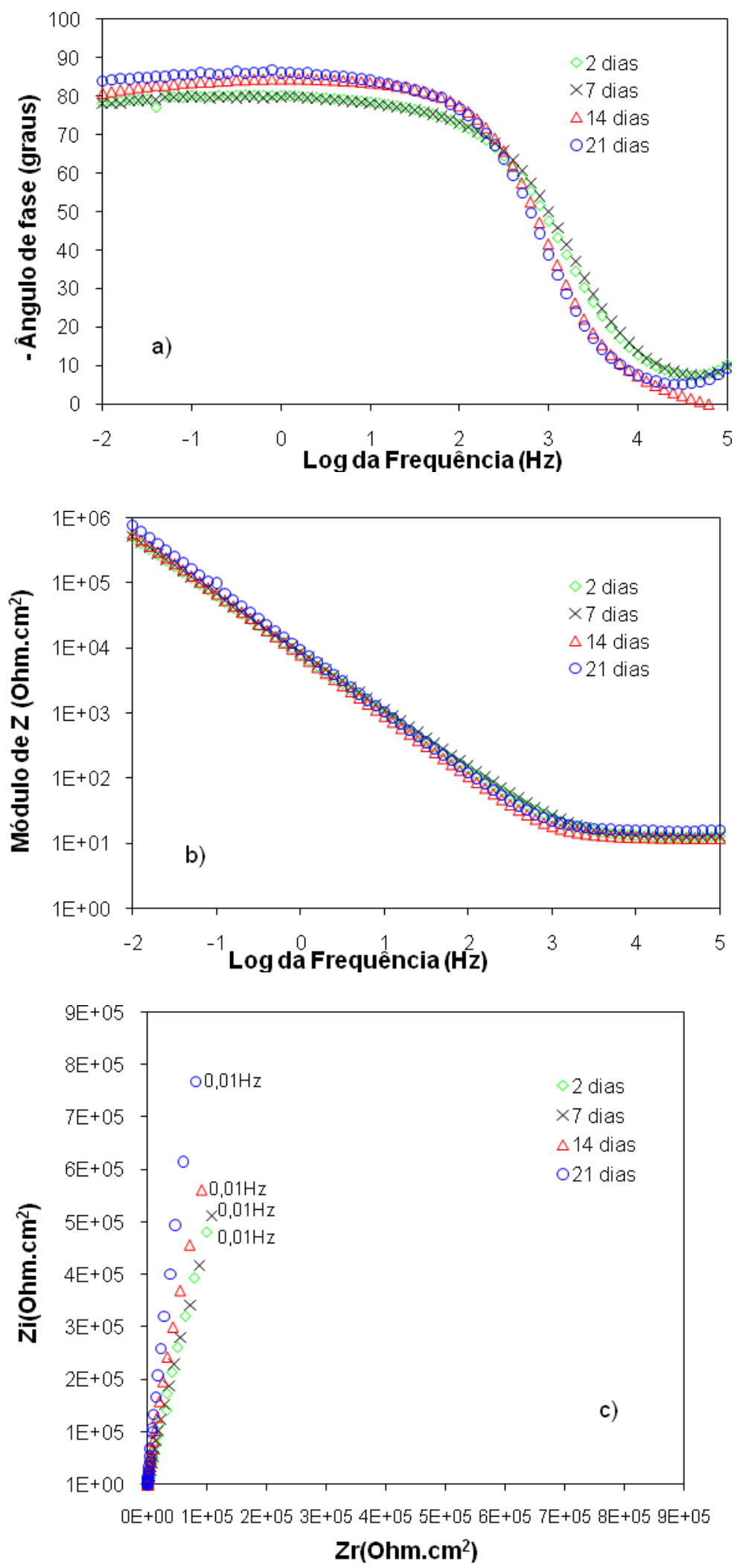

Figura 31 - Diagramas de impedância do aço PM2000 em solução PBS naturalmente aerada à 25ํㅡ: (a) Bode (Ângulo de fase); (b) Bode (Módulo de Z); (c) Nyquist. 


\subsubsection{Aço $316 L$}

Na Figura 32 são mostrados os diagramas de impedância do aço 316L após 2, 714 e 21 dias de imersão em solução PBS naturalmente aerada e a $25^{\circ} \mathrm{C}$.
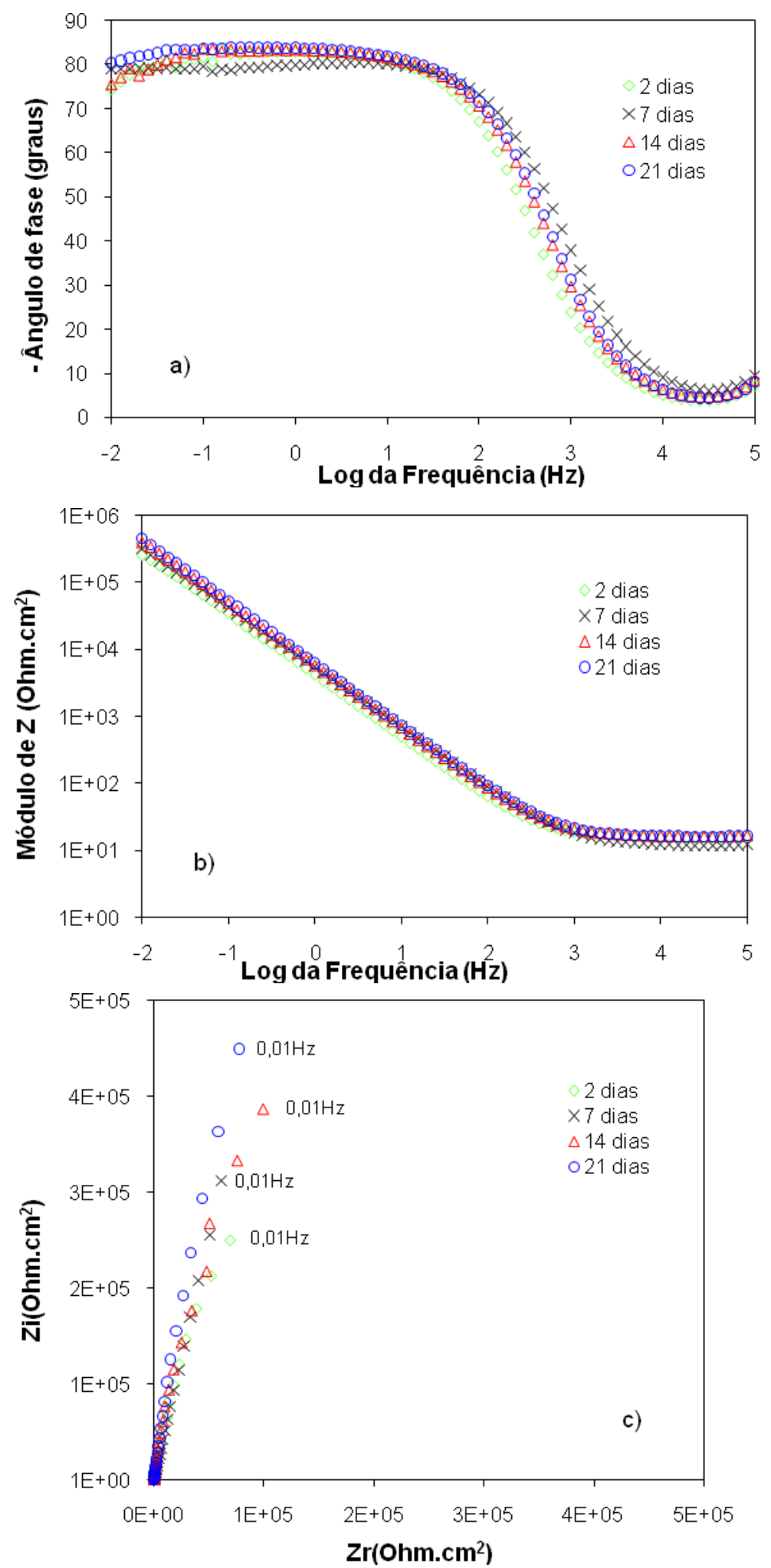

Figura 32 - Diagramas de impedância do aço 316L em solução PBS naturalmente aerada e a 25ํㅡ: (a) Bode (Ângulo de fase); (b) Bode (Módulo de Z); (c) Nyquist. 
Os diagramas de Bode (ângulo de fase) mostrados na Figura 32a, revelam que não houve mudança significativa nos diagramas em função do tempo de imersão. Todos os diagramas apresentaram a formação de um ombro entre $100 \mathrm{~Hz}$ e $10 \mathrm{~Hz}$ seguido por um patamar até baixas freqüências.

Nos diagramas da Figura 32b, os períodos de imersão de 2, 7, 14 e 21 dias não apresentaram um desvio do comportamento capacitivo. Houve uma aproximação dos valores do módulo das impedâncias para todas as freqüências estudadas. Na região de $0,01 \mathrm{~Hz}$ todas as amostras apresentaram valores com ordem de grandeza de $10^{5} \Omega . \mathrm{cm}^{2}$.

Os diagramas de Nyquist da Figura 32c sugerem o início de um arco altamente capacitivo que não se completa na região de baixas freqüências para todos os períodos de imersão. Nota-se também o aumento da impedância nas baixas freqüências com o tempo de imersão até 21 dias de ensaio.

\subsubsection{Aço 17-4PH PIM}

Na Figura 33 são mostrados os diagramas de impedância do aço 174PH PIM após 2, 714 e 21 dias de imersão, em solução PBS naturalmente aerada à $25^{\circ} \mathrm{C}$.

Os diagramas de Bode (ângulo de fase), mostrados na Figura 33a, revelam um comportamento capacitivo em todos os períodos de imersão com a formação de um ombro na região de $100 \mathrm{~Hz}$. Na região entre $100 \mathrm{~Hz}$ e 0,01Hz ocorreu a formação de um patamar. Para o período de imersão de 2 dias ocorreu uma queda do ângulo de fase em baixa freqüência atingindo o valor de aproximadamente $-70^{\circ}$ em $0,01 \mathrm{~Hz}$. Nesta mesma freqüência, as demais amostras obtiveram valores de ângulo de fase ao redor de $-80^{\circ}$. O módulo de impedância em função da freqüência (Figura 33b) apresentou similaridade para todos aos tempos de imersão, atingindo valores de $10^{5} \Omega . \mathrm{cm}^{2}$ a $0,01 \mathrm{~Hz}$. 

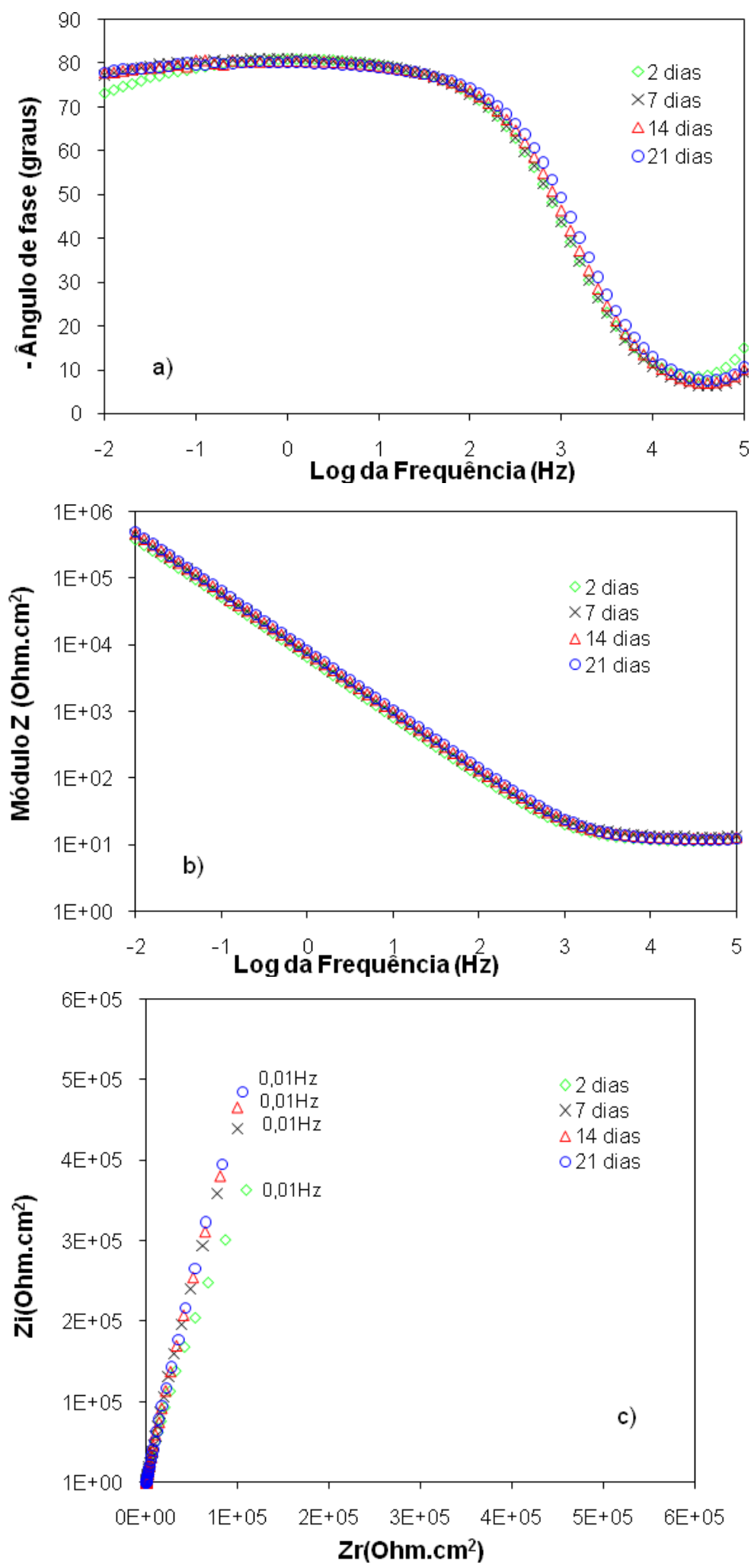

Figura 33 - Diagramas de impedância do aço 17-4PH PIM em solução PBS Diagramas de impedância do aço 17-4PH PIM em solução PBS naturalmente aerada à 25으: (a) Bode (Ângulo de fase); (b) Bode (Módulo de Z); (c) Nyquist. 
Nos diagramas de Nyquist (Figura 33c) fica caracterizado o início de arco altamente capacitivo para todos os períodos de imersão. Para 7, 14 e 21 dias não houve alteração significativa dos resultados de impedância, demonstrando a estabilidade do sistema.

\subsubsection{Comparação entre os quatro aços avaliados}

Para melhor visualização dos resultados de EIE foram feitos gráficos comparativos dos diagramas obtidos. A Figura 34 mostra os diagramas de Bode (ângulo de fase) para os aços 316L, 1802, 17-4PH PIM e PM2000 nos períodos de imersão de 2 e 21 dias em solução PBS a 25ํㅡ.
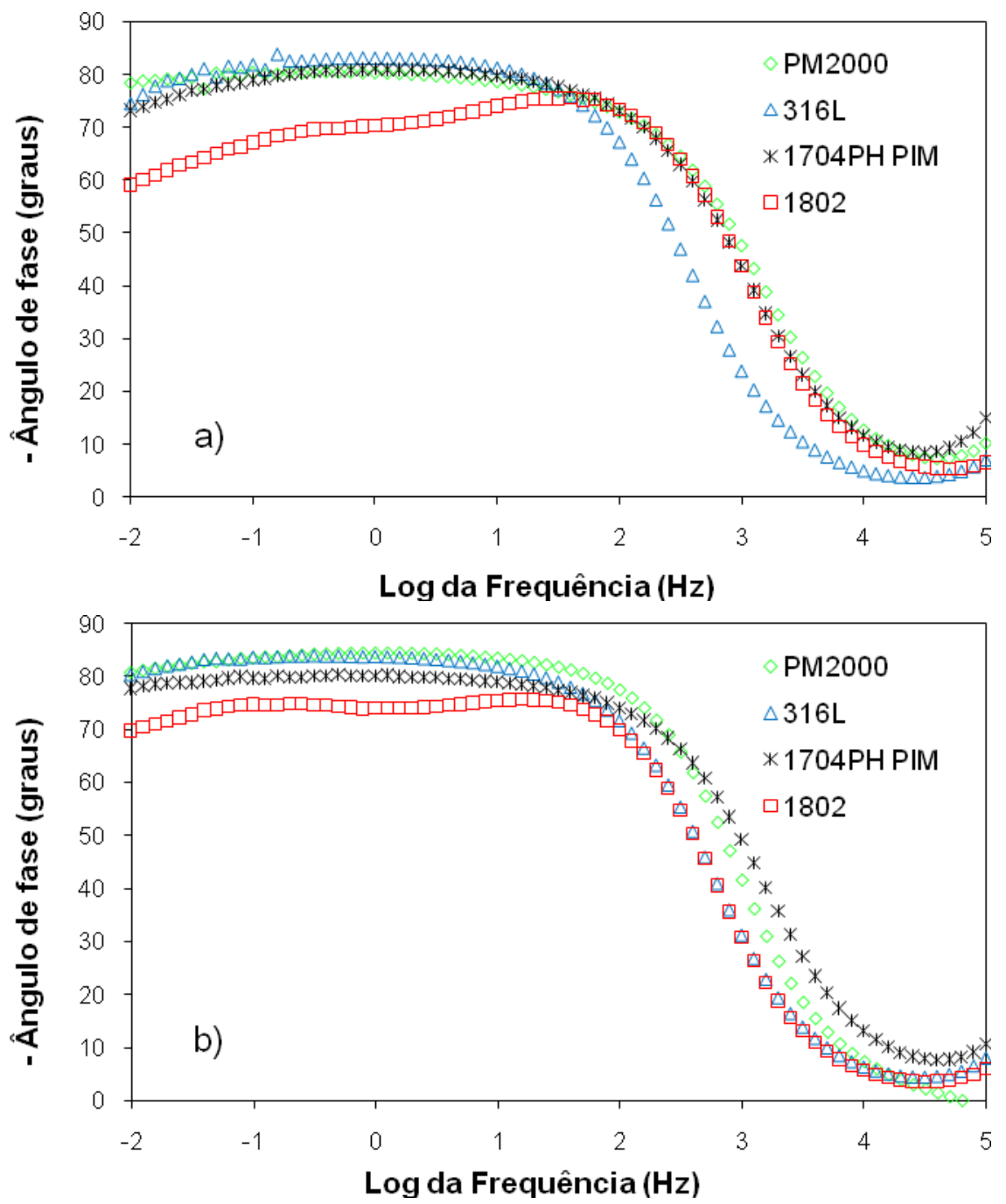

Figura 34 - Diagramas de Bode (ângulo de fase) dos aços PM2000, 316L, 1802 e 17-4PH PIM em solução PBS naturalmente aerada à 25 C: (a) 2 dias de imersão; (b) 21 dias de imersão.

Para as amostras dos aços PM2000, 17-4PH PIM e 1802 com dois dias de imersão (Figura 34a), houve uma proximidade dos ângulos de fase no intervalo 
entre $100 \mathrm{kHz}$ e $100 \mathrm{~Hz}$. No diagrama referente à amostra de 316L, a constante de tempo que aparece em médias freqüências, está deslocada para freqüências mais baixas. Além disso, esta apresenta caráter menos capacitivo. Para freqüências inferiores a $100 \mathrm{~Hz}$ o aço 1802 apresentou uma queda significativa nos valores do ângulo de fase, atingindo o menor valor de $-60^{\circ}$ a $0,01 \mathrm{~Hz}$. Para as ligas 316L, PM2000 e 17-4PH PIM ocorreu a formação de um patamar com ângulo próximo de $-80^{\circ}$ nas freqüências entre $100 \mathrm{~Hz}$ e $0,01 \mathrm{~Hz}$. Nesta última freqüência o aço PM2000 apresentou valores de ângulo de fase ligeiramente superiores aos do $316 \mathrm{~L}$ e do 17-4PH PIM, porém muito superiores aos do aço 1802.

Em 21 dias de imersão, os diagramas (Figura 34b) revelaram que houve um aumento dos valores de ângulo de fase na região de médias e baixas freqüências para todas as amostras, demonstrando que a camada superficial de óxidos tornou-se mais protetora no decorrer do experimento. Todos os diagramas mostram a formação de um ombro próximo a $100 \mathrm{~Hz}$. Os menores ângulos de fase para freqüências inferiores a $100 \mathrm{~Hz}$ foram associados ao aço 1802. Os maiores ângulos de fase relacionados com a liga PM2000 indicam comportamento altamente capacitivo e estes resultados associados às altas impedâncias, como já indicado nos diagramas de Nyquist para a liga PM2000 (Figura 31b), mostram a elevada resistência à corrosão do PM2000 com valores do módulo de impedância próximos a $10^{6} \Omega . \mathrm{cm}^{2}$ a $0,01 \mathrm{~Hz}$. Os maiores valores de módulo de impedância em comparação com os dos demais aços indicam a presença de um filme de óxido passivo menos defeituoso.

Os diagramas comparativos de Nyquist dos aços PM2000, 316L, 1802 e 17-4PH PIM, para 2 e 21 dias de imersão em solução PBS, naturalmente aerada à 25ํㅡ, são mostrados na Figura 35. 


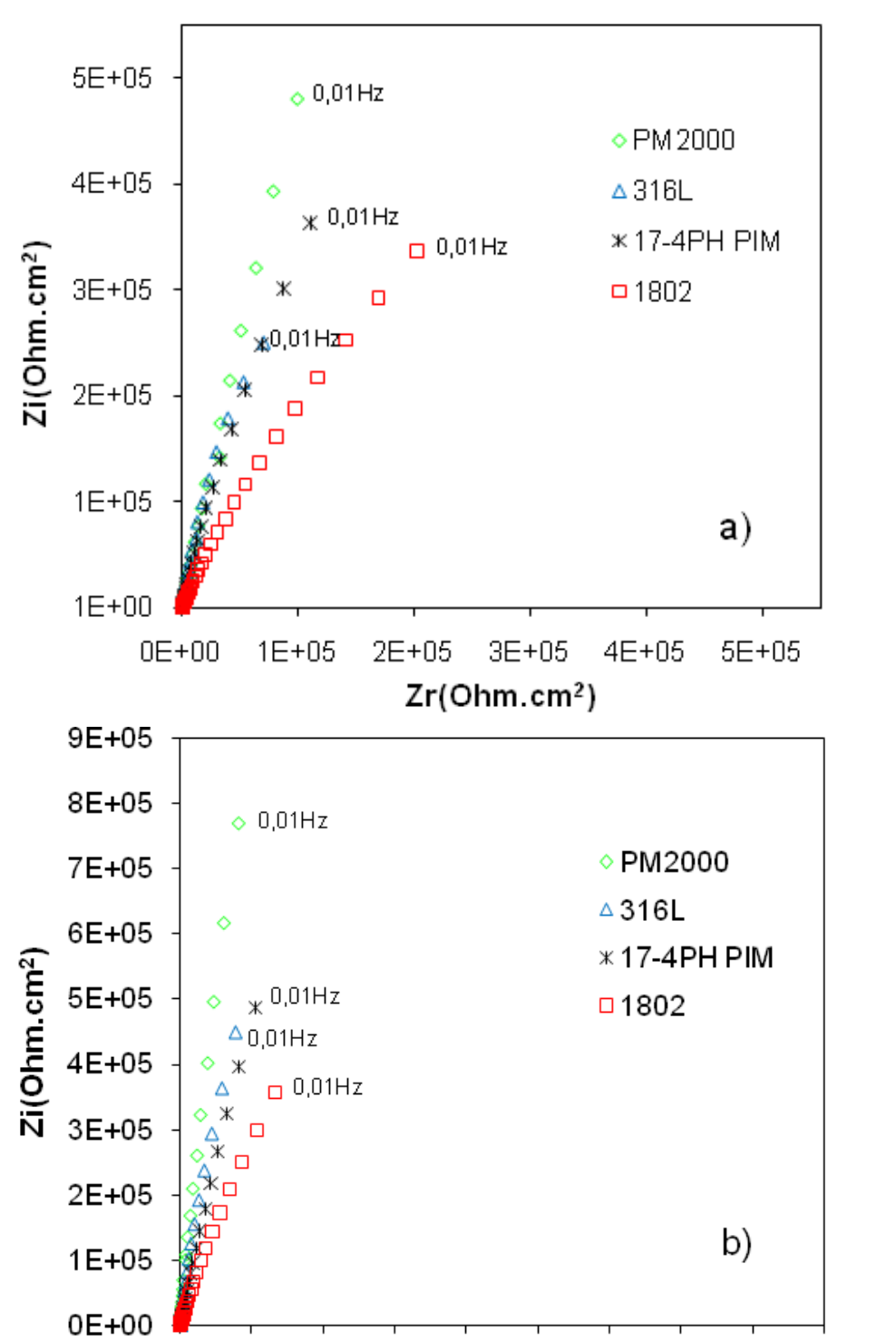

$0 E+0 \quad 1 E+5 \quad 2 E+5 \quad 3 E+5 \quad 4 E+5 \quad 5 E+5 \quad 6 E+5 \quad 7 E+5 \quad 8 E+5 \quad 9 E+5$

$\mathrm{Zr}\left(\mathrm{Ohm} . \mathrm{cm}^{2}\right)$

Figura 35 - Diagramas de Nyquist dos aços PM2000, 316L, 1802 e 17-4PH PIM em solução PBS naturalmente aerada à 25을 (a) 2 dias de imersão; (b) 21 dias de imersão.

Pode-se observar que para dois dias de imersão (Figura 35a) o PM2000 apresentou maiores impedâncias, seguido pelo 316 e 17-4PH PIM e, por último, pelo aço 1802. Com o decorrer do experimento e até 21 dias (Figura 35b), esta ordem não se alterou, porém os resultados apresentaram ligeiro aumento de impedância com o tempo de imersão para todas as amostras, e isto sugere que, com o tempo de imersão a camada torna-se gradativamente mais protetora. Este resultado pode ocorrer em conseqüência do espessamento do óxido ou pela diminuição na densidade de defeitos no óxido. 


\subsubsection{Circuitos Elétricos Equivalentes (CEE)}

Para analisar os resultados de EIE, foram testados alguns circuitos para cada material, baseados em um número limitado de componentes elétricos.

Os circuitos propostos para ajustar os resultados de EIE são apresentados na Figura 36.
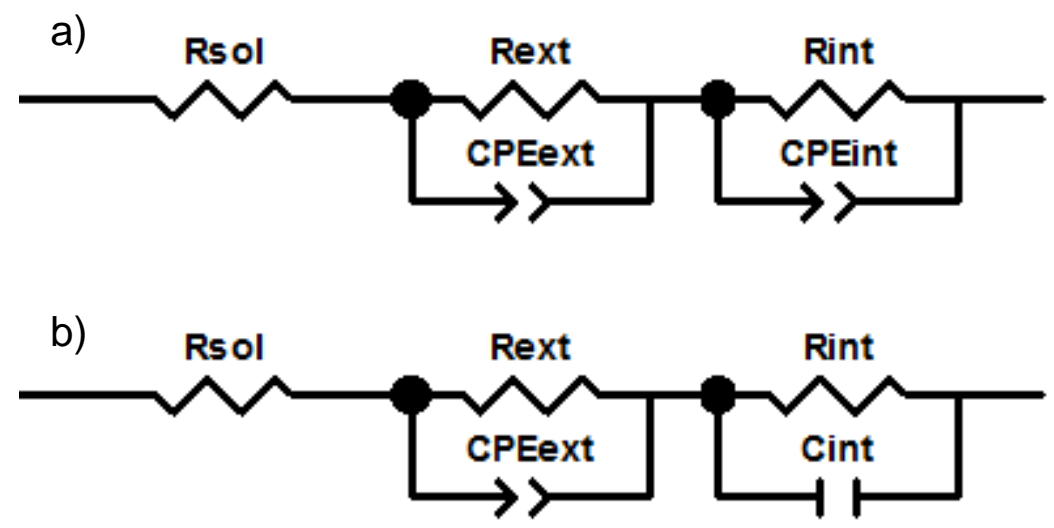

Figura 36 - Circuitos elétricos equivalentes propostos para caracterizar a camada passiva das ligas investigadas neste estudo.

Para o aço 1802, o modelo proposto na Figura 36a foi o que obteve o melhor ajuste. Apesar de um elemento CPE representar a não idealidade do sistema eletroquímico, quanto se efetuaram os ajustes para os aços 17-4PH PIM, PM2000 e 316L com dois elementos R-CPE em série, os valores de $n_{\text {int }}$ ficaram muito próximos de 1. Isto significa que o filme interno (rico em óxido de cromo) para estes três aços teve comportamento próximo ao de um capacitor ideal. Por este motivo foi proposto o CEE da Figura 36b.

$\mathrm{Na}$ Figura 37, observa-se a representação do modelo físico adotado para explicar o comportamento eletroquímico com relação ao filme passivo formado sobre os aços inoxidáveis.

Há consenso na literatura sobre a formação de um filme passivo dúplex sobre os aços inoxidáveis. (DA CUNHA BELO et al. 1998, MONTEMOR et al. 2000, HAKIKI et al. 1995, ANTUNES 2006, TERADA 2008). A camada mais externa, em contato com o eletrólito, é mais porosa e composta principalmente por óxidos de ferro. A camada mais interna, em contato com o substrato, é mais compacta e composta principalmente por óxido de cromo, sendo mais protetora contra a corrosão que a primeira. 


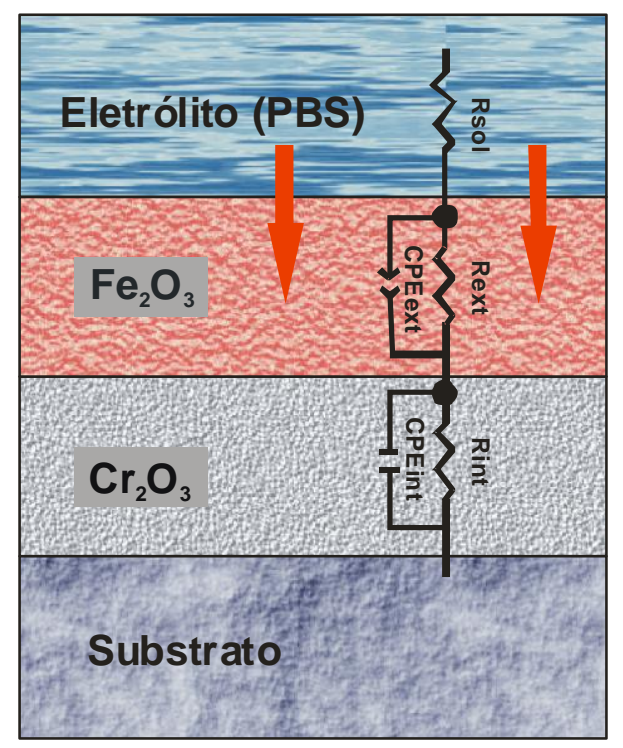

Figura 37 - Representação dos modelos físicos adotados para explicar o comportamento eletroquímico dos aços ensaiados.

$\mathrm{Na}$ Figura 37, observa-se a representação de uma amostra de aço inoxidável imerso em um eletrólito. A resistência do meio PBS é descrita pelo elemento $R_{\text {sol. }}$ Em série com este elemento, temos dois R-CPE que representam o filme passivo dúplex, formado sobre os aços inoxidáveis. Segundo GE et al. (2003), as variações dos elementos R e CPE indicam alterações no grau de compactação da camada passiva do aço inoxidável com o tempo de imersão. Desta forma, o aumento da resistência $(R)$ e diminuição da capacitância (CPE) sugerem um filme passivo menos defeituoso. O primeiro R-CPE é utilizado para descrever os processos eletroquímicos na interface eletrólito/filme passivo, sendo $R_{\text {ext }}$ a resistência da camada externa (rica em óxido de ferro) e $C P E_{\text {ext }}$ a sua capacitância. No segundo $\mathrm{R}-\mathrm{CPE}, \mathrm{R}_{\text {int }}$ representa a resistência da camada interna (rica em óxido de cromo) e $\mathrm{CPE}_{\text {int }}$ a sua capacitância. Para o CEE proposto na Figura 36a o modelo físico é o mesmo, sendo apenas substituído o segundo elemento $\mathrm{CPE}_{\mathrm{int}}$ por um capacitor ideal $\left(\mathrm{C}_{\mathrm{int}}\right)$.

Os valores dos componentes dos CEE, obtidos pelos ajustes dos resultados experimentais de 2 dias de imersão, são mostrados na Tabela 9. Os valores ajustados para 21 dias de imersão estão descritos na Tabela 10. Os erros correspondentes a cada componente do CCE são mostrados no ANEXO. 
Tabela 9 - Valores ajustados dos diagramas de impedância pelos CEE, após 2 dias de imersão em meio PBS, naturalmente aerado à 25으.

\begin{tabular}{|c|c|c|c|c|}
\hline Liga & 1802 & 17-4PH PIM & PM2000 & $316 \mathrm{~L}$ \\
\hline $\begin{array}{c}\mathrm{R}_{\mathrm{sol}} \\
\left(\Omega . \mathrm{cm}^{2}\right)\end{array}$ & 29,8 & 11,55 & 12,5 & 16,15 \\
\hline $\begin{array}{c}\mathrm{CPE}_{\mathrm{ext}} \\
\left(\mathrm{cm}^{-2} \mathrm{~s}^{-n} \Omega\right)\end{array}$ & $4,26 \times 10^{-5}$ & $8,3 \times 10^{-5}$ & $7,07 \times 10^{-5}$ & $1,46 \times 10^{-4}$ \\
\hline $\mathrm{n}_{\mathrm{ext}}$ & 0,85 & 0,80 & 0,78 & 0,81 \\
\hline $\begin{array}{c}\mathrm{R}_{\mathrm{ext}} \\
\left(\Omega . \mathrm{cm}^{2}\right)\end{array}$ & $1,0 \times 10^{4}$ & $3,6 \times 10^{4}$ & $4,3 \cdot 10^{4}$ & $2,45 \times 10^{4}$ \\
\hline $\begin{array}{c}\mathrm{C}_{\text {int }} \\
\left(\mathrm{F} . \mathrm{cm}^{2}\right)\end{array}$ & - & $3,99 \times 10^{-5}$ & $3,2.10^{-5}$ & $5,67 \times 10^{-5}$ \\
\hline $\begin{array}{c}\mathrm{CPE}_{\mathrm{int}} \\
\left(\mathrm{cm}^{-2} \mathrm{~s}^{-\mathrm{n}} \Omega\right)\end{array}$ & $2,14 \times 10^{-5}$ & - & - & - \\
\hline $\mathrm{n}_{\text {int }}$ & 0,85 & - & - & - \\
\hline $\begin{array}{c}\mathrm{R}_{\mathrm{int}} \\
\left(\Omega . \mathrm{cm}^{2}\right)\end{array}$ & $1,06 \times 10^{6}$ & $1,5 \times 10^{6}$ & $3,17 \times 10^{6}$ & $1,36 \times 10^{6}$ \\
\hline
\end{tabular}

Tabela 10 - Valores ajustados dos diagramas de impedância pelos CEE, após 21 dias de imersão em meio PBS, naturalmente aerado à $25^{\circ} \mathrm{C}$.

\begin{tabular}{|c|c|c|c|c|}
\hline Liga & 1802 & 17-4PH PIM & PM2000 & 316L \\
\hline $\begin{array}{c}\mathrm{R}_{\mathrm{sol}} \\
\left(\Omega . \mathrm{cm}^{2}\right)\end{array}$ & 30,9 & 11,78 & 15,28 & 16,2 \\
\hline $\begin{array}{c}\mathrm{CPE}_{\mathrm{ext}} \\
\left(\mathrm{cm}^{-2} \mathrm{~s}^{-n} \Omega\right)\end{array}$ & $9,01 \times 10^{-5}$ & $6,6 \times 10^{-5}$ & $7,99 \times 10^{-5}$ & $1,28 \times 10^{-4}$ \\
\hline $\mathrm{n}_{\mathrm{ext}}$ & 0,80 & 0,79 & 0,75 & 0,80 \\
\hline $\begin{array}{c}\mathrm{R}_{\mathrm{ext}} \\
\left(\Omega . \mathrm{cm}^{2}\right)\end{array}$ & $5,6 \times 10^{3}$ & $3,57 \times 10^{4}$ & $1,8 \times 10^{4}$ & $2,53 \times 10^{4}$ \\
\hline $\begin{array}{c}\mathrm{C}_{\text {int }} \\
\left(\mathrm{F} . \mathrm{cm}^{2}\right)\end{array}$ & - & $3,07 \times 10^{-5}$ & $2,60 \cdot 10^{-5}$ & $3,46 \times 10^{-5}$ \\
\hline $\begin{array}{c}\mathrm{CPE}_{\mathrm{int}} \\
\left(\mathrm{cm}^{-2} \mathrm{~s}^{-n} \Omega\right)\end{array}$ & $2,82 \times 10^{-5}$ & - & - & - \\
\hline $\mathrm{n}_{\text {int }}$ & 0,90 & - & - & - \\
\hline $\begin{array}{c}\mathrm{R}_{\mathrm{int}} \\
\left(\Omega . \mathrm{cm}^{2}\right)\end{array}$ & $1,63 \times 10^{6}$ & $2,93 \times 10^{6}$ & $5,13 \times 10^{6}$ & $3,42 \times 10^{6}$ \\
\hline
\end{tabular}

Conforme os valores das Tabela 9 e Tabela 10, observa-se que para o aço 1802 o valor da $R_{\text {ext }}$ diminuiu com o tempo de imersão. Esta redução pode estar relacionada à penetração de eletrólito pela camada mais externa. Tal variação, associada ao aumento dos valores de capacitância $\mathrm{CPE}_{\text {ext }}$, sugere que esta camada tornou-se mais defeituosa. Apoiando esta hipótese, tem-se o valor 
de $n_{\text {ext }}$ que passou de 0,85 para 0,80, após 21 dias de imersão. Com o decorrer do ensaio, a camada interna do filme passivo, aparentemente tornou-se mais resistente (aumento nos valores da $\mathrm{R}_{\text {int }}$ ) provavelmente associado à diminuição na densidade de defeitos (aumento de $\mathrm{n}_{\text {int }}$ ).

Para o aço 17-4PH PIM, os valores de $R_{\text {ext }}$ mantiveram-se praticamente constantes com o decorrer do ensaio. Como ocorreu uma

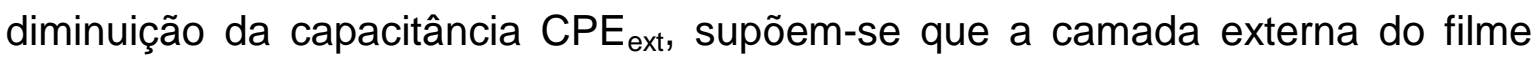
passivo tornou-se menos compacta e mais defeituosa. Na região de baixas freqüências, o comportamento eletroquímico é dominado pela resposta da camada interna de óxido de cromo (parâmetros $\mathrm{R}_{\text {int }}$ e $\mathrm{C}_{\text {int }}$ ). A resistência desta camada praticamente dobrou em 21 dias, atingindo um valor de 2,93 x $10^{6} \Omega . \mathrm{cm}^{2}$. Associado a uma redução da capacitância, sugere-se que esta camada tornou-se mais espessa ou menos defeituosa, oferecendo maior resistência à transferência de cargas com o aumento do tempo de imersão.

Para o aço PM2000, o valor do elemento resistivo $R_{\text {ext }}$ diminuiu ao longo do tempo de imersão, o que pode ser causado por uma elevação na condutividade da camada externa do filme passivo. Este efeito pode resultar da penetração de íons do eletrólito na camada de óxido. A elevação nos valores da capacitância $\mathrm{CPE}_{\text {ext }}$ sugere redução na espessura desta camada. Mesmo ocorrendo uma possível penetração de espécies agressivas do eletrólito através da camada externa de óxido de ferro, houve um aumento na resistividade interna $\left(R_{\text {int }}\right)$, após 21 dias de imersão. Estes resultados indicam que ocorreu uma melhora nas propriedades protetoras da camada passiva interna e que esta é a principal responsável pela resistência do material contra corrosão.

Os valores ajustados pelos CEE, para o aço $316 \mathrm{~L}$, mostraram que os parâmetros dos elementos $R_{\text {ext, }} n_{\text {ext }}$ e $C P E_{\text {ext }}$ mantiveram-se praticamente inalterados no decorrer do experimento. Isto indica que a camada externa de óxido de ferro é bastante estável ao longo do período de imersão. Os elementos $\mathrm{R}_{\text {int }}$ e $\mathrm{C}_{\text {int }}$ tiveram seus valores de resistência aumentados e de capacitância reduzidos, respectivamente. Estes dados descrevem uma camada mais protetora após 21 dias de imersão. 
5.5.6.1 Comparativo dos valores obtidos do ajuste dos resultados experimentais ao CEE proposto para 2 dias de imersão

Com relação à camada externa, os aços PM2000, 17-4PH PIM e 1802 apresentaram valores $R_{\text {ext }}$ da mesma ordem de grandeza $\left(10^{4} \Omega . \mathrm{cm}^{2}\right)$, sendo que a $R_{\text {ext }}$ do 1802 foi a única inferior à do aço 316L. A capacitância do elemento $\mathrm{CPE}_{\text {ext }}$ diminuiu na seguinte seqüência: $316 \mathrm{~L}>17-4 \mathrm{PH} \mathrm{PIM}>\mathrm{PM} 2000>1802$. Os valores de impedância indicaram que a camada mais interna do filme passivo de aços inoxidáveis é a principal responsável pela resistência à corrosão destes materiais. Todos os aços deste trabalho apresentaram valores de $R_{\text {int }}$ elevados (da ordem de $10^{6} \Omega . \mathrm{cm}^{2}$ ), ou seja, duas ordens de grandeza superiores que a resistividade de suas respectivas camadas externas. O aço PM2000 apresentou os valores mais elevados de $R_{\text {int }}$, sendo duas vezes superiores ao do aço $316 \mathrm{~L}$. Por outro lado, o aço 1802 foi o único que obteve valores de resistência interna inferior aos do 316L. Por estes dados pode-se verificar que a camada passiva interna do PM2000, rica em óxido de cromo, apresenta a melhor resistência à corrosão, dificultando o acesso das espécies agressivas presentes no eletrólito ao substrato e consequentemente, a corrosão deste.

5.5.6.2 Comparativo dos valores obtidos do ajuste dos resultados experimentais ao CEE proposto para 21 dias de imersão

Os resultados para 21 de imersão mostraram uma redução na $R_{\text {ext }}$ dos

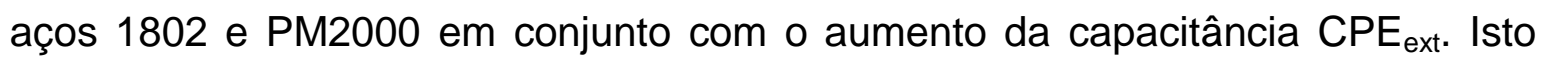
ocorre em função do aumento na quantidade de defeitos na camada externa de óxido de ferro, devido ao contato com as espécies agressivas do eletrólito. Para os aços 17-4PH PIM e 316L a resistência externa manteve-se praticamente igual. Associada a uma pequena redução na capacitância, pode-se supor que as camadas externas destes dois aços ficaram mais espessas, mantendo a mesma resistividade.

Com relação à camada interna do filme passivo, o PM2000 obteve os valores mais elevados de $R_{\text {int }}$ entre todas as amostras. Por outro lado, o aço 1802 foi o que apresentou a resistividade interna mais baixa. Mesmo assim, todos os aços apresentaram valores de $R_{\text {int }}$ da ordem de $10^{6} \Omega . \mathrm{cm}^{2}$, indicando elevada proteção contra corrosão destes aços em meio PBS. A Figura 38 mostra os 
valores de $R_{\text {int }}$ dos aços 1802, 17-4PH PIM, PM2000 e 316L, para 2 e 21 dias de imersão em PBS.

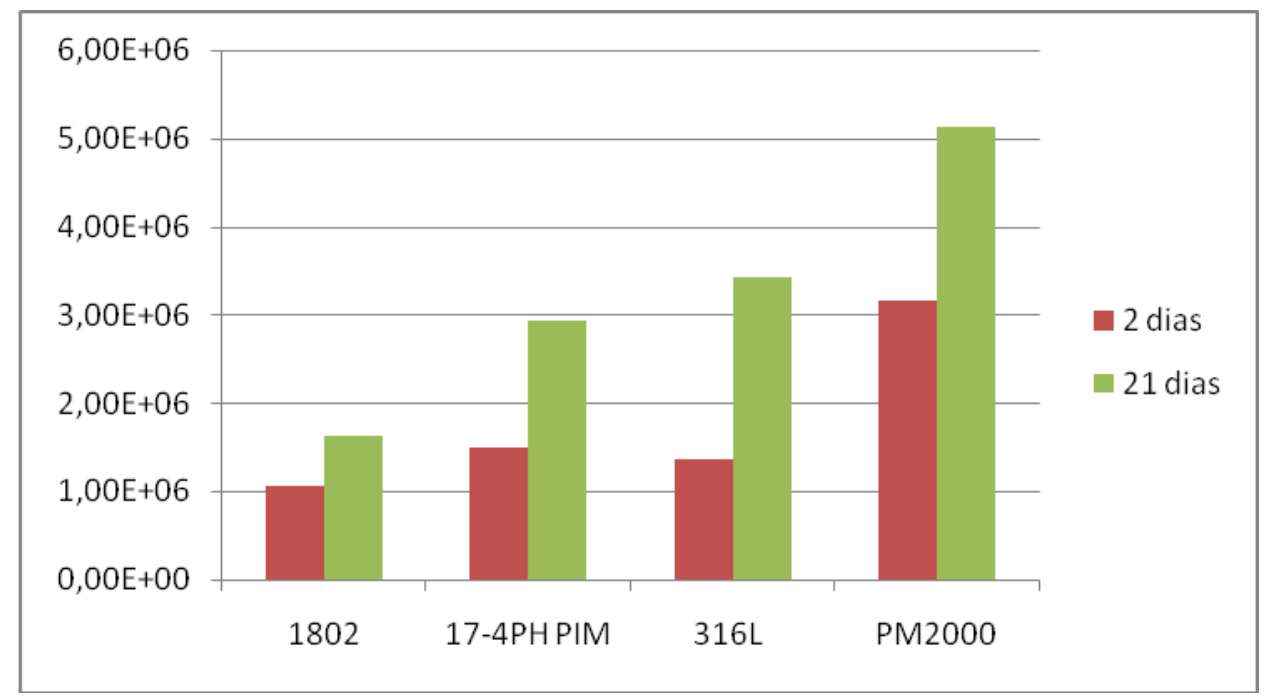

Figura 38 - Valores da resistência da camada interna do filme passivo, das ligas ensaiadas, obtidos pelos ajustes dos resultados experimentais ao CEE da Figura 36.

Em todos os aços estudados a $R_{\text {int }}$ foi cerca de duas ordens de grandeza superior aos valores de resistência da camada externa. Isto confirma que a resistência à corrosão destes materiais é conferida pela camada interna rica em óxido de cromo. Segundo a Figura 38, observa-se que os valores de $R_{\text {int }}$ aumentaram no decorrer do período de imersão para todas as amostras. $A R_{\text {int }}$ da liga PM2000 foi superior à das demais, tanto para 2 como 21 dias, sugerindo que o filme passivo deste material é mais protetor contra corrosão.

\subsection{Propriedades Eletrônicas do Filme Passivo - Gráficos de Mott-Schottky}

Após análise inicial dos resultados de EIE e das polarizações anódicas, decidiu-se investigar as características eletrônicas do filme passivo do aço PM2000. Para tanto, foi proposta a metodologia de Mott-Schottky comparando as propriedades eletrônicas do filme passivo do aço 316L com o filme passivo formado sobre o aço PM2000.

Esclarecendo a terminologia adotada, a parte de inclinação positiva da reta, contida entre os potenciais de $-0,4 \mathrm{~V}$ e $+0,25 \mathrm{~V}$, está associada a um semicondutor extrínseco tipo-n. Este semicondutor apresenta excesso de cargas negativas geradas pelas lacunas de íons metálicos das camadas externas de óxidos e hidróxidos de ferro e, portanto, são doadores de cargas. O número de 
dopantes será representado pela abreviação $N_{D}$ (número de doadores) toda vez que se referir a esta parte do gráfico de Mott-Schottky. Por outro lado, a parte de inclinação negativa da reta, contida entre os potenciais de $-0,4 \vee$ e $-1 \vee$, está associada a um semicondutor extrínseco tipo-p. Este semicondutor apresenta excesso de cargas positivas geradas pelas lacunas ou buracos eletrônicos das camadas externas de óxido de cromo e, portanto, são aceitadores de cargas. $\mathrm{O}$ número de dopantes será representado pela abreviação $\mathrm{N}_{\mathrm{A}}$ (número de aceitadores).

\subsubsection{Aço $316 L$}

Os gráficos de Mott-Schottky para o aço 316L após 2, 6, 12 horas e 2, 7, 14 e 21 dias de imersão, em solução PBS naturalmente aerada à $25^{\circ} \mathrm{C}$, são mostrados na Figura 39.

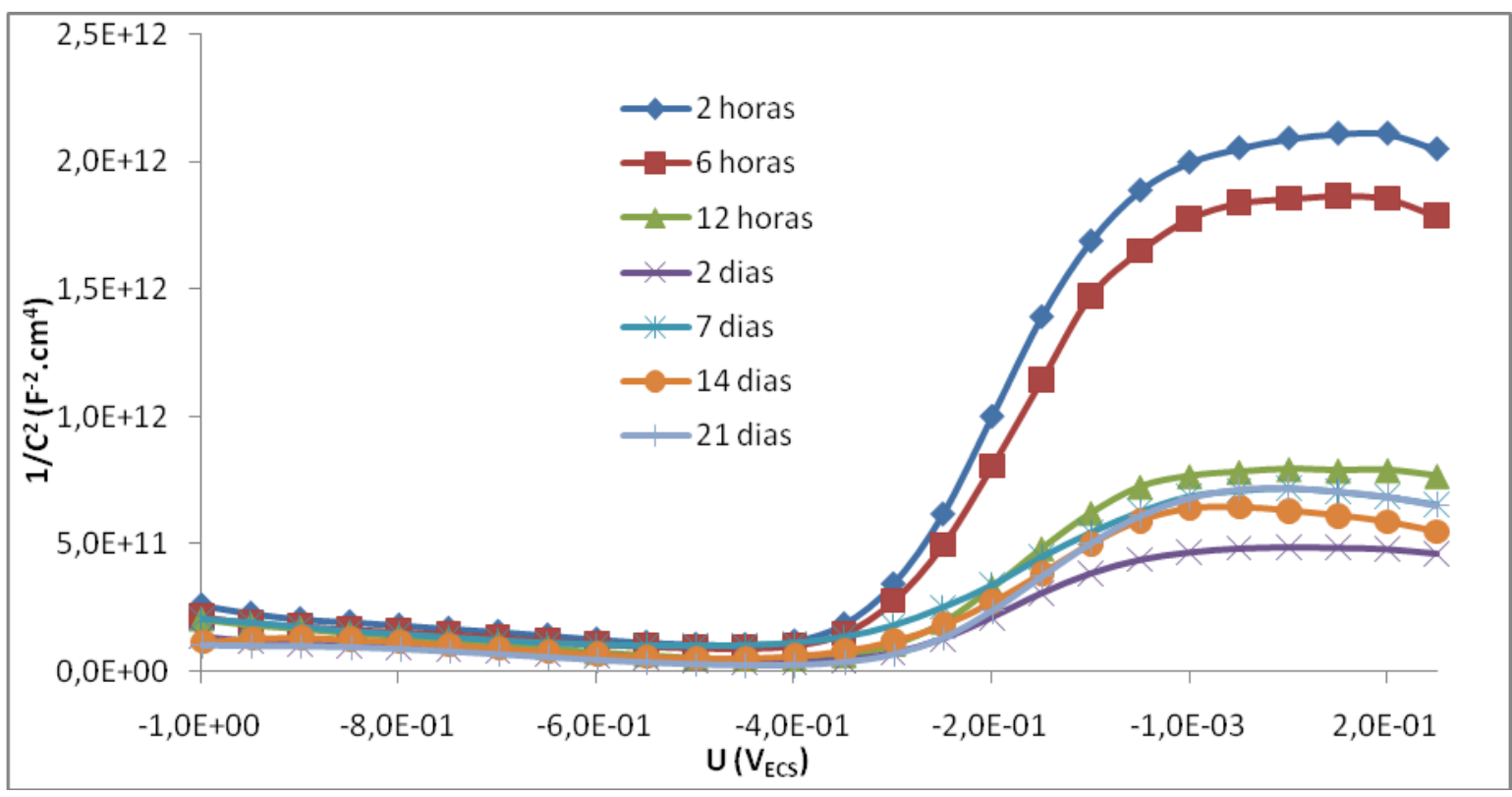

Figura 39 - Gráficos de Mott-Schottky para o aço 316L após diferentes períodos de imersão, em solução PBS naturalmente aerada à $25^{\circ} \mathrm{C}$.

Para os períodos de imersão de 2 e 6 horas, os gráficos mostraram uma inclinação significativamente mais elevada na região de potenciais entre -0,4 e $+0,25 \mathrm{~V}$, correspondente ao comportamento de um semicondutor tipo-n (inclinação positiva). Por estes valores de $1 / \mathrm{C}^{2}$ serem cerca de 4 vezes maiores, em comparação com os outros tempos de imersão, ocorreu um achatamento das demais curvas. Porém, este efeito é apenas visual, sendo que o comportamento 
de Mott-Schottky, exibido pela camada passiva do aço 316L, apresenta caráter dúplex em todos os períodos de imersão avaliados. Na Figura 40 são mostradas as curvas obtidas para tempos de ensaio entre 12 horas e 21 dias, para uma melhor definição dos dados obtidos neste período.

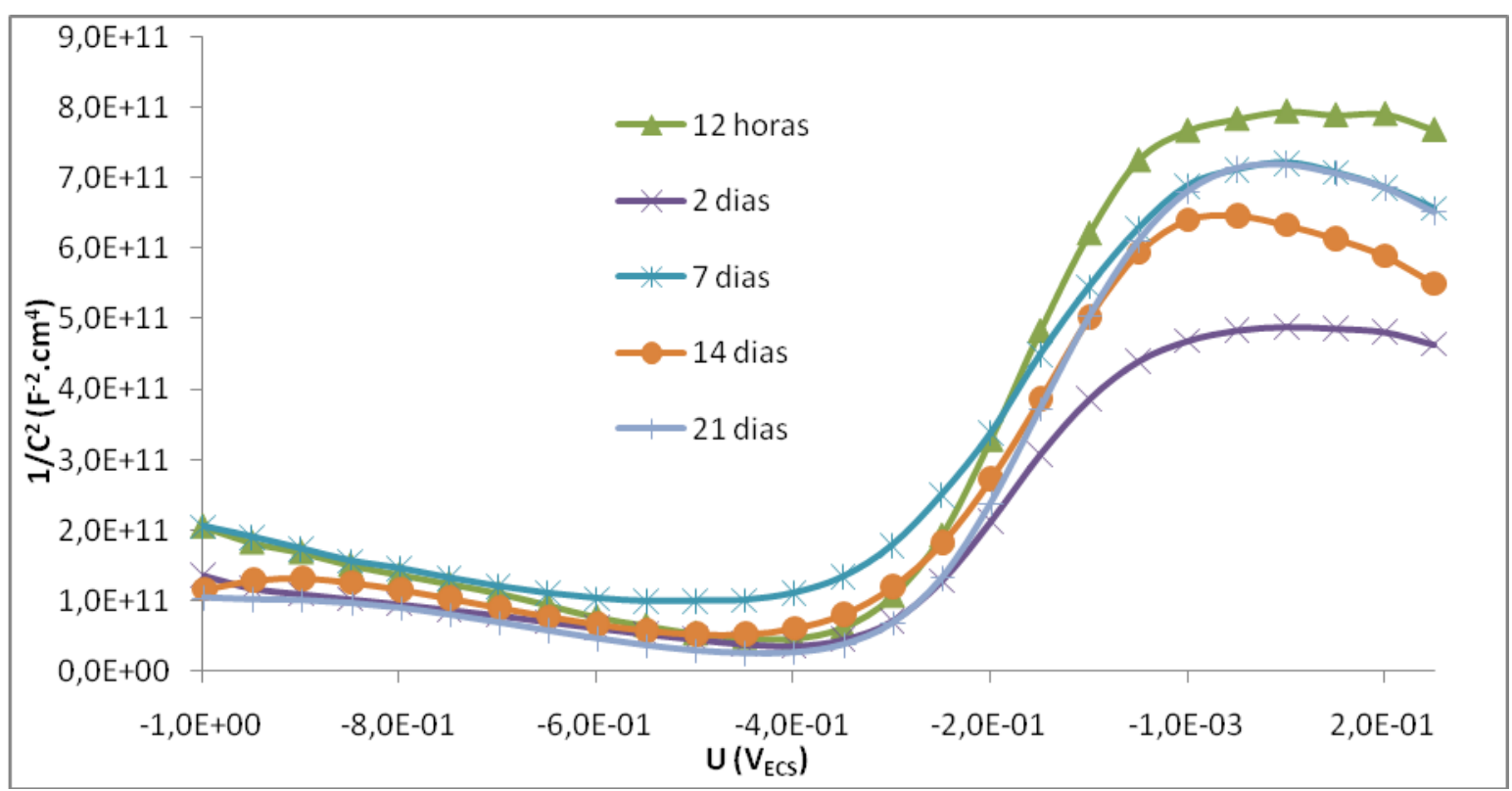

Figura 40 - Gráficos de Mott-Schottky para o aço 316L após 12 horas, 2, 7, 14 e 21 dias de imersão, em solução PBS naturalmente aerada à $25^{\circ} \mathrm{C}$.

Descrevendo-se a parte do gráfico correspondente aos doadores de cargas (inclinação positiva no potencial entre $-0,4$ e $+0,25 \mathrm{~V}$ ), observou-se que as amostras de 2 horas apresentaram a maior inclinação seguida por uma queda sucessiva até 2 dias. Após 7 dias houve um aumento da inclinação que se manteve muito próxima até o período final de 21 dias.

Para a região de inclinação negativa (potencial entre $-0,4 \vee$ e $-1 \mathrm{~V}$ ), responsável pela resposta dos semicondutores extrínsecos tipo-p, observa-se que não houve uma alteração tão significativa nas inclinações das retas quanto nas regiões de potencial entre $-0,4 \mathrm{~V}$ e $+0,25 \mathrm{~V}$. Estas pequenas alterações de inclinação serão mais bem visualizadas através do cálculo do número de dopantes para cada região e período de imersão, uma vez que, a inclinação da reta, obtida experimentalmente no gráfico corresponde aos termos $\frac{2}{\varepsilon \varepsilon_{0} e N_{q}}$ da equação de Mott-Schottky $\frac{1}{c^{2}}=\frac{2}{s s_{0} \otimes N_{q}}\left(-U+U_{f b}+\frac{k T}{B}\right)$ (Equação 2). 
Na Figura 41 pode-se visualizar o método de determinação do $\bigcup_{\mathrm{fb}}$ de uma amostra de aço 316L, após 12 horas de imersão. O potencial de banda plana $\left(\bigcup_{\mathrm{fb}}\right)$ ocorre para uma tensão de aproximadamente $-0,4 \mathrm{~V}$ em todos os períodos de imersão. Este valor está em acordo com os $\bigcup_{\mathrm{fb}}$ descritos por outros autores para aços inoxidáveis com camada passiva dúplex (HAKIKI et al.1995; DA CUNHA BELO et al. 1998; MONTEMOR et al. 2000, ANTUNES, 2000 e TERADA 2008).

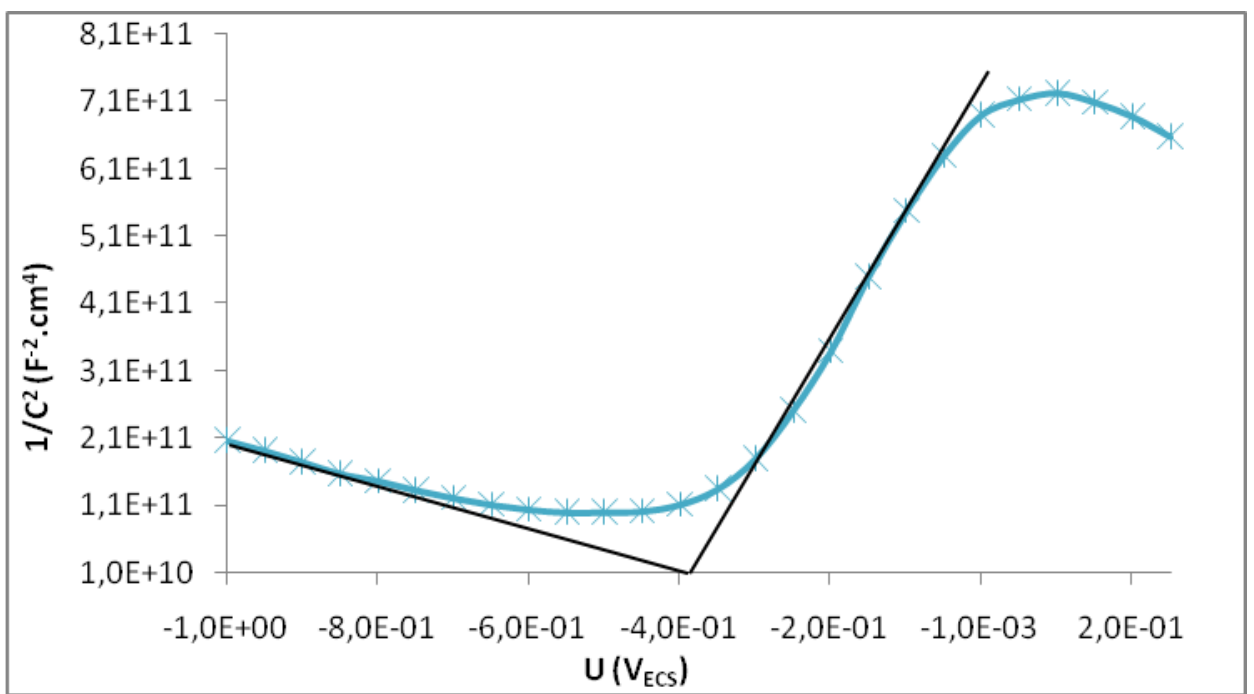

Figura 41 - Determinação do potencial de banda plana.

Os valores da concentração de doadores de carga no filme passivo $\left(\mathrm{N}_{\mathrm{D}}\right)$, determinados a partir dos gráficos de Mott-Schottky (Figura 39) na região de potenciais entre $-0,4$ e +0,25V (região de inclinação positiva), são mostrados na Figura 42.

Pelos valores obtidos, observa-se um aumento progressivo do número de doadores entre 2 horas e 2 dias de imersão. Após atingir um pico em 2 dias de imersão, ocorre diminuição gradual dos portadores de carga até o final do ensaio em 21 dias. Mesmo assim, o $N_{D}$ em 21 dias ainda é cerca de três vezes superior ao da amostra com duas horas de imersão. Isto significa que a camada mais externa do filme passivo, rica em óxido de ferro, apresenta características menos condutoras em 2 horas do que em 21 dias, sendo que, a condutividade máxima foi atingida após 2 dias. Os valores de grandeza da ordem de $10^{18}$ dopantes por $\mathrm{cm}^{3}$ revelam um filme com poucos defeitos intrínsecos. 


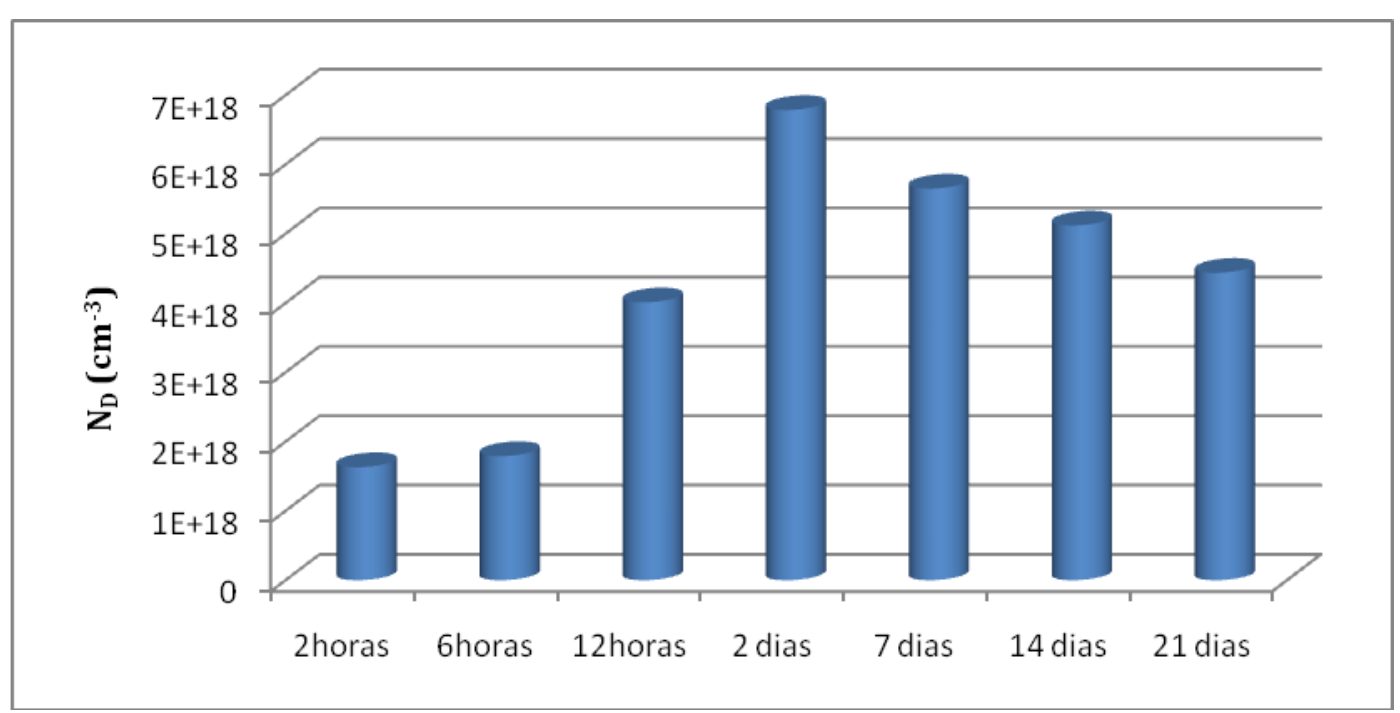

Figura 42 - Valores da concentração de doadores de carga no filme passivo do aço 316L, determinados a partir dos gráficos de Mott-Schottky da Figura 39, na região de potenciais entre $-0,4 \mathrm{~V}$ e $+0,25 \mathrm{~V}$.

A concentração de aceitadores de carga no filme passivo $\left(\mathrm{N}_{\mathrm{A}}\right)$, determinados a partir dos gráficos de Mott-Schottky (Figura 39) na região de potenciais entre $-1 \mathrm{~V}$ e $-0,4 \mathrm{~V}$ (região de inclinação negativa), são mostrados na Figura 43.

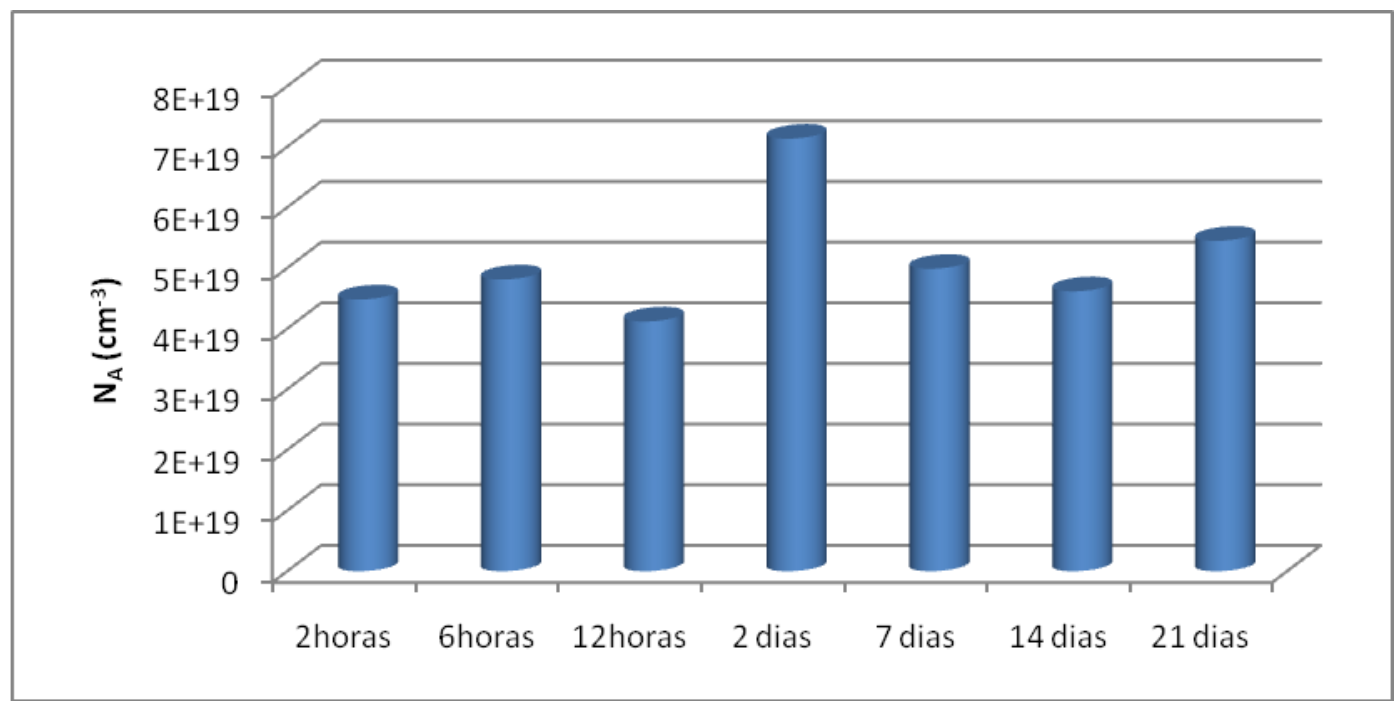

Figura 43 - Valores da concentração de aceitadores de carga no filme passivo do aço $316 \mathrm{~L}$, determinados a partir dos gráficos de Mott-Schottky da Figura 39 na região de potenciais entre $-1 \mathrm{~V}$ e $-0,4 \mathrm{~V}$.

Para o óxido semicondutor tipo-p não houve uma alteração significativa no número de dopantes entre 2 e 12 horas de imersão. Após 2 dias , assim como observado nos doadores de cargas, ocorreu um aumento do $\mathrm{N}_{\mathrm{A}}$ (aceitadores de 
carga) seguido por uma queda em 7 dias. De 7 dias até 21 dias não houve muita variação na concentração de dopantes. A diferença entre os valores de $\mathrm{N}_{\mathrm{A}}$ para 2 horas e 21 dias de imersão foi pouco expressiva, ao contrário da concentração de doadores.

$\mathrm{Na}$ Figura 44 tem-se a concentração de dopantes do filme passivo do aço $316 \mathrm{~L}$ tanto para os aceitadores quanto doadores de carga.

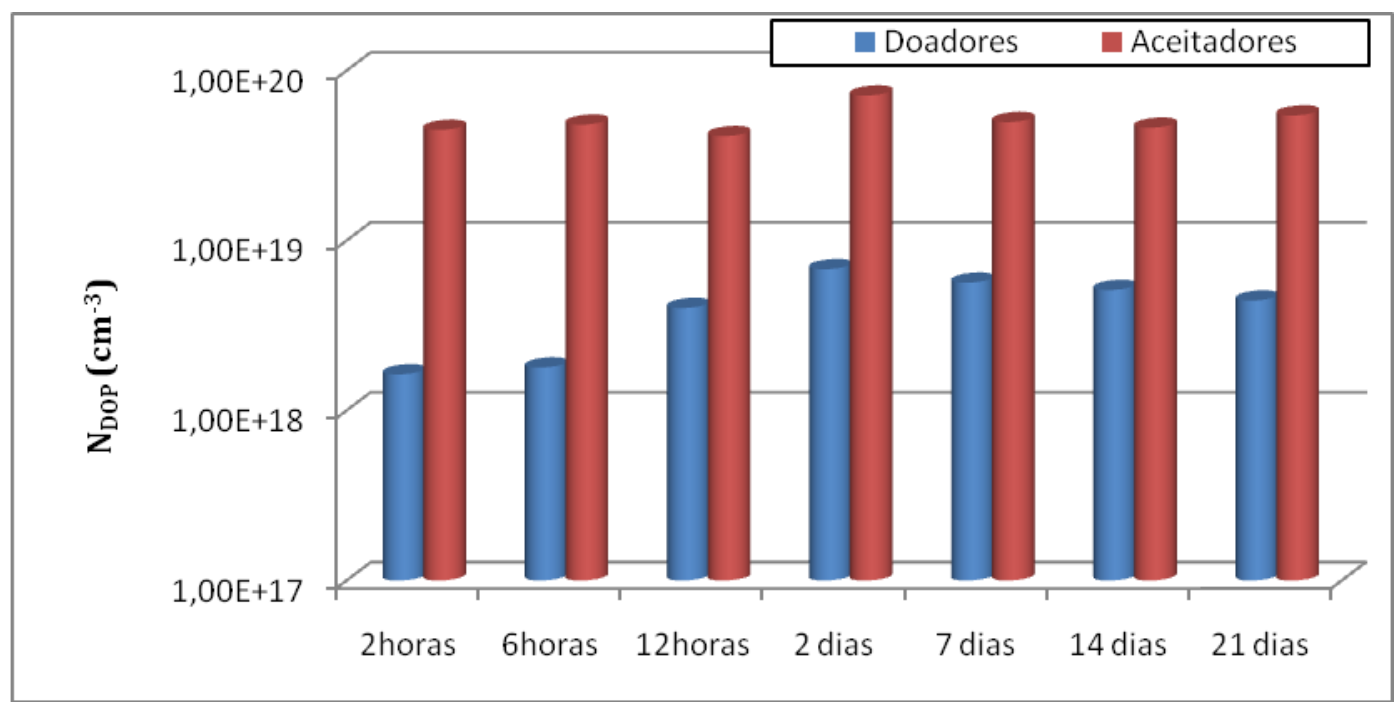

Figura 44 - Valores da concentração de dopantes no filme passivo do aço 316L, determinados a partir dos gráficos de Mott-Schottky (Figura 39).

A concentração de ambos os tipos de dopantes tem um pico em 2 dias de imersão e sofre redução progressiva até 21 dias. Isto significa que o filme passivo tornou-se menos condutor e defeituoso após 21 dias de imersão, em comparação com 2 dias. $\mathrm{O}$ mesmo resultado pode ser observado pelos valores dos elementos R-CPE $E_{\text {ext }}$ e R- $\mathrm{C}_{\text {int }}$ obtidos pelos ajustes por CEE dos diagramas de impedância.

\subsubsection{Aço PM2000}

Os gráficos de Mott-Schottky para o aço PM2000 após 2, 6, 12 horas e $2,7,14$ e 21 dias de imersão, em solução PBS naturalmente aerada à $25^{\circ} \mathrm{C}$, são mostrados na Figura 45. 


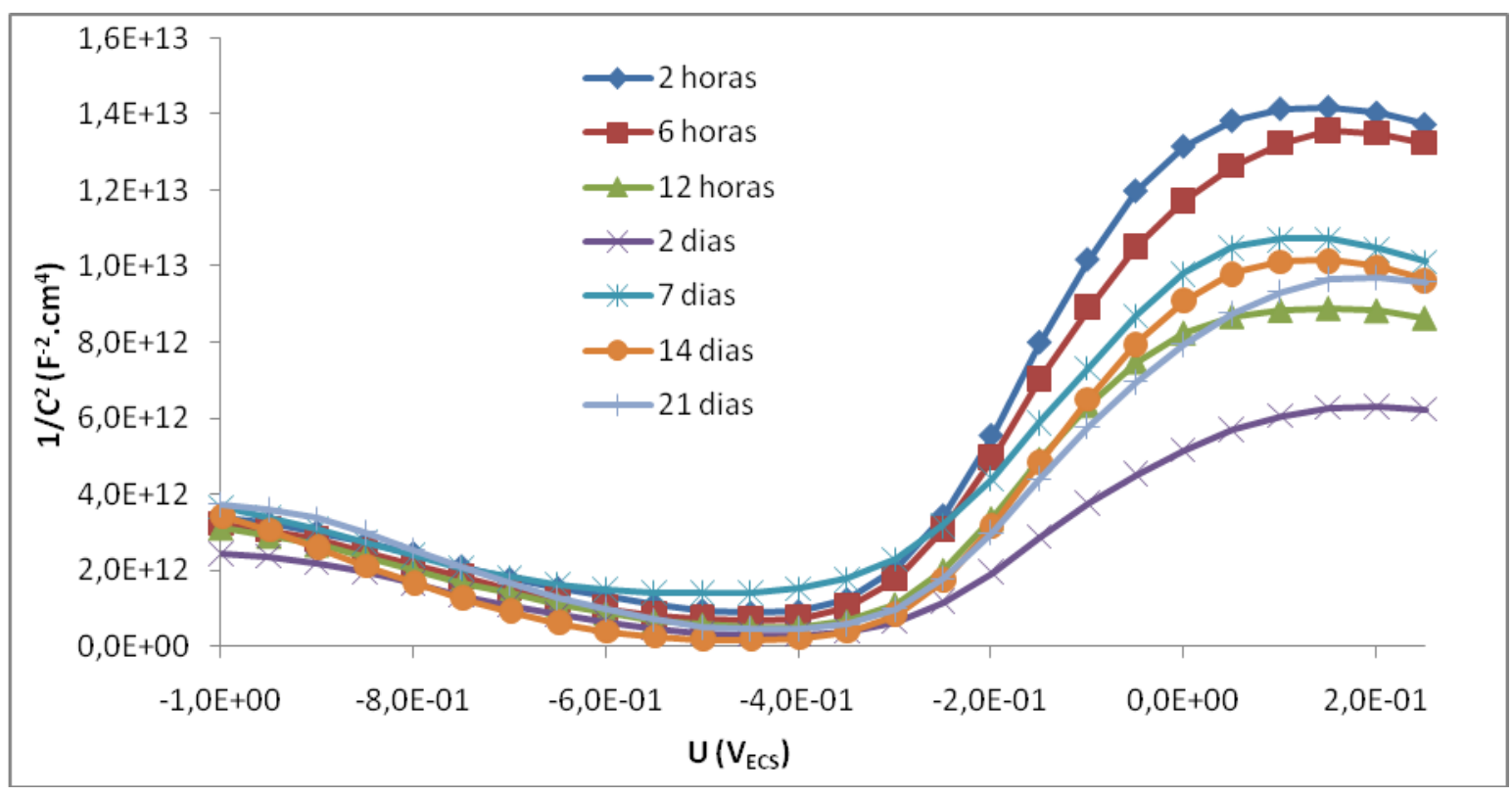

Figura 45 - Gráficos de Mott-Schottky para o aço PM2000 após diferentes períodos de imersão, em solução PBS naturalmente aerada à $25^{\circ} \mathrm{C}$.

Observando-se as curvas obtidas pela técnica de Mott-Schottky para o aço PM2000 (Figura 45), verifica-se um comportamento típico de um filme passivo dúplex, cujos óxidos apresentam comportamento de um semicondutor extrínseco tipo-n, na região de potencial entre $-0,4 \mathrm{~V}$ e $+0,25 \mathrm{~V}$, e comportamento de um semicondutor extrínseco tipo-p, na faixa de potencial entre $-1 \mathrm{~V}$ e $-0,4 \mathrm{~V}$.

potencial de banda plana foi próximo à $-0,4 \mathrm{~V}$ em todos os períodos de imersão, o que está condizente com os valores encontrados na literatura.

Nas curvas referentes à capacitância de um semicondutor tipo-n (entre $0,4 \mathrm{~V}$ e $+0,25 \mathrm{~V}$ ) a maior inclinação foi verificada em 2 horas de imersão. Seguida por uma queda sucessiva até 2 dias, quanto atingiu o menor valor. Para 7 dias de imersão houve um aumento na inclinação, que se manteve praticamente estável até o término do ensaio.

$\mathrm{Na}$ região de potencial entre $-1 \mathrm{~V}$ e $-0,4 \mathrm{~V}$, observa-se uma inclinação cerca de uma ordem de grandeza inferior às obtidas na faixa de potencial maior que $\circ U_{\mathrm{fb}}$. Devido a esta diferença de grandeza, ocorreu um achatamento das curvas, dificultando a visualização entre as mesmas. Na Figura 46 alterou-se a escala dos eixos $\mathrm{X}$ e $\mathrm{Y}$ para melhor visualização dos gráficos de Mott-Schottky, correspondentes ao inverso da capacitância dos óxidos semicondutores tipo-p. 


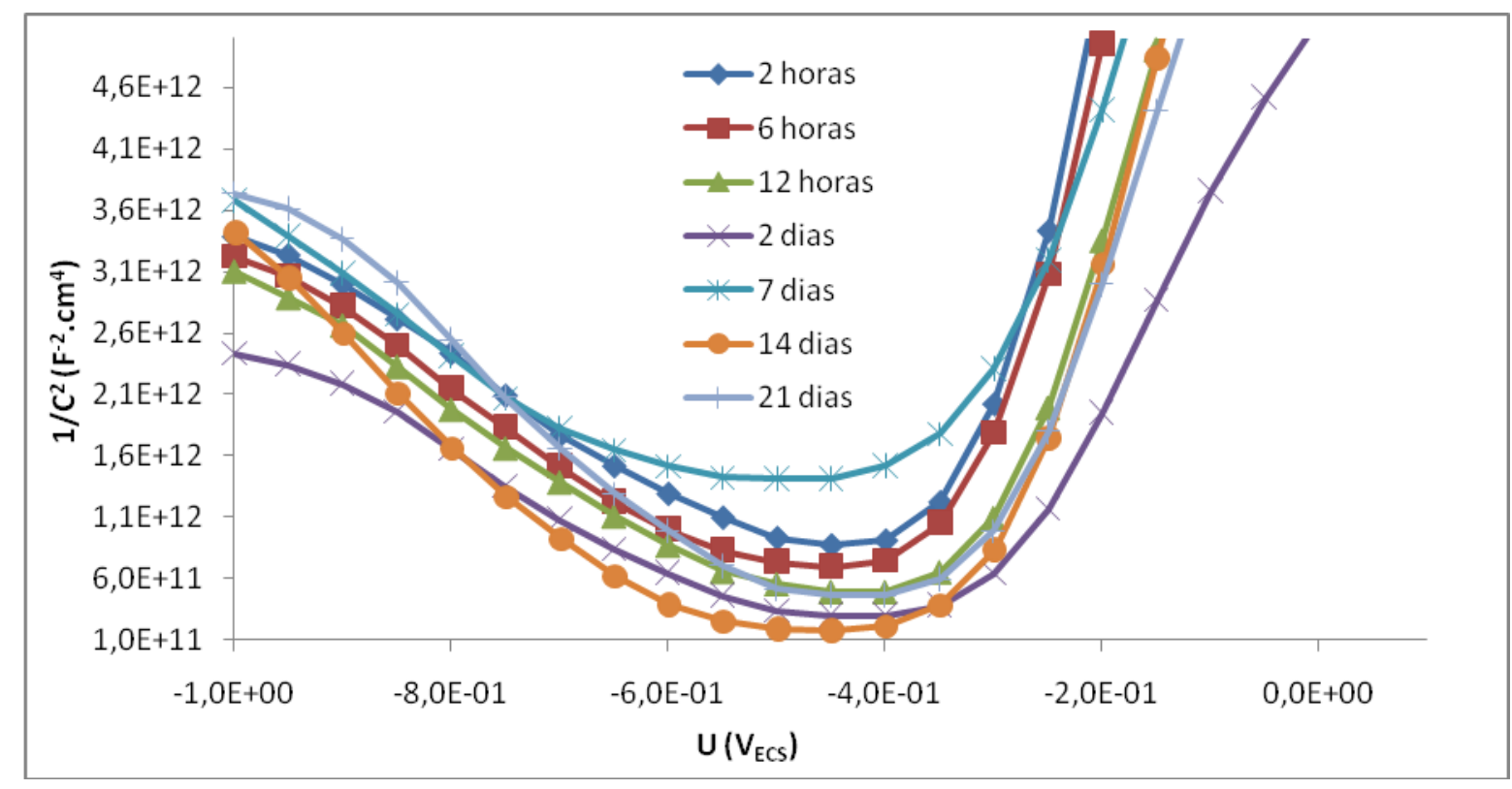

Figura 46- Gráficos de Mott-Schottky para o aço PM2000 após diferentes períodos de imersão, em solução PBS naturalmente aerada à $250 \mathrm{C}$.

Na faixa de potencial $<\mathrm{U}_{\mathrm{fb}}$, observa-se o maior valor de inclinação após 21 dias, sendo este muito próximo ao obtido pela amostra de 2 horas. Após 2 dias de imersão, o óxido tipo-p do filme passivo apresentou a menor inclinação. No decorrer do ensaio, as amostras de 7, 14 e 21 dias obtiveram inclinações superiores às amostras iniciais de 6 e 12 horas.

Tendo por base as curvas de Mott-Schottky (Figura 45), foram calculadas as densidades de doadores de carga das amostras do aço PM2000 no decorrer do experimento (Figura 47).

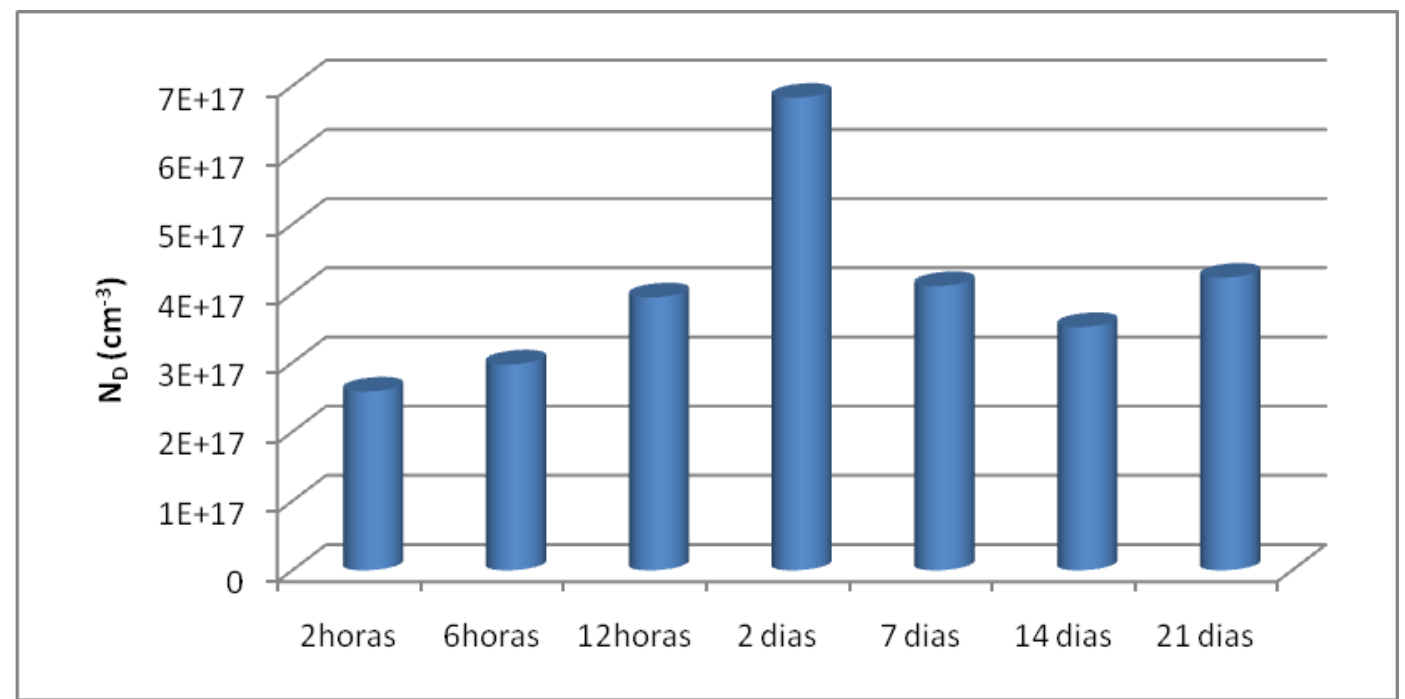

Figura 47 - Valores da concentração de doadores de carga no filme passivo do aço PM2000, determinados a partir dos gráficos de Mott-Schottky (Figura 45) na região de potenciais entre $-0,4 \mathrm{Ve}+0,25 \mathrm{~V}$. 
As concentrações de dopantes do óxido externo semicondutor tipo-p, mostradas na Figura 47, indicam que o filme passivo tornou-se menos condutor após 21 dias, em comparação com 2 horas. Houve um pico no número de dopantes em dois dias, sugerindo um maior número de defeitos no filme neste período de imersão relacionado à formação de lacunas de íons metálicos. A pequena variação na concentração de doadores de carga, entre 7 e 21 dias, indicam que a camada externa do filme atinge a estabilidade no meio ensaiado e permanece passivo.

Com as inclinações obtidas nos diagramas de Mott-Schottky (Figura 45), foram calculadas as concentrações de aceitadores de carga para a camada interna das amostras do aço PM2000, entre 2 horas e 21 dias de imersão na solução PBS.

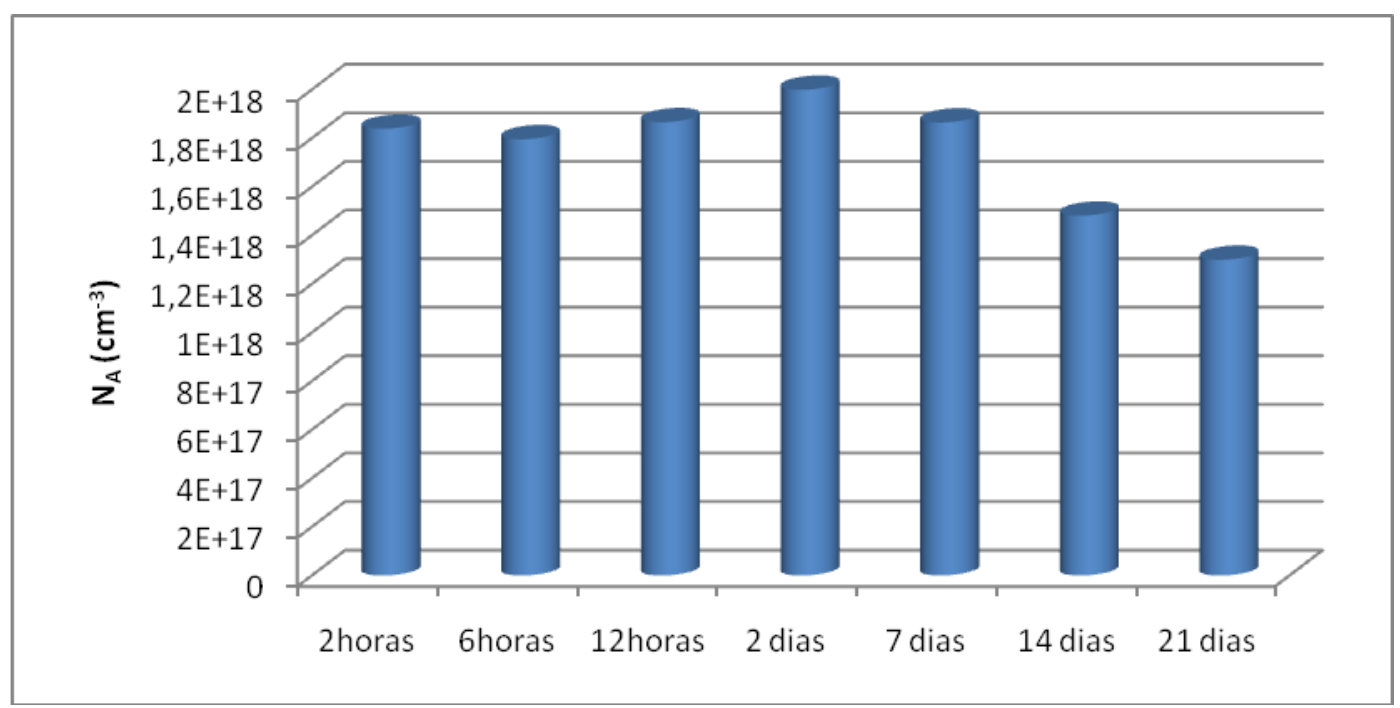

Figura 48 - Valores da concentração de aceitadores de carga no filme passivo do aço PM2000, determinados a partir dos gráficos de Mott-Schottky (Figura 45) na região de potenciais entre $-1 \mathrm{~V}$ e $-0,4 \mathrm{~V}$.

A densidade de dopantes das amostras do aço PM2000 apresenta apenas uma pequena variação entre 2 e 12 horas. Após 2 dias verifica-se um pico na concentração de aceitadores de carga, seguido por um decréscimo sucessivo até atingir o menor valor em 21 dias. A variação de valores entre o início e o fim do experimento foi de $1,83 \times 10^{18}$ dopantes $/ \mathrm{cm}^{3}$ (2 horas) para $1,29 \times 10^{18}$ dopantes $/ \mathrm{cm}^{3}$ (21 dias).

Na Figura 49 tem-se a concentração de dopantes do filme passivo do aço PM2000 tanto para os aceitadores quanto doadores de carga. 


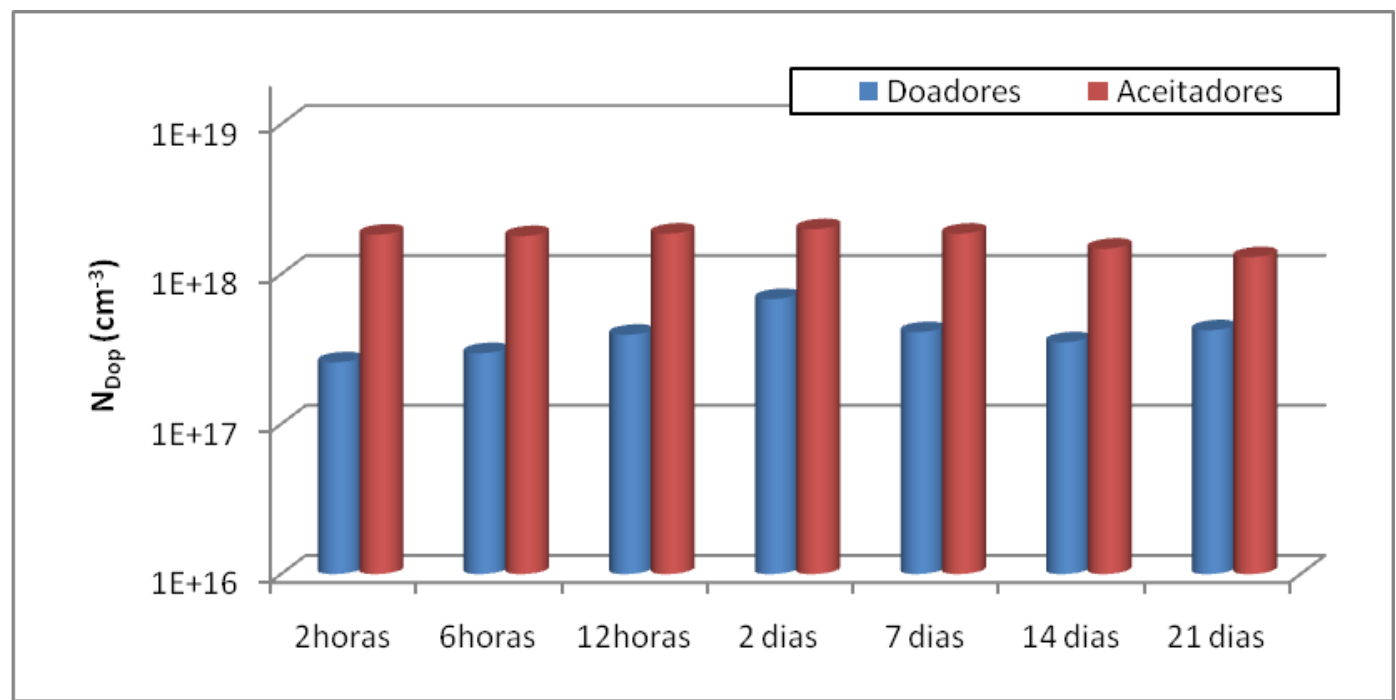

Figura 49 - Valores da concentração de dopantes no filme passivo do aço PM2000, determinados a partir dos gráficos de Mott-Schottky (Figura 45).

As densidades de dopantes (Figura 49) mostraram que houve uma diminuição tanto de doadores quanto de aceitadores entre 2 e 21 dias de imersão. Assim, pode-se supor que o filme de óxido sobre o aço PM2000 tornou-se menos desordenado tanto em sua camada externa (rica em óxido de ferro) como interna (rica em óxido de cromo). Esta desordem seria relacionada a um número mais alto de defeitos no filme, ou seja, de buracos eletrônicos na interface metal/filme e de lacunas de íons metálicos na interface filme/eletrólito. Consequentemente, o filme passivo torna-se menos condutor com o tempo de imersão o que pode ocasionar um aumento do comportamento capacitivo do aço PM2000. Os dados experimentais de espectroscopia de impedância eletroquímica confirmam que há um aumento do caráter capacitivo do sistema em baixa freqüência e aumento da impedância entre 2 e 21 dias de imersão. Este comportamento pode ser observado nos diagramas de Bode e Nyquist e também nos valores de resistência da camada interna $\left(R_{\text {int }}\right)$ e externa $\left(R_{\text {ext }}\right)$ do filme passivo obtidos pelo ajuste dos dados ao CEE proposto.

5.6.3 Comparativo entre os diagramas de Mott-Schottky dos aços 316L e PM2000 Os gráficos de Mott-Schottky para o aço PM2000 e 316L após 2, 6, 12 horas e 2, 7, 14 e 21 dias de imersão, em solução PBS naturalmente aerada à 25ำ C, são mostrados na Figura 50. 


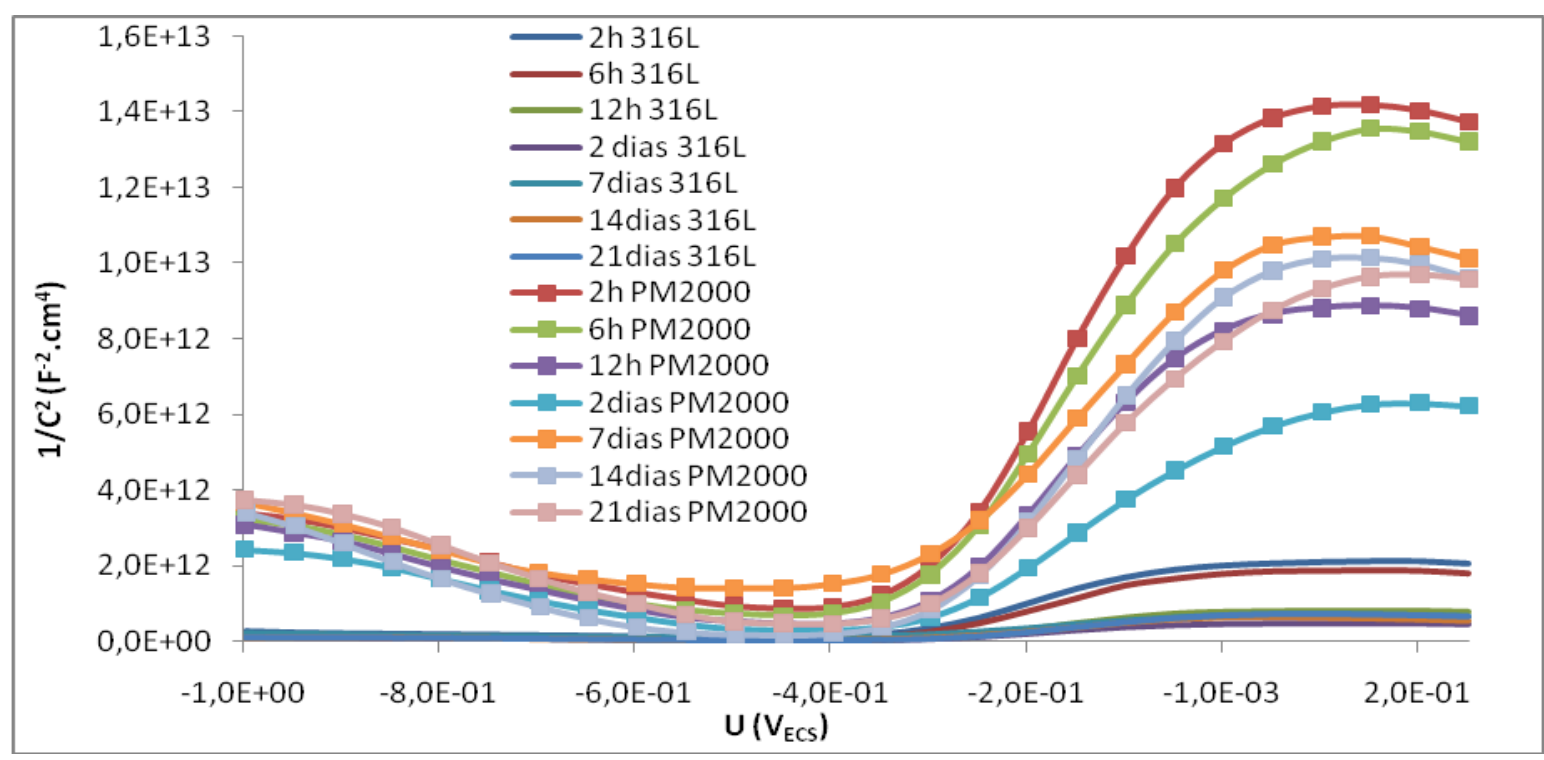

Figura 50 - Gráficos de Mott-Schottky para o aço PM2000 e 316L após diferentes períodos de imersão, em solução PBS naturalmente aerada à 25ํㅡ.

Pelos diagramas de Mott-Schottky da Figura 50, pode-se observar claramente que as curvas relativas ao aço PM2000 apresentam inclinações superiores às obtidas pelo aço 316L. Devido a esta diferença, as curvas do aço 316 L ficam achatadas quando apresentadas junto com as do PM2000. Como esta variação da inclinação, referente às regiões de comportamento tipo-p e tipo-n, pode ser relacionada às alterações na concentração de portadores de carga no filme passivo, uma diminuição da mesma está associada a um aumento do número de dopantes e vice-versa.

Na Figura 51 é apresentada a densidade de aceitadores de carga para os aços PM2000 e 316L em diferentes períodos de imersão.

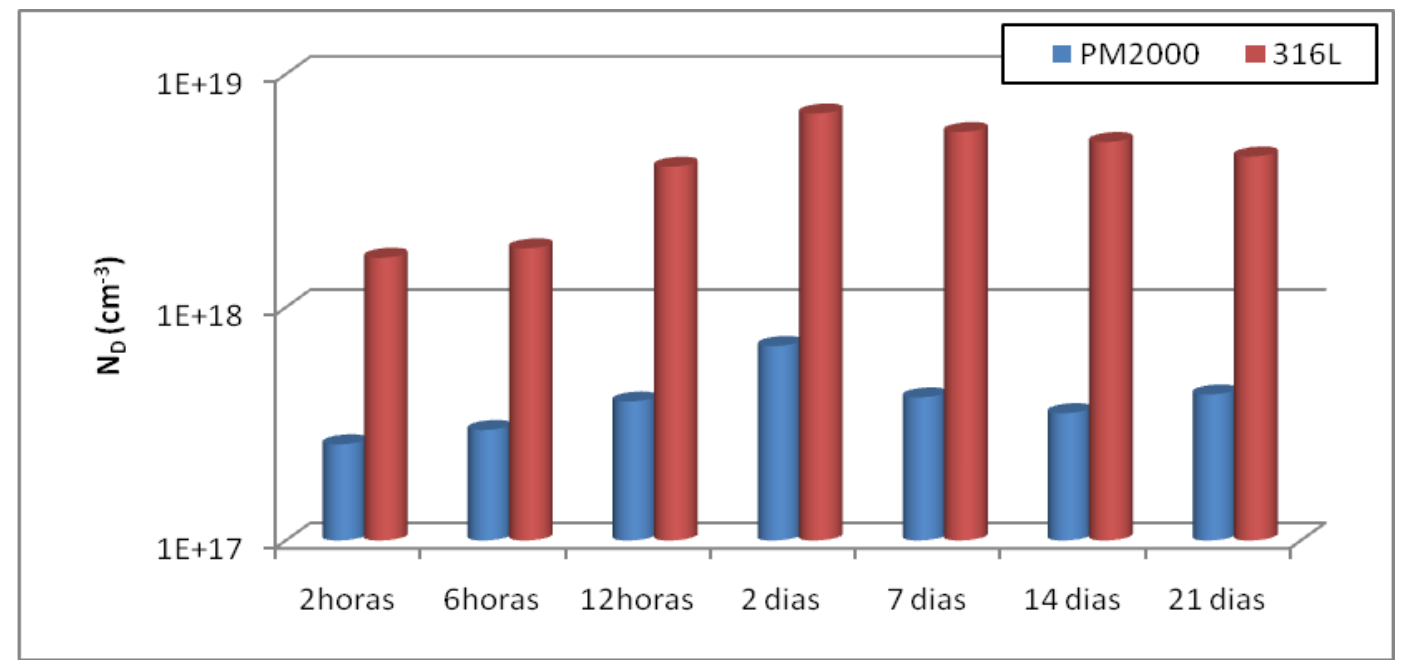

Figura 51 - Valores da concentração de doadores de carga no filme passivo dos aços PM2000 e 316L, determinados a partir dos gráficos de Mott-Schottky (Figura 50) na região de potenciais entre $-0,4 \mathrm{~V}$ e +0,25 V. 
Pelos resultados da Figura 51, observa-se que a concentração de doadores de carga (óxido semicondutor tipo-n) apresenta diferença ao redor de uma ordem de grandeza quando se compara os dois aços testados, em todos os períodos. Esta Figura mostra que as concentrações de dopantes na camada externa do filme aumentaram até 2 dias, de imersão, apresentando pequena diminuição após este período, seguida de estabilização. Estes resultados sugerem que o filme de óxido externo sobre os aços PM2000 e 316L torna-se mais desordenado com o aumento do tempo até 2 dias de imersão. Esta desordem está relacionada a um número mais alto de defeitos intrínsecos, neste caso, de lacunas de íons metálicos na interface filme/eletrólito. Como o aço 316L é cerca de 10 vezes mais dopado, pode-se assumir que seu filme é mais defeituoso na mesma proporção.

Na Figura 52 são mostrados os resultados calculados para a densidade de aceitadores de carga para os aços PM2000 e 316L.

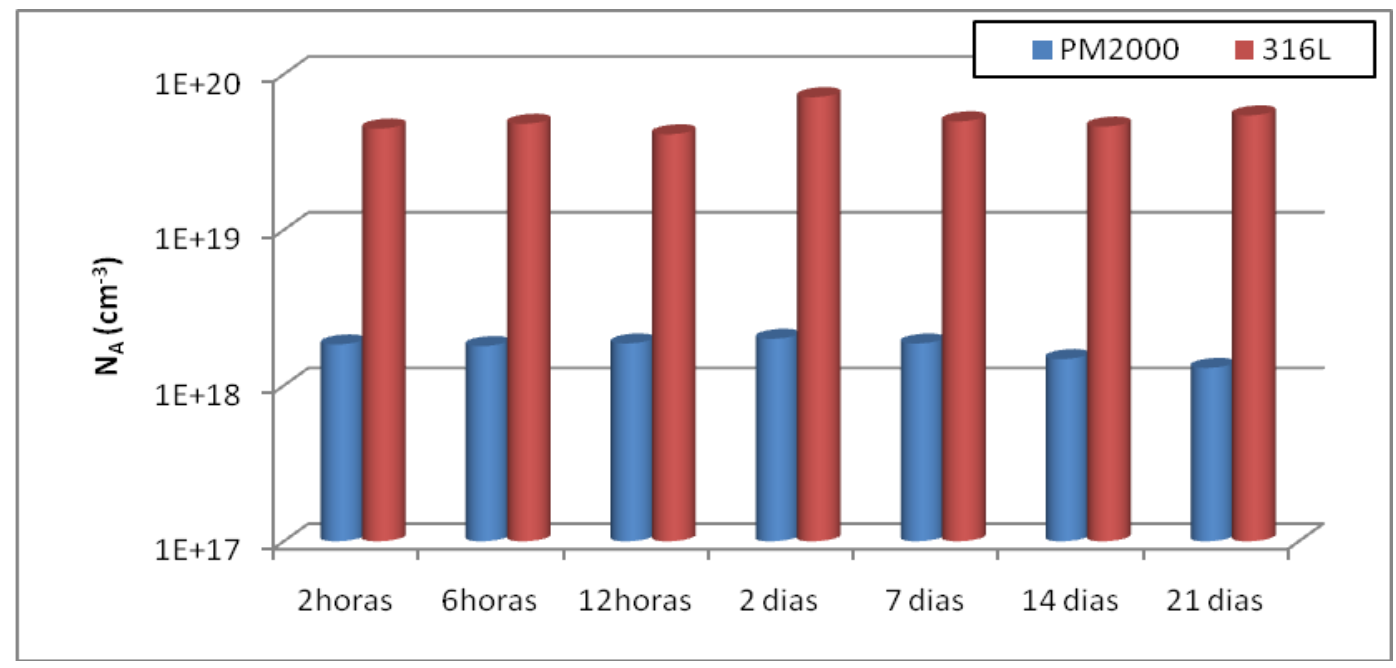

Figura 52 - Valores da concentração de aceitadores de carga no filme passivo dos aços PM2000 e 316L, determinados a partir dos gráficos de Mott-Schottky (Figura 50) na região de potenciais entre $-1 \mathrm{~V}$ e $-0,4 \mathrm{~V}$.

As concentrações de dopantes entre o período de 2 e 21 dias, tanto para um semicondutor tipo-n como para um tipo-p, mostraram uma diminuição de doadores na camada externa e de aceitadores na interna (Figura 51 e Figura 52, respectivamente). A concentração de dopantes, neste intervalo, revela uma diminuição na condutividade do filme, o que resulta em um aumento no comportamento capacitivo. Isto está em acordo com os dados experimentais de 
EIE que mostram o aumento do caráter capacitivo do sistema entre 2 e 21 dias de imersão.

Os valores próximos a $10^{19}$ dopantes $/ \mathrm{cm}^{3}$ para o aço $316 \mathrm{~L}$ estão uma ordem de grandeza abaixo dos relatados por MONTEMOR et al. (2000). Para o aço PM2000, os valores da ordem de $10^{18}$ dopantes $/ \mathrm{cm}^{3}$ indicam que este material, em meio PBS, apresenta um filme menos defeituoso por duas ordens de grandeza que os estudados por HAKIKI et al. em 1995 (aço 304 e ligas Fe-Cr), por MONTEMOR et al. em 2000 (316L e ligas de níquel) e por CASTRO E VILCHE em 1993 (Ligas de Fe e Fe-Cr).

\subsection{Análise da composição química superficial da liga PM2000 por XPS}

A análise por XPS do filme passivo formado sobre a liga PM2000 foi feita com o objetivo de se determinar a composição química superficial.

A quantificação das espécies químicas presentes no filme passivo foi obtida após a análise das ionizações principais, considerando-se as formas oxidadas e metálicas do $\mathrm{Fe}, \mathrm{Cr}$, Al e também as diferentes espécies de oxigênio e ítrio presentes. A Figura 53 apresenta os resultados obtidos para o $\mathrm{Fe}$ (III) e $\mathrm{Cr}$ (total) da liga PM2000 após 2, 7, 14 e 21 dias de imersão em solução PBS.

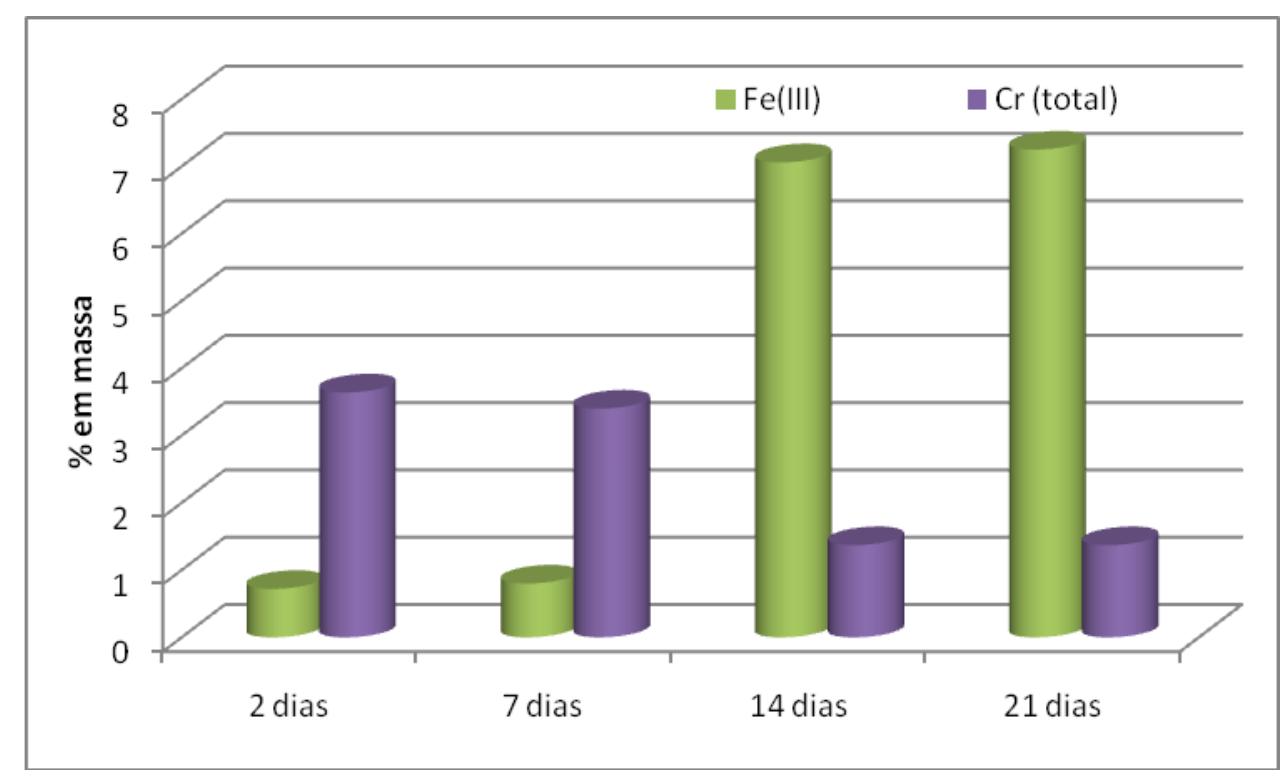

Figura 53 - Análise quantitativa por XPS de Fe (III) e Cr (total) na superfície da liga PM2000 após 2, 7, 14 e 21 dias de imersão em PBS.

Nos resultados apresentados na Figura 53 observa-se que, com 0 decorrer do período de imersão, há uma diminuição do teor de $\mathrm{Cr}$ (total) e 
aumento no de Fe (III). Como a técnica de XPS empregada não incluiu o desbaste da superfície para análise das camadas, os resultados apresentados correspondem aos elementos presentes na camada mais externa do filme passivo. Isto indica o enriquecimento em óxido e hidróxidos de Fe desta camada, conforme é sugerido na literatura para a camada externa do filme passivo de aços inoxidáveis. Ao mesmo tempo, a contribuição de $\mathrm{Cr}$ (total) na camada mais externa diminuiu no decorrer do ensaio.

A Figura 54 apresenta os resultados obtidos para $\mathrm{Y}$ e Al (total) na superfície da liga PM2000 após 2, 7, 14 e 21 dias de imersão em PBS.

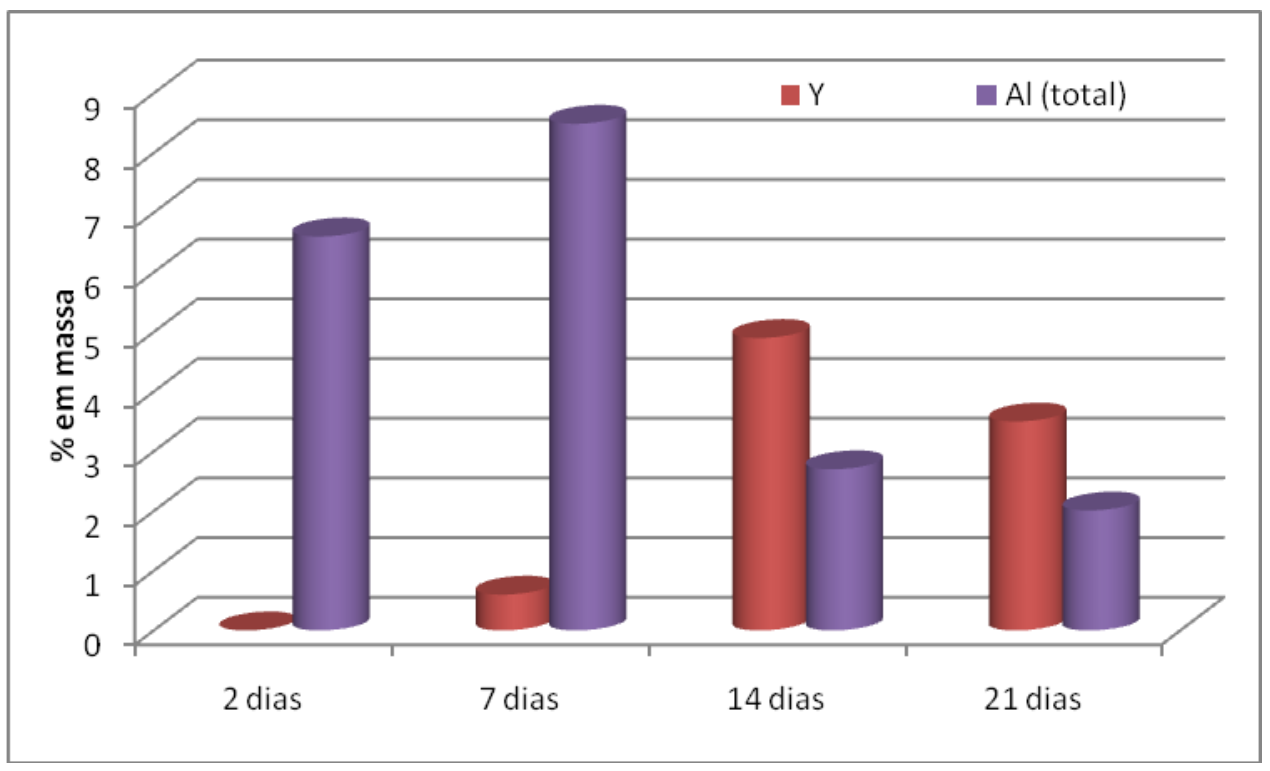

Figura 54 - Análise quantitativa por XPS para o Y e Al (total) na superfície da liga PM2000 após 2, 7, 14 e 21 dias de imersão em PBS.

Os resultados da Figura 54 mostram que a camada externa torna-se enriquecida em Y com o tempo de imersão. Os primeiros vestígios da presença de ítrio no filme passivo surgem em 2 dias. Após 7 dias há uma nítida definição da presença de ítrio na camada externa, sugerindo que com o tempo, o Y presente na liga se difunde para a parte mais externa do filme. Após 14 dias, a contribuição de ítrio na camada mais externa já é superior à do alumínio, o mesmo ocorrendo para 21 dias de imersão, embora tenha se observado uma pequena diminuição nos teores destes dois elementos. Com relação ao Al, até 7 dias o teor deste elemento é muito elevado, mas a contribuição deste é reduzida sensivelmente entre 7 e 21 dias, o que pode ocorrer em conseqüência da predominância da difusão do ítrio para a camada externa em relação à do alumínio. 
A liga PM2000 foi desenvolvida para aplicação em altas temperaturas e, por este motivo, são adicionados a ítria e o alumínio como componentes da liga. A ítria desempenha um papel importante nos processos de oxidação em alta temperatura uma vez que ela altera o processo de difusão de cátions e aumenta a taxa de crescimento da camada superficial de alumina (CZYRSKAFILEMONOWICZ et al, 1995).

Segundo RAMANATHAN (1993) adições inferiores a 0,1\% (em massa) de certos elementos altamente reativos, como as terras-raras, reduzem a taxa de oxidação e aumentam a adesão entre as camadas das ligas usadas em altas temperaturas. A alumina, que se forma na superfície da liga PM2000 após tratamento térmico, é uma biocerâmica altamente inerte e resistente aos mais corrosivos meios. Estas características motivaram o estudo do PM2000 por PÉREZ et al (2000) como potencial candidato para aplicações em implantes médicos

A Figura 55 apresenta os resultados obtidos por XPS para $\mathrm{O}^{2-}, \mathrm{OH}^{-}$, e $\mathrm{H}_{2} \mathrm{O}$ na superfície da liga PM2000 para diversos períodos de imersão em PBS.

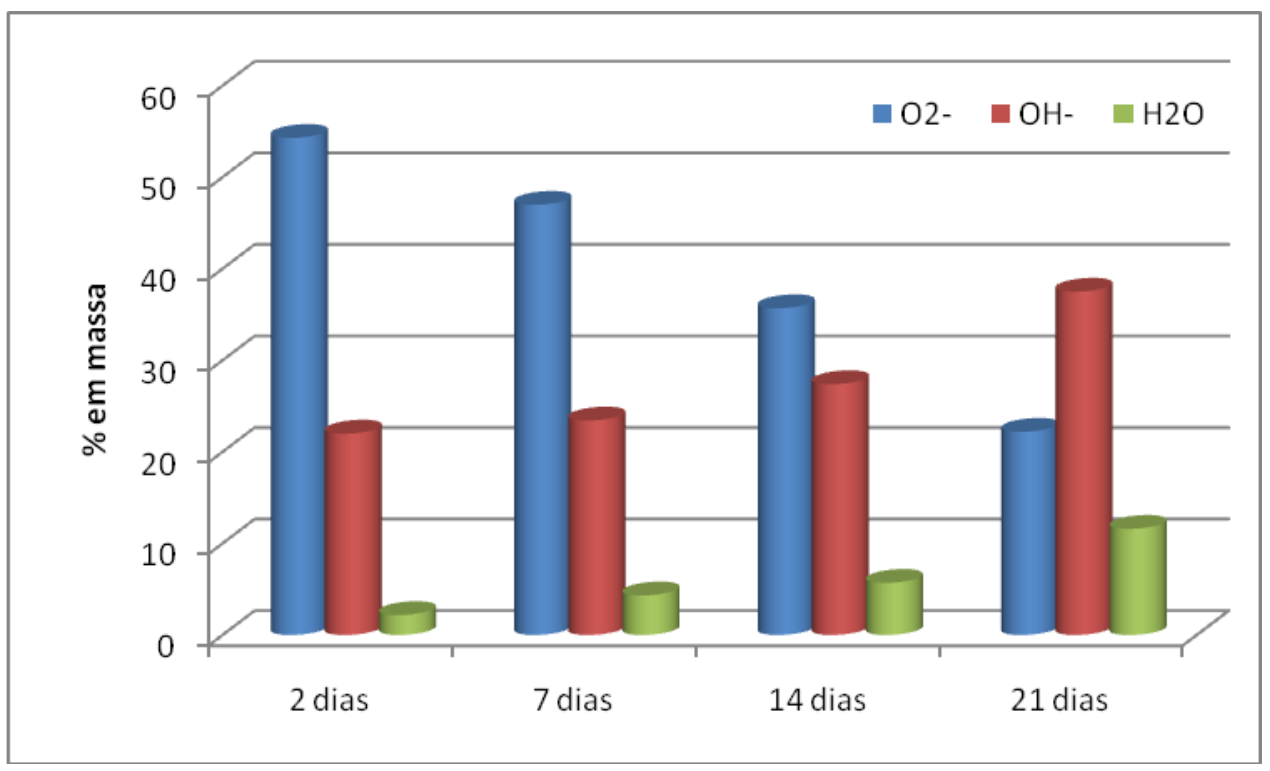

Figura 55 - Análise quantitativa por XPS para o $\mathrm{O}^{2-}, \mathrm{OH}^{-}$, e $\mathrm{H}_{2} \mathrm{O}$ na superfície da liga PM2000 após 2, 7, 14 e 21 dias de imersão em PBS.

Conforme os resultados observados na Figura 55, a contribuição relativa de óxidos predomina sobre os hidróxidos até 14 dias de imersão. Para 21 dias de imersão a contribuição de hidróxidos na camada mais externa já era superior à dos óxidos. Durante todo o período de ensaio a porcentagem de óxidos 
no filme diminui, enquanto a de hidróxido aumenta Os resultados mostram a crescente tendência à hidratação das camadas mais externas do filme superficial com o tempo de imersão.

O PM2000 apresenta em sua composição química alumínio, titânio e ítria, além do cromo e do ferro (Tabela 3). A partir da análise quantitativa por XPS foi possível verificar que os elementos de liga contribuíram sensivelmente na composição das camadas mais externas, pois além da presença de óxidos e hidróxidos de ferro e de cromo foram detectados alumínio e ítria.

Apesar de ter sido realizada uma pesquisa bibliográfica no sentido de se encontrar referências sobre o papel do ítrio nas propriedades do filme passivo formado em soluções fisiológicas e à temperatura ambiente, não se encontrou publicações sobre este tema. Os resultados de XPS do presente trabalho, todavia, mostram a contribuição crescente deste elemento nas camadas mais externas do filme óxido. Estudos adicionais deveriam ser realizados para investigar o efeito da adição deste.

Os resultados dos ajustes dos diagramas de EIE por CEE (tabelas $9 \mathrm{e}$ 10) indicam uma pequena deterioração das propriedades protetoras da camada mais externa do filme sobre a liga PM200 entre 2 e 21 dias, período no qual se observou também a crescente hidratação e maior contribuição de ítrio e de hidróxidos nesta camada. É interessante observar que o titânio, apesar de presente na composição da liga, não foi detectado na superfície da amostra por XPS. Em trabalhos futuros, pode-se sugerir uma investigação mais detalhada deste fato, possivelmente com a utilização da espectroscopia fotoelétrica por raios-X, em conjunto com um desbaste da superfície ("sputtering"), para analisar as camadas menos superficiais do óxido formado sobre a liga PM2000. 


\section{CONCLUSÕES}

Com base nos resultados obtidos, pode-se chegar às seguintes conclusões:

- Os materiais estudados não apresentam citotoxicidade in vitro.

- A força de retenção magnética relativa aferida de todos os materiais foi superior a do grupo controle.

- Os resultados obtidos por EIE, para os aços PM2000, 17-4PH PIM, $1802 \mathrm{e}$ $316 \mathrm{~L}$, mostraram que todos os materiais apresentam comportamento passivo sob as condições de estado estacionário adotadas neste estudo. A película passiva formada na superfície dos materiais é mais protetora após 21 dias de imersão, quando comparada com 2 dias.

- A resistência à corrosão por pite do aço PM2000, determinada por polarização potenciodinâmica anódica, foi superior à do aço $316 \mathrm{~L}$ utilizado como controle. O mesmo comportamento foi observado pelo ensaio de polarização anódica adotando o método stair-step.

- Os valores de potenciais de pite dos aços 1802 e 17-4PH PIM, obtidos por polarização anódica potenciodinâmica e "stair-step", mostraram que estes materiais apresentaram maior tendência à corrosão por pite que o aço $316 \mathrm{~L}$.

- Os diagramas de Mott-Schottky indicaram que o filme passivo superficial do aço PM2000 é menos dopado que o filme do aço 316 em pelo menos uma ordem de grandeza sendo o primeiro, portanto, menos defeituoso que o último.

- Os resultados de XPS mostraram a formação de um óxido superficial com uma crescente contribuição de ítrio e hidróxidos na camada mais externa, no decorrer do período de imersão. Também ocorre uma maior concentração de $\mathrm{Fe}$ (III) e diminuição do $\mathrm{Cr}$ (total) desta camada.

- Os resultados indicaram o aço PM2000 como um potencial candidato para aplicação em conectores protéticos ferromagnéticos. 


\section{SUGESTÕES PARA TRABALHOS FUTUROS}

Como trabalhos futuros, são propostos:

1) Investigar a influência da ítria e alumina nas propriedades eletrônicas do filme passivo sobre a liga PM2000.

2) Estudo do comportamento eletroquímico da liga EFM, utilizada na fabricação de conectores ferromagnéticos.

3) Realizar ensaio de genotoxicidade no aço que apresentou melhores propriedades de resistência à corrosão.

4) Avaliar a resistência à corrosão em frestas do aço PM2000.

5) Avaliar a resistência à corrosão do aço PM2000 em solução PBS a 25ํㅡ C após tratamento térmico visando crescimento de óxido.

6) Análise da liga PM2000 por XPS após vários desbastes superficiais ("sputtering"). 


\section{REFERÊNCIAS BIBLIOGRÁFICAS}

AHN, S. J., KWON, H. S., Effects of solution temperature on electronic properties of passive film formed on $\mathrm{Fe}$ in $\mathrm{pH} 8.5$ borate buffer solution, Electrochimica Acta, v. 49, p. 3347-3353, 2004.

ANTUNES, R. A. Caracterização do comportamento frente à corrosão de um aço inoxidável austenítico para aplicações biomédicas com revestimentos PVD de TiN, TiCN e DLC. 2006. Tese (doutorado) - Instituto de Pesquisas Energéticas e Nucleares. São Paulo, 2006.

ASAMI, K., HASHIMOTO, K., SHIMODAIRA, S. XPS determination of compositions of alloy surfaces and surface oxides on mechanically polished ironchromium alloys. Corrosion Science, v. 17, n. 7, pp. 713-723, 1977.

ASSIS, S. L. Investigação da resistência à corrosão da liga Ti-13Nb-13Zr por meio de técnicas eletroquímicas e de análise de superfície. Tese (doutorado). Instituto de Pesquisas Energéticas e Nucleares, São Paulo, 2006.

BECKER, J.J. Permanent magnets. Sci. Am., v.223, p.92-100, 1970.

BRUNDLE, C. R., EVANS, C. A., WILSON, S., Encyclopedia of Materials Characterization, Butterworth-Heinemann, 1992

BOJINOV, M., A Surface Charge Approach to the Growth and Relaxation in Anodic Passive Films on Metals, Materials Science Forum, v. 185-188, p. 601610, 1995.

BOJINOV, M, BETOVA, I., FABRICIUS, G., LAITINEN, T., RAICHEFF, R., SAARIO, T. The stability of the passive state of iron-chromium alloys in sulphuric acid solution. Corrosion Science. v. 41, n. 8, pp. 1557-1584, 1999.

BRUCE L. BRAMFITT, ARLAN O. BENSCOTER. Metallographer's guide: practices and procedures for irons and steels / ASM Handbook, ASM International, 2002, p. 1-16

CASTLE, J. E., CLAYTON, C. R., The use of X-ray photo-electron spectroscopy in the analyses of passive layers on stainless steel, Corrosion Science, v. 17, p. 726, 1977.

CASTRO, E. B, VILCHE, J. R., Investigation of passive layers on iron and ironchromium alloys by electrochemical impedance spectroscopy, Electrochimica Acta, v. 38, n. 11, p. 1567-1572, 1993.

CHAO, C. Y., LIN, L. F., MACDONALD, D. D., A point defect model for anodic passive films. I. Film growth kinetics, Journal of Electrochemnical Society, v. 128 , n. 6 , p. $1187-1194,1981$.

CHUNG, R.W.C.; SIU, A.S.C.; CHU, F.C.S.; CHOW, T.W. Magnet-retained auricular prosthesis with an implant-supported composite bar: A clinical report $\boldsymbol{J}$ Prosthet Dent, v. 89, p.446-9, 2003 
COSTA, I. ; CORREA, O. V. ; ROGERO, S. O. ; SAIKI, M. Estudo comparativo da ressitência à corrosão e citoxicidade do aço 17-4PH obtido por metalurgia convencional e por moldagem de pós por injeção. In: XVI CBECIMATCongresso Brasileiro de Engenharia e Ciência dos Materiais, 2004, Porto Alegre. XVI Congresso Brasileiro de Engenharia e Ciência dos Materiais, 2004. v. 1.

COSTA, I; FRANCO, C.V.; KUNIOSHI, C.T.; ROSSI, J.L. Corrosion resistance of Injection-molded 17-4PH steel in sodium chloride solution, Corrosion, v. 62, n.4, p. 357-365, 2006.

COSTA, I.; OLIVEIRA, M.C.L.; TAKIISHI, H.; SAIKI, M.; FARIA R.N. Corrosion behaviour of commercial NdFeB magnets - The effect of magnetization. Key Eng. Materials, v.189-191, p. 340-45, 2001

CZYRSKA-FILEMONOWICZ A., CLEMENS D., QUADAKKERS W. J. The effect of high temperature exposure on the structure and oxidation behaviour of mechanically alloyed ferritic ODS alloys. Journal of Materials Processing Technology, v. 53, n. 1-2, p. 93-100, 1995.

DEVGE, C., TJELLSTRÖM, A., NELLSTRÖM, H. Magnetic Resonance Imaging in patients with dental implants: a clinical report. The International Journal of Oral \& Maxillofacial Implants. v. 12, n. 3, 1997.

DA CUNHA BELO, M., RONDOT, B., COMPERE, C., MONTEMOR, M. F., SIMÕES, A. M. P., FERREIRA, M. G. S., Chemical composition and semiconducting behaviour of stainless steels passive films in contact with artificial seawater, Corrosion Science, v. 40, n. 2/3, p. 481-494, 1998.

DA CUNHA BELO, M., WALLS, M., HAKIKI, N. E., CORSET, J., PICQUENARD, E., SAGON, G., NOËL, D. Composition, structure and properties of the oxide films formed on the stainless steel $316 \mathrm{~L}$ in a primary type PWR environment. Corrosion Science, v. 40, n. 2-3, pp. 447-463, 1998.

DINATO, J.C.; POLIDO, W.D. Implantes osseointegrados : cirurgia e prótese. São Paulo : Artes Médicas, 2001.

Dyna Magnet Manual, Dyna Dental, Holanda - Disponível em: http://www.dynadental.com/picture/content/download/1603-

01.05\%20Dyna\%20Magnet\%20Manual\%20GB.PDF Acessado em 23/10/08

ENDO, K., SUSUKI, M., OHNO, H., Corrosion characteristics of ferric and austenitic stainless steels for dental magnetic attachment. Dent Mater J., v.19(1), p. 34-49, 2000

FEDERICK, D.R. A magnetically retained interim maxillary obturator. J. Prosthet. Dent., v. 36, p. 671-3, 1976.

FREDERICK, C.S.; DENG, F.L.; CHOW, T.W. Implant-tissue supported, magnetretained mandibular overdenture for an edentulous patient with Parkinson's disease: A clinical report J Prosthet Dent, v. 91, p. 219-22, 2004 
FLORES, D.A., CHOI, L.K., CARUSO, J.M., TOMLINSON, J.L., SCOTT, G.E., JEIROUDI, M.T. Deformation of metal brackets: a comparative study. Angle Orthod. v. 64, n. 4, p. 283-290, 1994.

FLORES, M.S.; CIAPETTI, G.; GONZÁLEZ-CARRASCO, J.L.; MONTEALEGRE, M.A.; MULTIGNER, M.; PAGANI, S.; RIVERO, G. Evaluation of magnetic behavior and in vitro biocompatibility of ferritic PM2000 alloy. J. Materials Science: Materials in Medicine, v. 15, p. 559-565, 2004.

GARONE NETTO, N.; CARVALHO, R.C.R.;RUSSO, E.M.A;SOBRAL, M.A.P. Introdução à dentística restauradora : diagnóstico, prevenção, proteção da polpa, hipersensibilidade dentinária, adesão, São Paulo, Santos, 2003.

GE, H. ZHOU, G., WU, W. Passivation model of 316 stainless steel in simulated cooling water and the effect of sulfide on the passive film. Applied Surface Science, v. 211, n. 1-4, pp. 321-334, 2003.

General datasheet of precison wire 1802, Sandivk, Suécia - Disponível em : http://www.smt.sandvik.com/sandvik/0140/internet/se01598.nsf/idea?OpenForm\& ParentUNID=33060426167A992BC1256ABC002A44E2 Acessado em 30/09/2008.

GENTIL, V. Corrosão. Rio de Janeiro: Editora Guanabara Dois.,1996. p. 432

GILLINGS, B.R.D. Magnetic retention for overdentires-Part II. J. Prosthet. Dent., v.49, p. 607-18, 1983.

GINESAN, P.; SMITH, G. D. Oxide scale formation on selected candidate combustor alloys in simulated gas turbine environments. Journal of Materials Engineering, v. 9, pp. 337-343, 1988.

GRANCHI, D., CENNI, E., CIAPETTI, G., SAVARINO, L, STEA, S., GAMBERINI, S., GORI, A., PIZZOFERRATO, A., Cell death induced by metal íons: necrosis or apoptosis?, Journal of Materials Science: Materials in Medicine, v. 9, p. 31-37, 1998.

HAKIKI, N., BAUDIN, S., RONDOT, B., DA CUNHA BELO, M., The electronic structure of passive films formed on stainless steels, Corrosion Science, v. 37, n. 11, p. 1809-1822, 1995.

HAKIKI, N. E., DA CUNHA BELO, M. Semiconducting properties of passive films formed on stainless steels. Influence of the alloying elements. Journal of Electrochemical Society, v. 145, n. 11, pp. 3821-3829, 1998.

HARRIS, I.R. Hard magnets. Mater. Science Technol., v.6, p. 962-6, 1990.

HENNEL, J. W.; KLINOWSKI, J. Fundamentals of Nuclear Magnetic Resonance - Longman Scientific \& Tecnical - Essex - England - 1993.

HIGHTON, R.; CAPUTO, A.A.; KINNI, M.; MATYAS, J. The interaction of a magnetically retained denture with osseointegrated implants. J. Prosthet. Dent., v.60, p. 486-90, 1988. 
HILLER,H.; WEISSBERG, N.; HOROWITZ, G.; ILAN, M. The safety of dental minimagnets in patients with permanent cardiac pacemakers. J. Prosthet. Dent., v.74, p.420-421, 1995.

ILEVBARE G. O., BURSTEIN, G. T. The role of alloyed molybdenum in the inhibition of pitting corrosion in stainless steels. Corrosion Science, v. 43, n. 3, p. 485-513, 2001.

IIMURO, F. T. Magnetic Resonance Artifacts and the Magnetic Attachment System. Dent Mat J, v. 13, n.1, p. 76-88, 1994.

ISO 10.993 - Biological evaluation of medical devices - part 5: Tests for cytotoxicity: in vitro methods, p. 1-7, 1992.

JACKSON, T.R.; HEALEY, K.W. Rare earth magnetic attachments: the state of the art in removable prosthodontics. Quint. Int., v.18, p. 41-51, 1987.

KITSUGI, A., OKUMO, O.; NAKANO, T; HAMANAKA, H.; KURODA, T. The corrosion behavior of NdFeB and Sm Co Magnets. Dent. Mat. J., v.11, n.2, p.11929, 1992.

KIM, Y. S., YOO, Y. R., SOHN, C. G., OH, K. T., KIM, K. N., YOON, J. H., KIM, H. $\mathrm{S}$., Role of alloying elements on the cytotoxic behavior and corrosion of austenitic stainless steels, Materials Science Forum, v. 475-479, p. 2295-2298, 2005.

KLUEH R.L., SHINGLEDECKER J.P., SWINDEMAN R.W., HOELZER D.T. Oxide dispersion-strengthened steels: A comparison of some commercial and experimental alloys. Journal of Nuclear Materials v. 341, p. 103-11, 2005.

KOIKE, M., TAKADA, Y., OKUNO, O., OKABE, T. Corrosion Characteristics of Dental Magnetic Attachments. Em: 7th International Conference on Magnetic Applications in Dentistry, 2008, Tokyo. The Japanese Society of Magnetic Applications in Dentistry. Disponível em: http://wwwsoc.nii.ac.jp/jmd/international/7th/S005/

LAVOS-VALERETO, I. C., WOLYNEC, S., RAMIRES, I., GUASTALDI, A. C., COSTA, I. Electrochemical impedance spectroscopy characterization of passive film formed on implant Ti-6Al-7Nb alloy in Hank's solution. Journal of Materials Science: Materials in Medicine, v. 15, n. 1, pp. 55-59, 2004.

LIN, L. F., CHAO, C. Y., MACDONALD, D. D., A point defect model for anodic passive films. II. Chemical breakdown and pit initiation, Journal of the Electrochemical Society, v. 128, n. 6, p. 1194-1198, 1981.

LOVRECEK, B., SEFAJA, J., Semiconducting aspects of the passive layer on chromium, Electrochimica Acta, v. 17, p. 1151-1155, 1972.

MANCINI, G.P.; NOAR, J.H.; EVANS, R. D. The physical characteristics of neodymium iron boron magnets for tooth extrusion. Euro. J. Of Orthod., v.21, p.541-550, 1999. 
MARTINI, E. M. A., MULLER, I. L., Characterization of the film formed on iron in borate solution by electrochemical impedance spectroscopy, Corrosion Science, v. 42, n. 3, p. 443-454, 2000.

MIYAO, M., KISHII, J., HIGASHINO, A. N. Y., IWAHORI, M., Clinical Observation of Magnetic Attachment, In: The 4th International Conference on Magnetic Applications in Dentistry, Japan, 2005

MONTEMOR, M. F., FERREIRA, M. G. S., HAKIKI, N. E., DA CUNHA BELO, M., Chemical composition and electronic structure of the oxide films formed on $316 \mathrm{~L}$ stainless steel and nickel based alloys in high temperature aqueous environments, Corrosion Science, v. 42, p. 1635-1650, 2000.

OKUNO, O., TAKADA, Y., KIKUCHI, M., KIMURA, K., Corrosion Resistance of Magnetic Stainless Steel Keeper for Dental Magnetic Attachment. Em: The First International Conference on Magnetic Applications in Dentistry, 2002, Tokyo. The Japanese Society of Magnetic Applications in Dentistry. Disponível em: http://wwwsoc.nii.ac.jp/jmd/international/1st/poster20i.shtml?20

$\mathrm{OH}$, K.T.; CHOO, S.U.; KIM, K.M.; KIM, K.N. A stainless steel bracket for orthodontic application. Eur J Orthod, v. 27, n. 3, p. 2370244, Jun. 2005.

OLSSON, C. -O. A., LANDOLT, D., Passive films on stainless steels - chemistry, structure and growth, Electrochimica Acta, v. 48, p. 1093-1104, 2003.

PÉREZ, F. J., HIERRO, M. P., GÓMEZ, C., MARTínEZ, L., VIGURI, P. G., Ion implantation as a surface modification technique to improve localized corrosion of different stainless steels. Surface and Coatings Technology, v. 151, p. 250-259, 2002.

PÉREZ, P.; HAANAPPEL, V. A. C.; STROOSNIJDER, M. F. Formation of an alumina layer on A FeCrAlY alloy by thermal oxidation for potential medical implant applications. Surface and Coatings Technology, v. 139, n. 2-3, p, 207215, 2001.

RAMANATHAN L.V., Role of rare-earth elements on high temperature oxidation behavior of Fe---Cr, Ni---Cr and Ni---Cr---Al alloys. Corrosion Science, v. 35, n. 5-8, p. 871-875, 877-878, 1993.

ROGERO, S. O., LUGAO, A. B.; IKEDA, T. I., CRUZ, A. S., Teste in vitro de citotoxicidade: estudo comparativo entre duas metodologias, Materials Research, v. 6, p. 317-320, 2003.

RONDELLI, G., TORRICELLI, P., FINI, M., GIARDINO, R. In vitro corrosion study by EIS of a nickel-free stainless steel for orthopedic applications. Biomaterials, v. 26, n. 7, pp. 739-744, 2005.

SALIBA-SILVA, A.; FARIA, R. N.; BAKER, M.A.; COSTA, I. Improving the corrosion resistance of NdFeB magnets: an electrochemical and surface analytical study. Surface \& Coatings Technology, v. 185, p. 321-328, 2004.

SATO, N., An overview on the passivity of metals, Corrosion Science, v. 31, p. 119, 1990. 
SAYGILI, G.; SAHMALI, S. Retentive forces of two magnetic systems compared with two precision attachments. J. Oral Sci., v. 40, n.2, p.61-4, 1998.

SCHULTZE, J. W., LOHRENGEL, M. M., Stability, reactivity and breakdown of passive films. Problems of recent and future research, Electrochimica Acta, v. 45, p. 2499-2513, 2000.

SCHMUKI, P., BÖHNI, H. Metastable Pitting and Semiconductive Properties of Passive Films. J. Electrochem. Soc., V, 139(7), p. 1908-1913, 1992.

SEDRIKS, A. J. Corrosion of Stainless Steel. New York: John Wiley, 1979.

SHAHRYARI, A., OMANOVIC, S. Improvement of pitting corrosion resistance of a biomedical grade 316LVM stainless steel by electrochemical modification of the passive film semiconducting properties. Electrochemistry Communications, v. 9, n. 1, pp. 76-82, 2007.

SIEGBAHN, K., Electron spectroscopy - an outlook, Journal of Electron Spectroscopy and Related Phenomena, v. 5, p. 3-97, 1974

SUMITA, M., IKADA, Y., TATEISHI T., Editors, Metallic BiomaterialsFundamentals and Applications, ICP, Tokyo (2000), p. 629.

TAKADA, Y., TAKAHASHI, N., OKUNO O., Electrochemical behavior and released ions of the stainless steels used for dental magnetic attachments. Em: 6th International Conference on Magnetic Applications in Dentistry, 2007, Tokyo. The Japanese Society of Magnetic Applications in Dentistry. Disponível em: http://wwwsoc.nii.ac.jp/jmd/international/6th/S011/

THOMAS, K.F. Freestanding magnetic retention for extraoral prosthesis with osseointegrated implants J. Prosthet. Dent, v. 73, p. 162-5, 1995

TURANO, J.C.; TURANO. L.M. Fundamentos de prótese total. Chicago : Quintessence, 1988.

WAMSLEY, A.D. Magnetic Retention in Prosthetic Dentistry. Dent. Update, v.29, p.428-33, 2002.

WINKLER, S. The effectiveness of embedded magnets on complete dentures during speech and mastigation: a cineradiographic study. Dent Digest, v. 73, p. 118-25, 1967.

WOLYNEC, S. Técnicas eletroquímicas em corrosão, EDUSP, São Paulo, 2003.

ZANETTI, A.L.; LAGANÁ, D.C. Planejamento: prótese parcial removível. $2^{a}$.ed. São Paulo, Sarvier, 1996. 


\section{ANEXO}

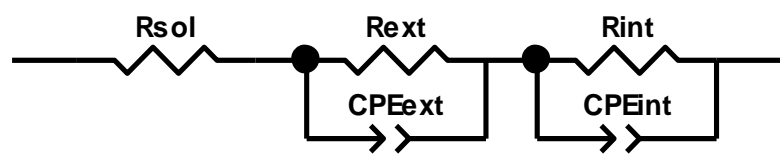

\begin{tabular}{|c|c|c|c|c|}
\hline Element & Freedom & Value & Error & Error \% \\
\hline Rsol & Free $(+)$ & 29,8 & 0,2413 & 0,80973 \\
\hline Rext & Free $(+)$ & 10028 & 975,65 & 9,7293 \\
\hline CPEext-T & Free $(+)$ & 4,2684E-05 & $2,6245 \mathrm{E}-06$ & 6,1487 \\
\hline CPEext-P & Fixed $(X)$ & 0,85841 & $\mathrm{~N} / \mathrm{A}$ & $\mathrm{N} / \mathrm{A}$ \\
\hline Rint & Free $(+)$ & $1,0609 \mathrm{E} 06$ & 56240 & 5,3012 \\
\hline CPEint-T & Free $(+)$ & 2,1482E-05 & $2,9806 \mathrm{E}-07$ & 1,3875 \\
\hline CPEint-P & Free $(+)$ & 0,85751 & 0,0039556 & 0,46129 \\
\hline \multicolumn{2}{|c|}{ Chi-Squared: } & \multicolumn{3}{|l|}{0,0041508} \\
\hline \multicolumn{2}{|c|}{ Weighted Sum of Squares: } & \multicolumn{3}{|l|}{0,56451} \\
\hline \multicolumn{2}{|c|}{ Data File: } & \multicolumn{3}{|c|}{ D:IMeus documentos\Mestrado\Resultados $\backslash$ EISIEIS' } \\
\hline \multicolumn{2}{|c|}{ Circuit Model File: } & \multicolumn{3}{|c|}{ D:IMeus documentos\MestradolResultados $\backslash$ EISIEIS } \\
\hline \multicolumn{2}{|c|}{ Mode: } & \multicolumn{3}{|c|}{ Run Fitting / Freq. Range $(0,001-1000000)$} \\
\hline \multicolumn{2}{|c|}{ Maximum Iterations: } & \multicolumn{3}{|c|}{100} \\
\hline \multicolumn{2}{|c|}{ Optimization Iterations: } & \multicolumn{3}{|l|}{0} \\
\hline \multicolumn{2}{|c|}{ Type of Fitting: } & \multicolumn{3}{|l|}{ Complex } \\
\hline \multicolumn{2}{|c|}{ Type of Weighting: } & \multicolumn{3}{|l|}{ Calc-Modulus } \\
\hline
\end{tabular}
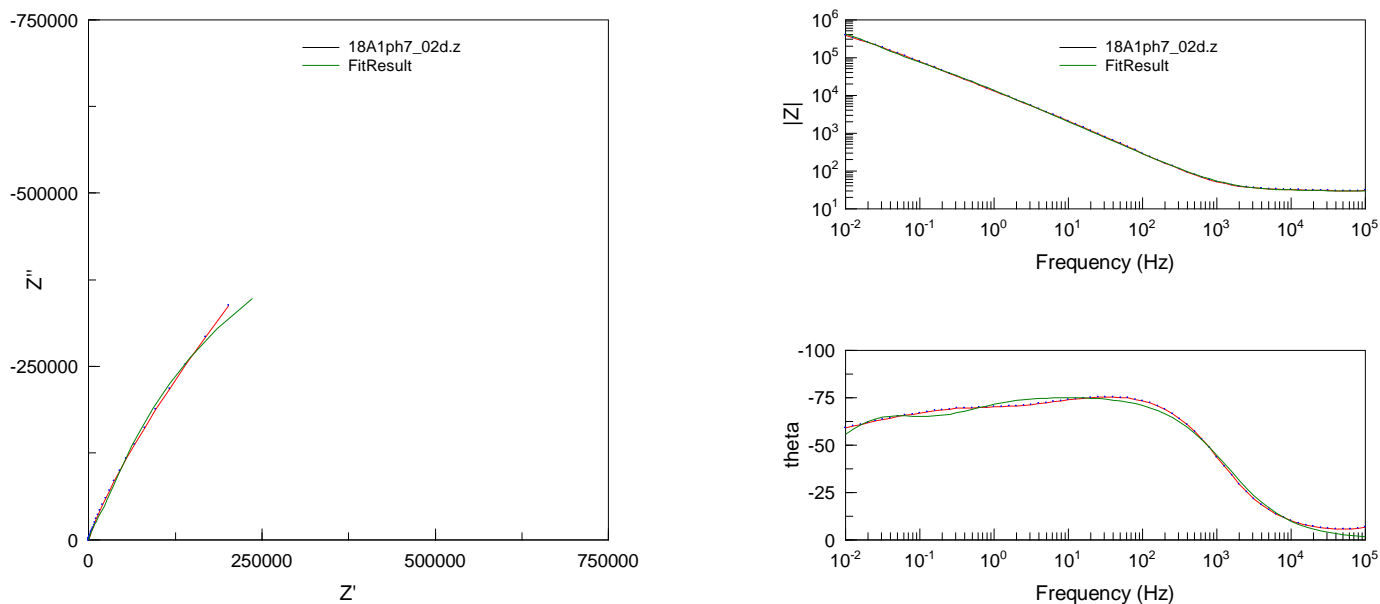

Ajustes dos diagramas de impedância pelo CEE para o aço 1802 após 2 dias de imersão em solução PBS a $25^{\circ} \mathrm{C}$. 


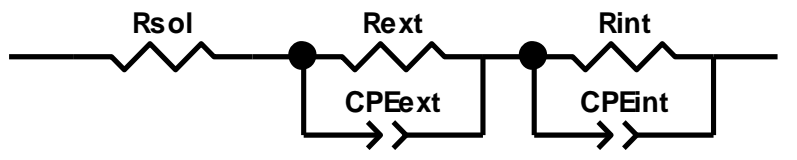

$\begin{array}{lllll}\text { Element } & \text { Freedom } & \text { Value } & \text { Error } & \text { Error \% } \\ \text { Rsol } & \text { Free }(+) & 30,9 & 0,16734 & 0,54155 \\ \text { Rext } & \text { Free }(+) & 5633 & 546,7 & 9,7053 \\ \text { CPEext-T } & \text { Free }(+) & 9,0163 \mathrm{E}-05 & 1,7995 \mathrm{E}-06 & 1,9958 \\ \text { CPEext-P } & \text { Fixed }(\mathrm{X}) & 0,80678 & \mathrm{~N} / \mathrm{A} & \mathrm{N} / \mathrm{A} \\ \text { Rint } & \text { Free }(+) & 1,6344 \mathrm{E} 06 & 99636 & 6,0962 \\ \text { CPEint-T } & \text { Free }(+) & 2,8228 \mathrm{E}-05 & 2,4198 \mathrm{E}-07 & 0,85723 \\ \text { CPEint-P } & \text { Fixed(X) } & 0,90223 & \mathrm{~N} / \mathrm{A} & \mathrm{N} / \mathrm{A}\end{array}$

Chi-Squared: $\quad 0,0029006$

Weighted Sum of Squares: $\quad 0,39738$

Data File: $\quad$ D:IMeus documentos\Mestrado\Resultados $\ E I S \backslash E I S$

Circuit Model File: $\quad$ D:IMeus documentos $\backslash$ Mestrado $\backslash$ Resultados $\backslash E I S \backslash E I S '$

Mode:

Run Fitting / Freq. Range (0,001 - 1000000)

Maximum Iterations:

100

Optimization Iterations: $\quad 0$

Type of Fitting:

Complex

Type of Weighting:

Calc-Modulus
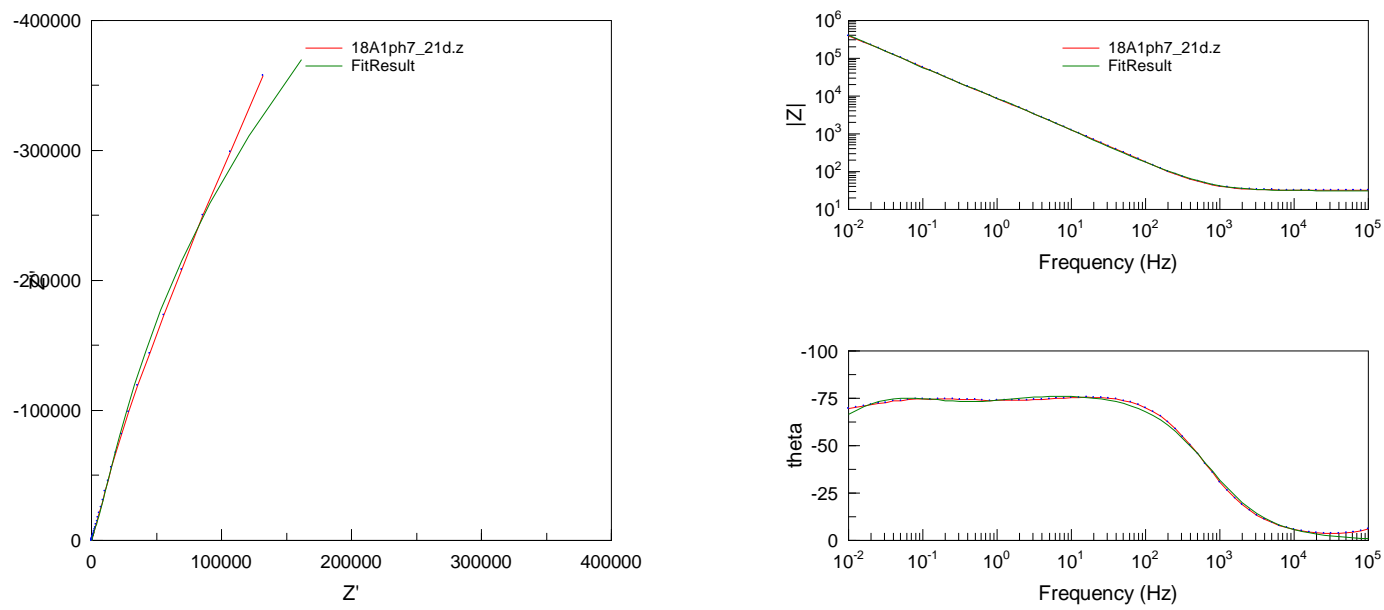

Ajustes dos diagramas de impedância pelo CEE para o aço 1802 após 21 dias de imersão em solução PBS a $25^{\circ} \mathrm{C}$. 


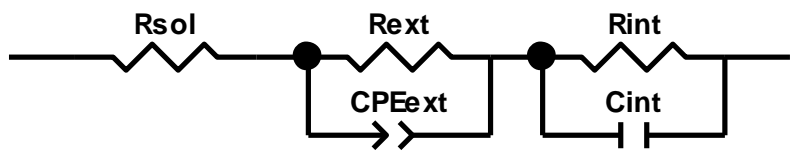

$\begin{array}{lllll}\text { Element } & \text { Freedom } & \text { Value } & \text { Error } & \text { Error \% } \\ \text { Rsol } & \text { Free(+) } & 16,15 & 0,081464 & 0,50442 \\ \text { Rext } & \text { Free }(+) & 24585 & 1779,3 & 7,2373 \\ \text { CPEext-T } & \text { Free(+) } & 0,00014697 & 2,6299 E-06 & 1,7894 \\ \text { CPEext-P } & \text { Free(+) } & 0,81845 & 0,0032032 & 0,39137 \\ \text { Rint } & \text { Free(+) } & 1,363 E 06 & 1,013 E 05 & 7,4321 \\ \text { Cint } & \text { Fixed }(\text { X }) & 5,6796 E-05 & \text { N/A } & \text { N/A }\end{array}$

Chi-Squared:

0,0036349

Weighted Sum of Squares:

0,49798

Data File:

D:IMeus documentos $\backslash$ Mestrado $\backslash$ Resultados $\backslash E I S \backslash E I S$

Circuit Model File:

D:IMeus documentos $\backslash$ Mestrado $\backslash$ Resultados $\backslash E I S \backslash E I S$

Mode:

Run Fitting / Freq. Range (0,001 - 1000000)

Maximum Iterations:

100

Optimization Iterations: $\quad 0$

Type of Fitting:

Complex

Type of Weighting:

Calc-Modulus
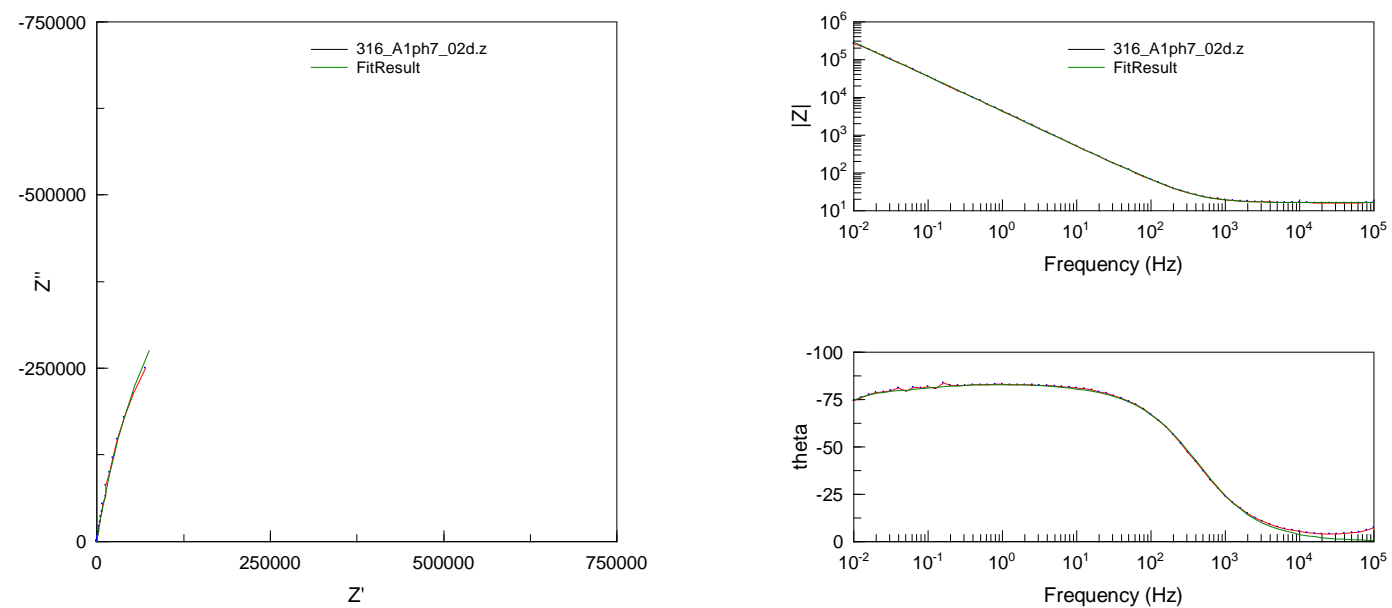

Ajustes dos diagramas de impedância pelo CEE para o aço 316L após 2 dias de imersão em solução PBS a $25^{\circ} \mathrm{C}$. 


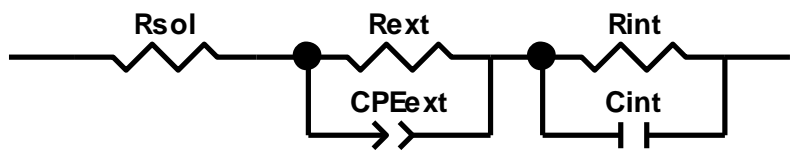

$\begin{array}{lllll}\text { Element } & \text { Freedom } & \text { Value } & \text { Error } & \text { Error \% } \\ \text { Rsol } & \text { Free(+) } & 16,2 & 0,074596 & 0,46047 \\ \text { Rext } & \text { Free(+) } & 25376 & 2187,7 & 8,6211 \\ \text { CPEext-T } & \text { Free(+) } & 0,00012844 & 2,4323 \mathrm{E}-06 & 1,8937 \\ \text { CPEext-P } & \text { Free }(+) & 0,8016 & 0,0031231 & 0,38961 \\ \text { Rint } & \text { Free }(+) & 3,423 E 06 & 3,2864 \mathrm{E} 05 & 9,6009 \\ \text { Cint } & \text { Fixed(X) } & 3,4669 \mathrm{E}-05 & \text { N/A } & \text { N/A }\end{array}$

Chi-Squared: $\quad 0,0028018$

Weighted Sum of Squares: $\quad 0,38384$

Data File: D:IMeus documentos\Mestrado\Resultados\EISIEIS

Circuit Model File: $\quad$ D:IMeus documentos $\backslash M e s t r a d o \backslash R e s u l t a d o s \backslash E I S \backslash E I S$

Mode:

Run Fitting / Freq. Range (0,001 - 1000000)

Maximum Iterations:

100

Optimization Iterations: $\quad 0$

Type of Fitting:

Complex

Type of Weighting: Calc-Modulus
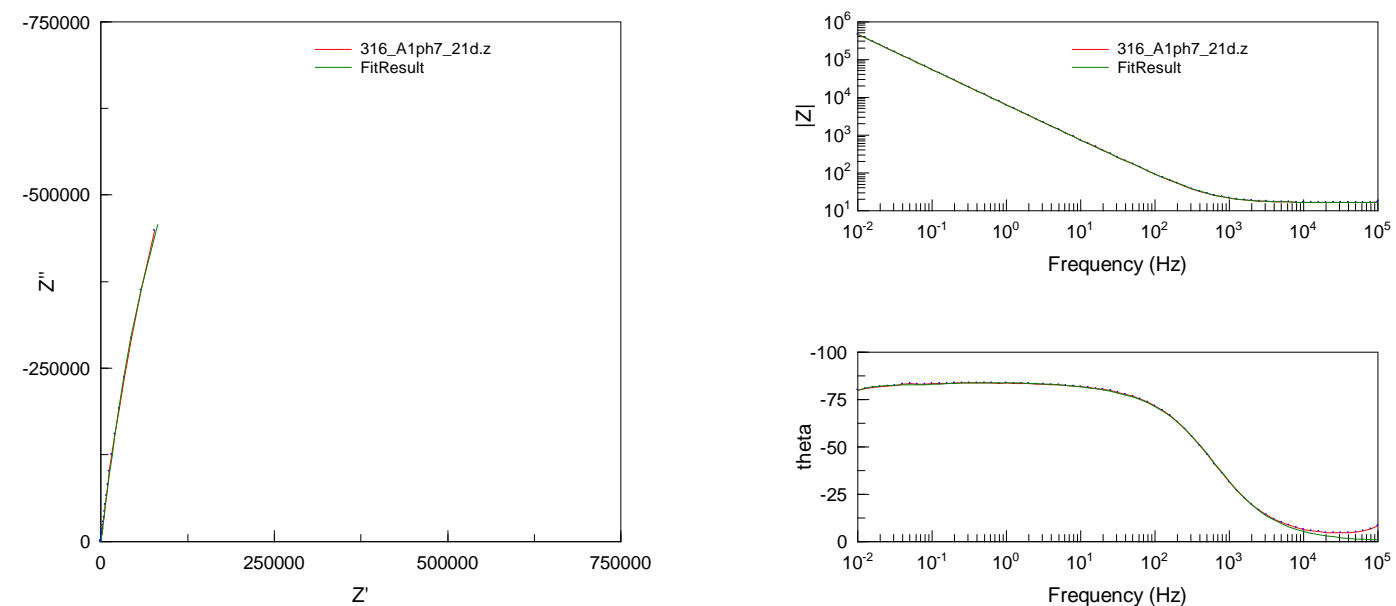

Ajustes dos diagramas de impedância pelo CEE para o aço 316L após 21 dias de imersão em solução PBS a $25^{\circ} \mathrm{C}$. 


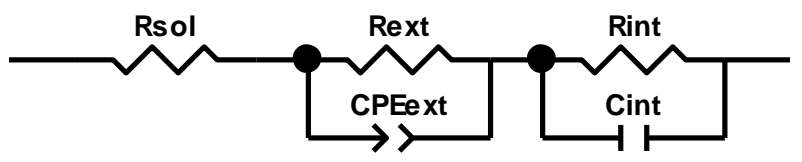

$\begin{array}{lllll}\text { Element } & \text { Freedom } & \text { Value } & \text { Error } & \text { Error \% } \\ \text { Rsol } & \text { Free }(+) & 11,55 & 0,106 & 0,91775 \\ \text { Rext } & \text { Free }(+) & 36038 & 3385,2 & 9,3934 \\ \text { CPEext-T } & \text { Free }(+) & 8,3095 \mathrm{E}-05 & 1,9692 \mathrm{E}-06 & 2,3698 \\ \text { CPEext-P } & \text { Free }(+) & 0,80108 & 0,003803 & 0,47473 \\ \text { Rint } & \text { Free }(+) & 1,5044 \mathrm{E} 06 & 1,3942 \mathrm{E} 05 & 9,2675 \\ \text { Cint } & \text { Fixed }(\mathrm{X}) & 3,9949 \mathrm{E}-05 & \text { N/A } & \text { N/A }\end{array}$

Chi-Squared: $\quad 0,0067362$

Weighted Sum of Squares: $\quad 0,92286$

Data File: $\quad$ D:IMeus documentos $\backslash M e s t r a d o \backslash R e s u l t a d o s \backslash E I S \backslash E I S$

Circuit Model File: $\quad$ D:IMeus documentos $\backslash$ Mestrado\Resultados $\backslash E I S \backslash E I S$

Mode: $\quad$ Run Fitting / Freq. Range $(0,001-1000000)$

Maximum Iterations: $\quad 100$

Optimization Iterations: $\quad 0$

Type of Fitting: Complex

Type of Weighting: Calc-Modulus
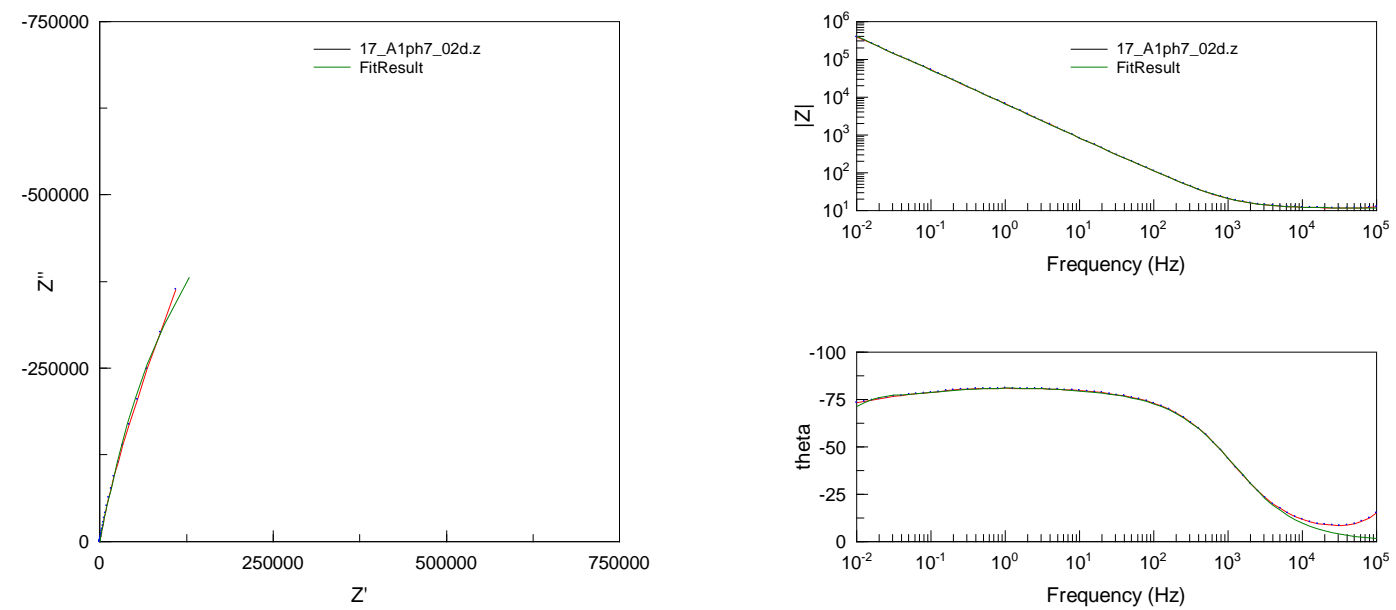

Ajustes dos diagramas de impedância pelo CEE para o aço 17-4PH PIM após 2 dias de imersão em solução PBS a $25^{\circ} \mathrm{C}$. 


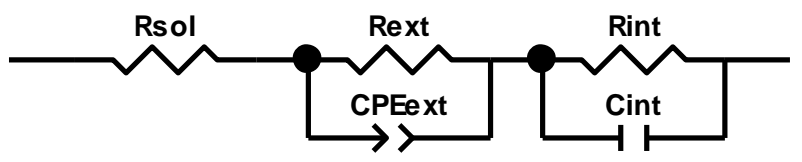

$\begin{array}{lllll}\text { Element } & \text { Freedom } & \text { Value } & \text { Error } & \text { Error \% } \\ \text { Rsol } & \text { Free }(+) & 11,78 & 0,078364 & 0,66523 \\ \text { Rext } & \text { Free }(+) & 35764 & 2307,1 & 6,4509 \\ \text { CPEext-T } & \text { Free }(+) & 6,6088 \mathrm{E}-05 & 1,1133 \mathrm{E}-06 & 1,6846 \\ \text { CPEext-P } & \text { Free }(+) & 0,79496 & 0,0026061 & 0,32783 \\ \text { Rint } & \text { Free }(+) & 2,9349 \mathrm{E} 06 & 2,789 \mathrm{E} 05 & 9,5029 \\ \text { Cint } & \text { Fixed }(\mathrm{X}) & 3,0768 \mathrm{E}-05 & \text { N/A } & \text { N/A }\end{array}$

Chi-Squared: $\quad 0,0031558$

Weighted Sum of Squares: $\quad 0,43234$

Data File: $\quad$ D:IMeus documentos $\backslash M e s t r a d o \backslash R e s u l t a d o s \backslash E I S \backslash E I S$

Circuit Model File: $\quad$ D:IMeus documentos $\backslash$ Mestrado\Resultados $\backslash E I S \backslash E I S$

Mode: $\quad$ Run Fitting / Freq. Range $(0,001-1000000)$

Maximum Iterations: $\quad 100$

Optimization Iterations: $\quad 0$

Type of Fitting: Complex

Type of Weighting: Calc-Modulus
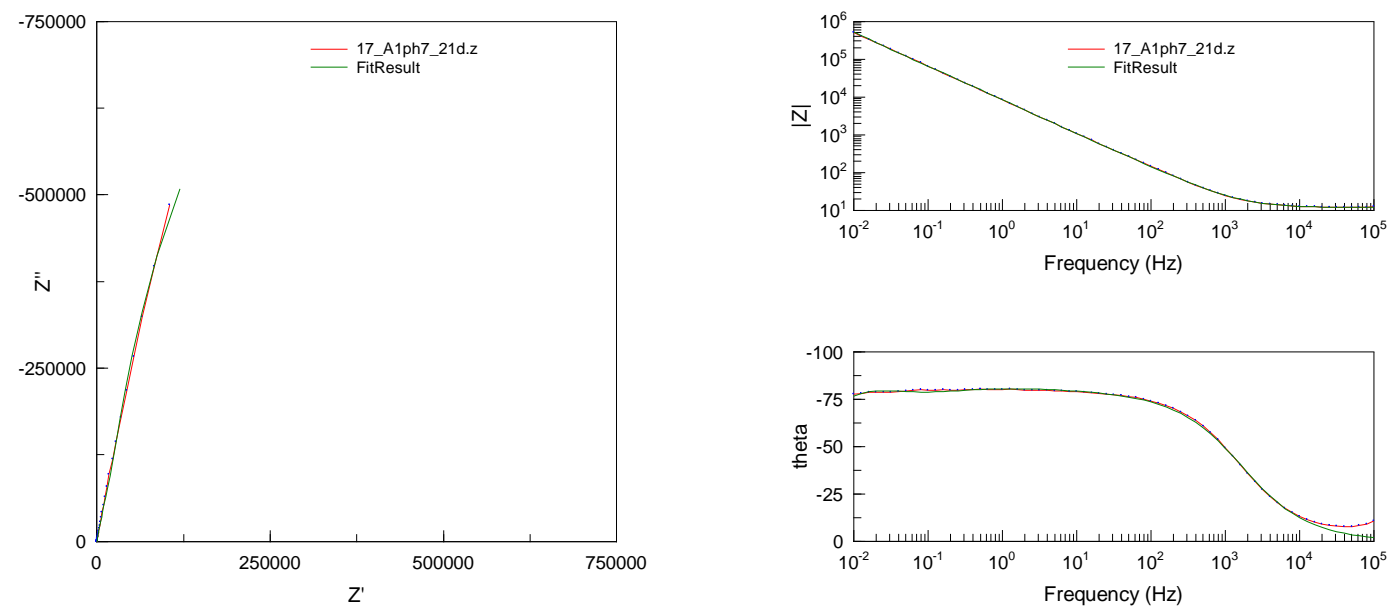

Ajustes dos diagramas de impedância pelo CEE para o aço 17-4PH PIM após 21 dias de imersão em solução PBS a $25^{\circ} \mathrm{C}$. 


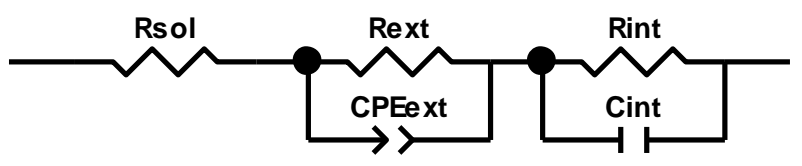

$\begin{array}{lllll}\text { Element } & \text { Freedom } & \text { Value } & \text { Error } & \text { Error \% } \\ \text { Rsol } & \text { Free }(+) & 12,5 & 0,077595 & 0,62076 \\ \text { Rext } & \text { Free }(+) & 43120 & 2861,2 & 6,6354 \\ \text { CPEext-T } & \text { Free }(+) & 7,0715 \mathrm{E}-05 & 1,0864 \mathrm{E}-06 & 1,5363 \\ \text { CPEext-P } & \text { Free }(+) & 0,78309 & 0,002389 & 0,30507 \\ \text { Rint } & \text { Free }(+) & 3,1776 \mathrm{E} 06 & 3,1891 \mathrm{E} 05 & 10,036 \\ \text { Cint } & \text { Fixed }(\mathrm{X}) & 3,2063 \mathrm{E}-05 & \text { N/A } & \text { N/A }\end{array}$

Chi-Squared:

0,0027144

Weighted Sum of Squares: $\quad 0,37188$

Data File:

D:IMeus documentos $\backslash$ Mestrado\Resultados $\backslash E I S \backslash E I S$

Circuit Model File:

D:IMeus documentos $\backslash$ Mestrado\Resultados $\backslash E I S \backslash E I S$

Mode:

Run Fitting / Freq. Range (0,001 - 1000000)

Maximum Iterations:

100

Optimization Iterations:

Type of Fitting:

0

Type of Weighting:

Complex

Calc-Modulus
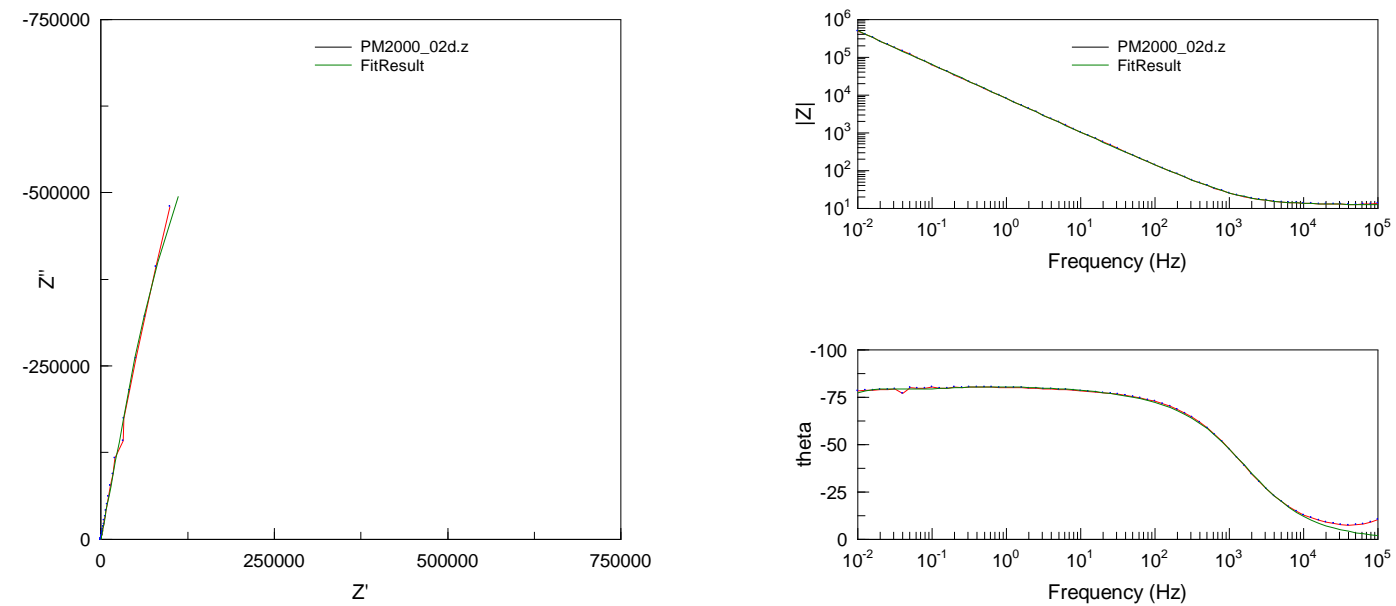

Ajustes dos diagramas de impedância pelo CEE para o aço PM2000 após 2 dias de imersão em solução PBS a $25^{\circ} \mathrm{C}$. 


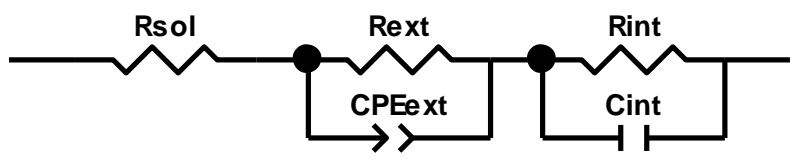

$\begin{array}{lllll}\text { Element } & \text { Freedom } & \text { Value } & \text { Error } & \text { Error \% } \\ \text { Rsol } & \text { Free }(+) & 15,28 & 0,13651 & 0,89339 \\ \text { Rext } & \text { Free(+) } & 18397 & 2014,2 & 10,949 \\ \text { CPEext-T } & \text { Free(+) } & 7,991 \mathrm{E}-05 & 2,2704 \mathrm{E}-06 & 2,8412 \\ \text { CPEext-P } & \text { Free }(+) & 0,7545 & 0,0042582 & 0,56437 \\ \text { Rint } & \text { Free(+) } & 5,136 E 06 & 9,2367 \mathrm{E} 05 & 17,984 \\ \text { Cint } & \text { Fixed }(X) & 2,6033 \mathrm{E}-05 & \text { N/A } & \text { N/A }\end{array}$

Chi-Squared:

0,0057559

Weighted Sum of Squares:

0,77704

Data File:

D:IMeus documentos $\backslash$ Mestrado|Resultados $\backslash E I S \backslash E I S$

Circuit Model File:

D:IMeus documentos $\backslash$ Mestrado|Resultados $\backslash E I S \backslash E I S$

Mode:

Run Fitting / Freq. Range (0,001 - 1000000)

Maximum Iterations:

100

Optimization Iterations:

0

Type of Fitting:

Complex

Type of Weighting:

Calc-Modulus
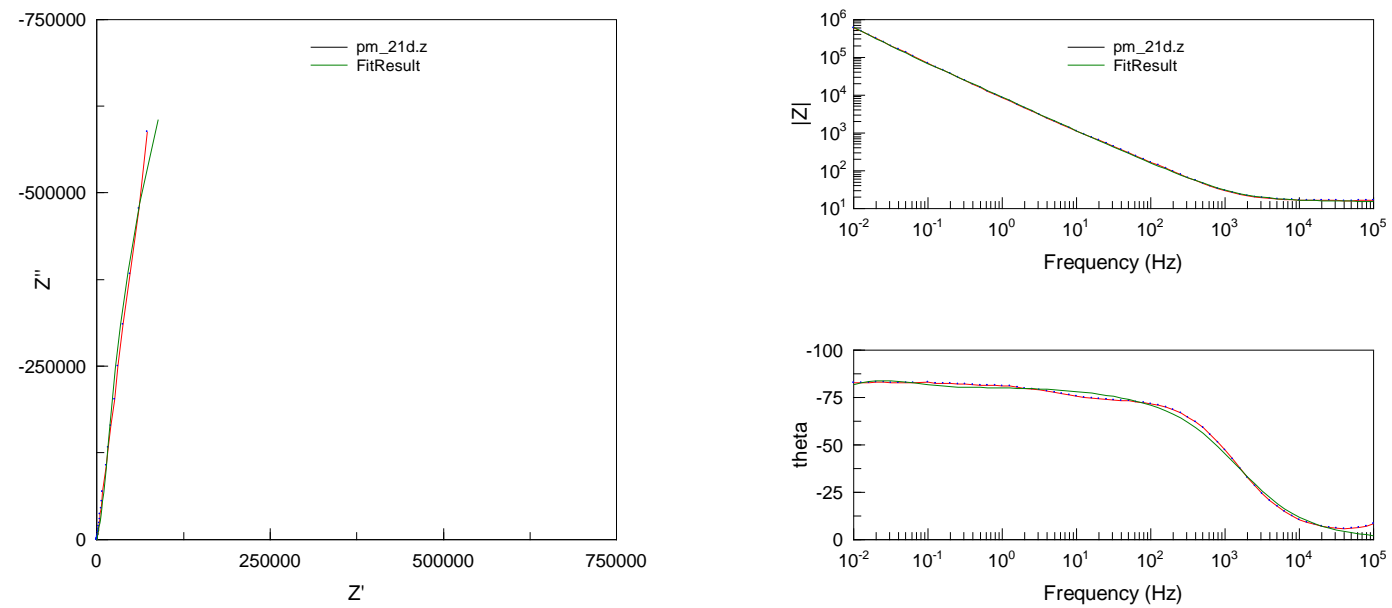

Ajustes dos diagramas de impedância pelo CEE para o aço PM2000 após 21 dias de imersão em solução PBS a $25^{\circ} \mathrm{C}$. 